Historic, Archive Document

Do not assume content reflects current scientific knowledge, policies, or practices. 



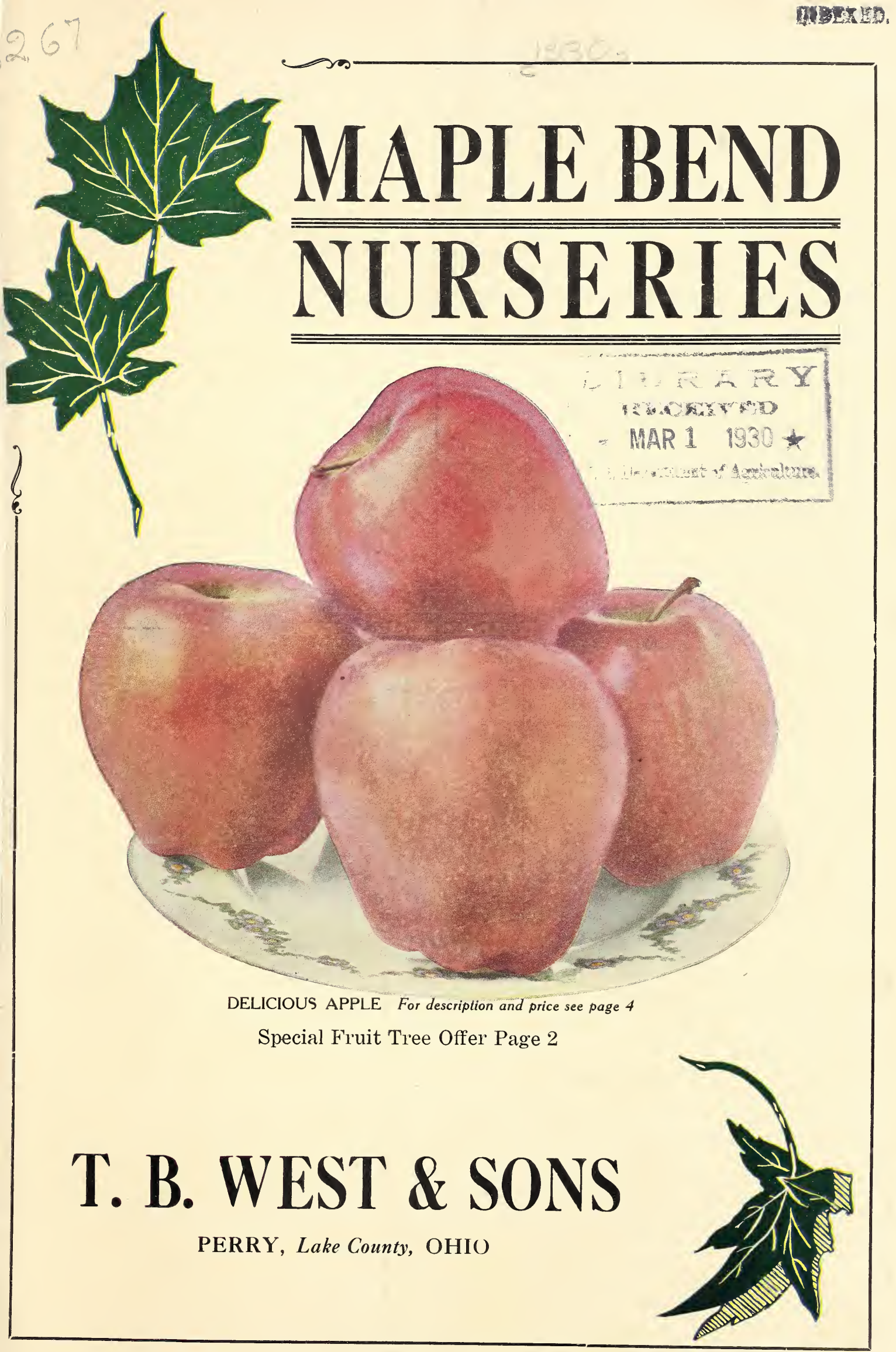




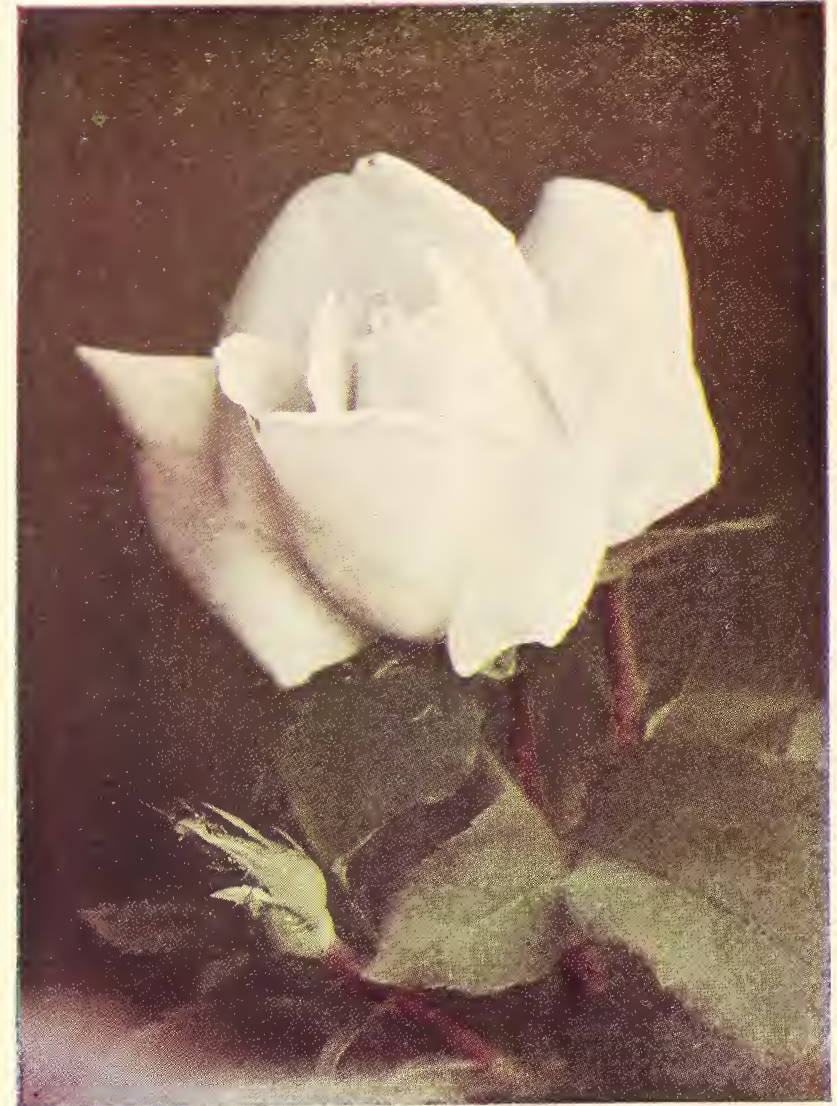

ROSE FRAU INARL DRUSCHKI

\section{SHRUB SPECIAL} Special Offer "B"

From early Spring until late November you will have a continuous succession of bloom from these choice shrubs.
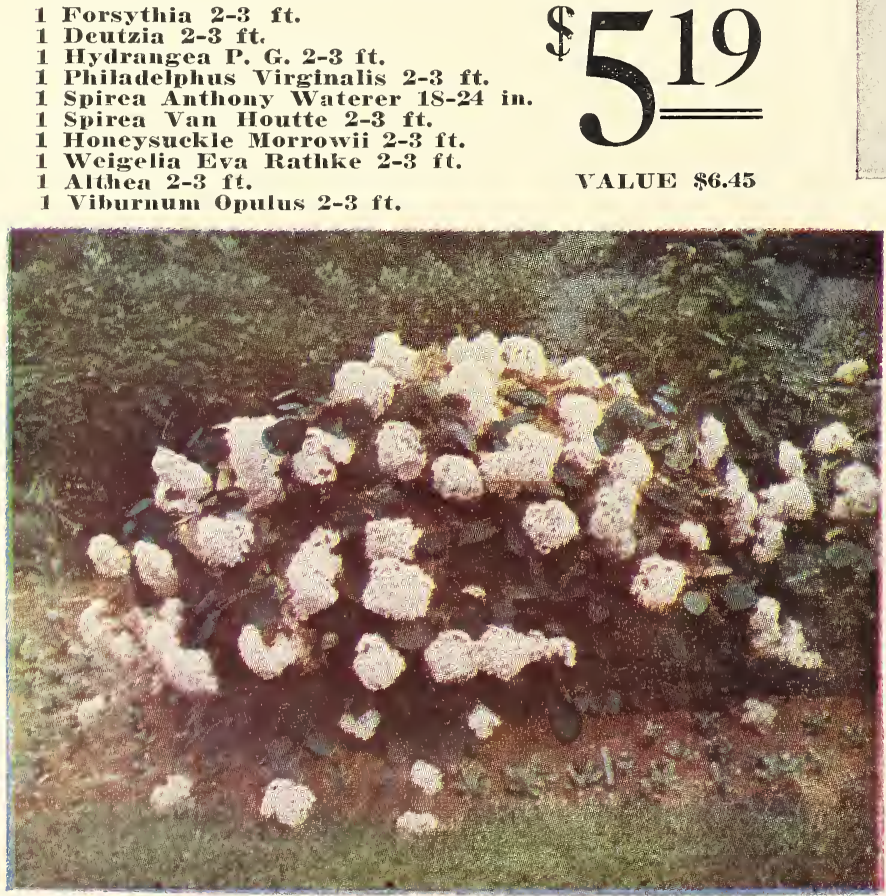

\section{Rose Special}

\section{Special Offer "A"}

These three Hybrid Perpetuals and three Hybrid Teas represent our most popular rose varieties. Budded on seedling roses. A real bargain.
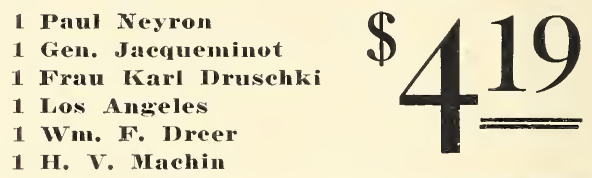

VALUE $\$ 5.25$

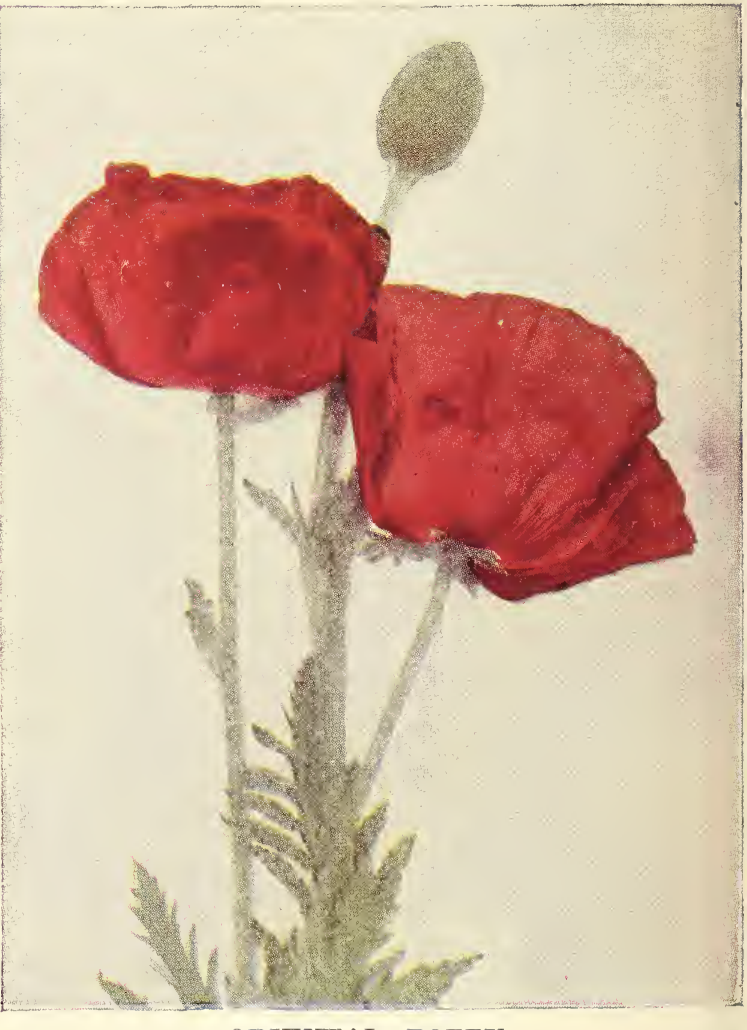

ORIENTAL POPPY

\section{Hardy Plant Special Special Offer "C"}

Flowers from early May until late fall is the reward of your care of these plants. A real bargain to brighten the lawn and garden.

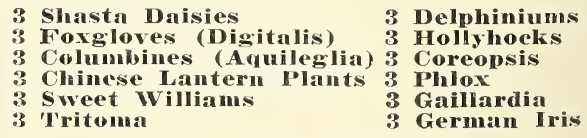

3 Sweet

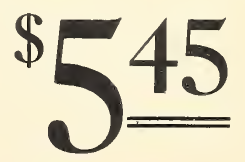

VALUE $\$ 7.20$ 

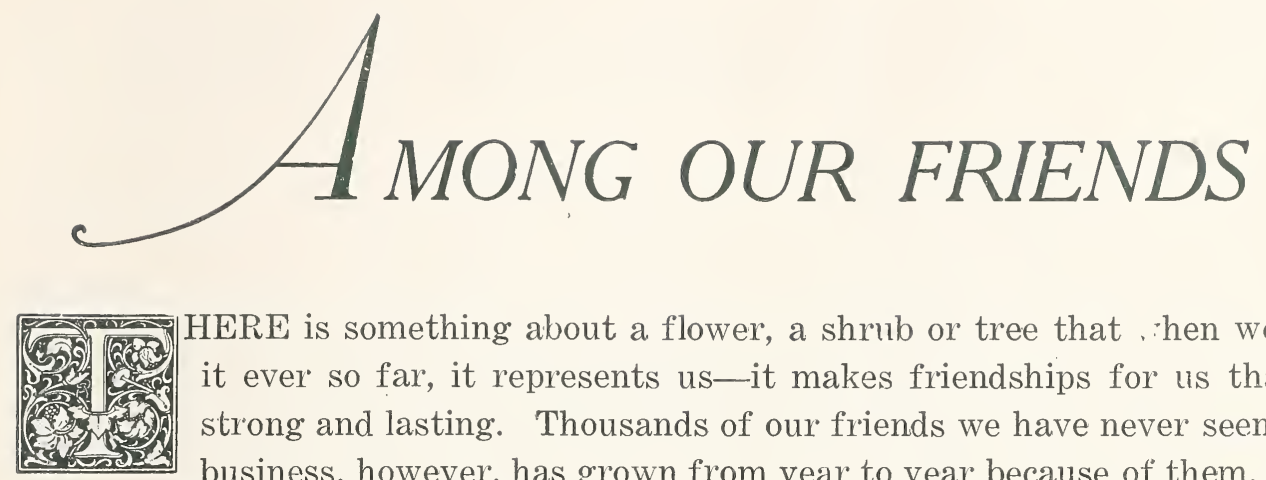

HERE is something about a flower, a shrub or tree that , then we send it ever so far, it represents us-it makes friendships for us that are strong and lasting. Thousands of our friends we have never seen. Our business, however, has grown from year to year because of them. Since 1893 this friend-making has developed to a degree that is pleasant to say the least.

We appreciate the kind words people have said about us and our nursery stock and we shall always try to merit this kindness by supplying the best, the most thrifty plants and shrubs and trees in filling orders.

Our soil and climate are eminently adapted to the production of hardy trees and shrubs. Tempered by Lake Erie, our climate has a tendency to ripen and harden growing things wonderfully well.

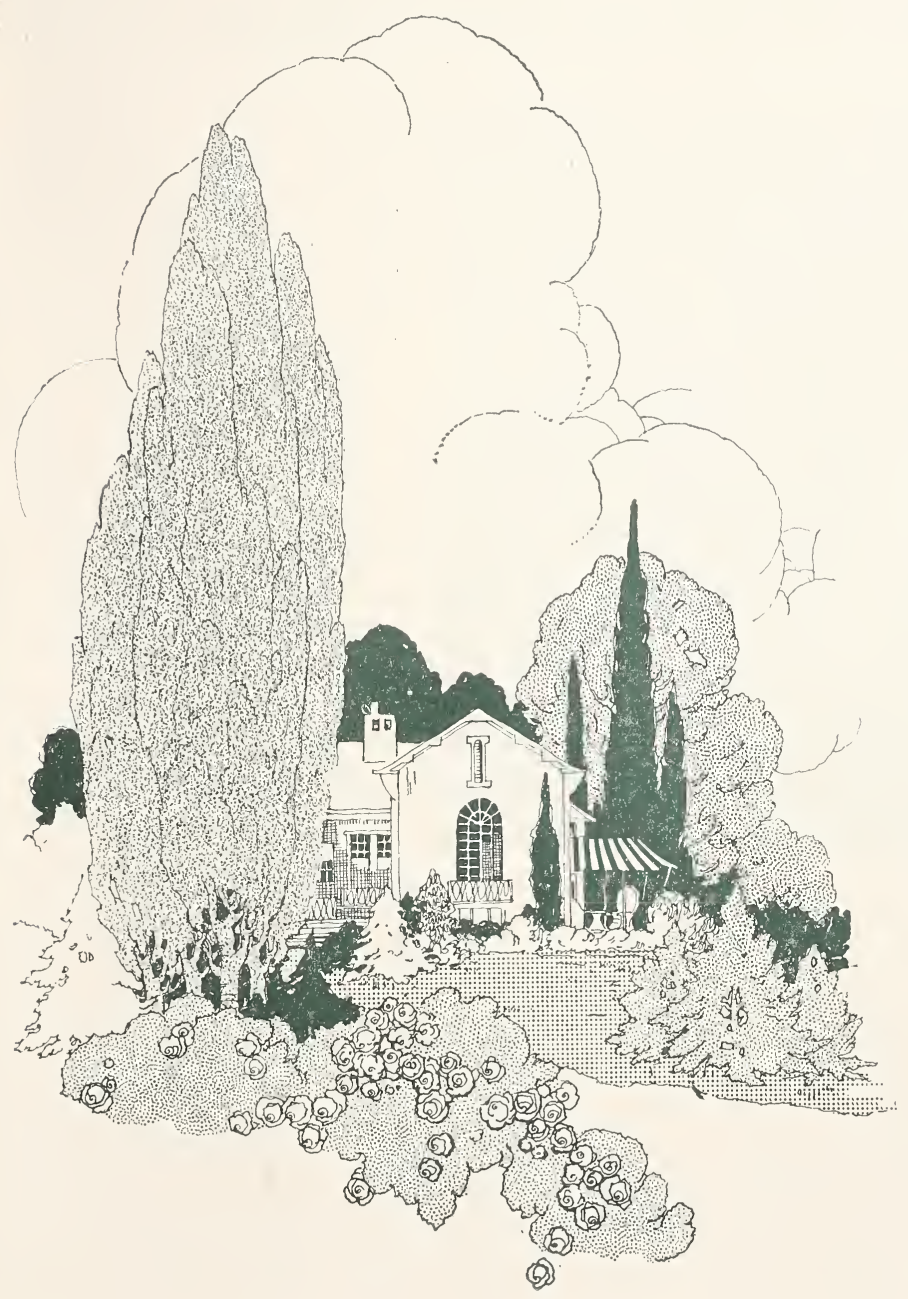

By growing $\mathrm{nur}$ s e ry stock for a wholesale as well as a ritail business we are able to supply large quantities at considerably lower prices. Send your larger lists for specia! discounts from the prices quoted herein. Quality consiaered, we think our prices ai'e very reasonable.

The order blank and eivelope in the back are for your convenience and it saves our time if you use them. We can serve you better if you order early. All orders are filled in rotation.

If you are not acquainted with us you do not know how far we will go to make a new friend. We will go still farther to keep an old one. An order will convince you.

\section{Maple Bend Nurseries}

T. B. WEST \& SONS

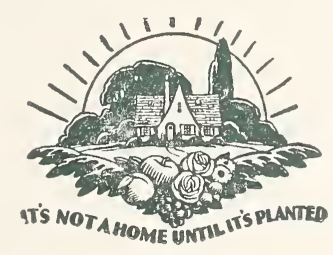




\section{Plant for Beauty and Utility}

$\mathbf{W}_{\text {thou san and }}^{\text {E w that }}$ there is nothing which so adds to home attractions as a frame of flowers and shrubs. A decorated lawn, an infor- aal garden, an outdoor living room, shade trees, vines, roses and perennial plants all have a share. in the scheme of beautification. The most barren spots take on new life and beauty when well planted. But there is another side of life.

Home fruit is the sat. isfying possibility that presents itself to every home owner with space for it. It doesn't take much room for a planting
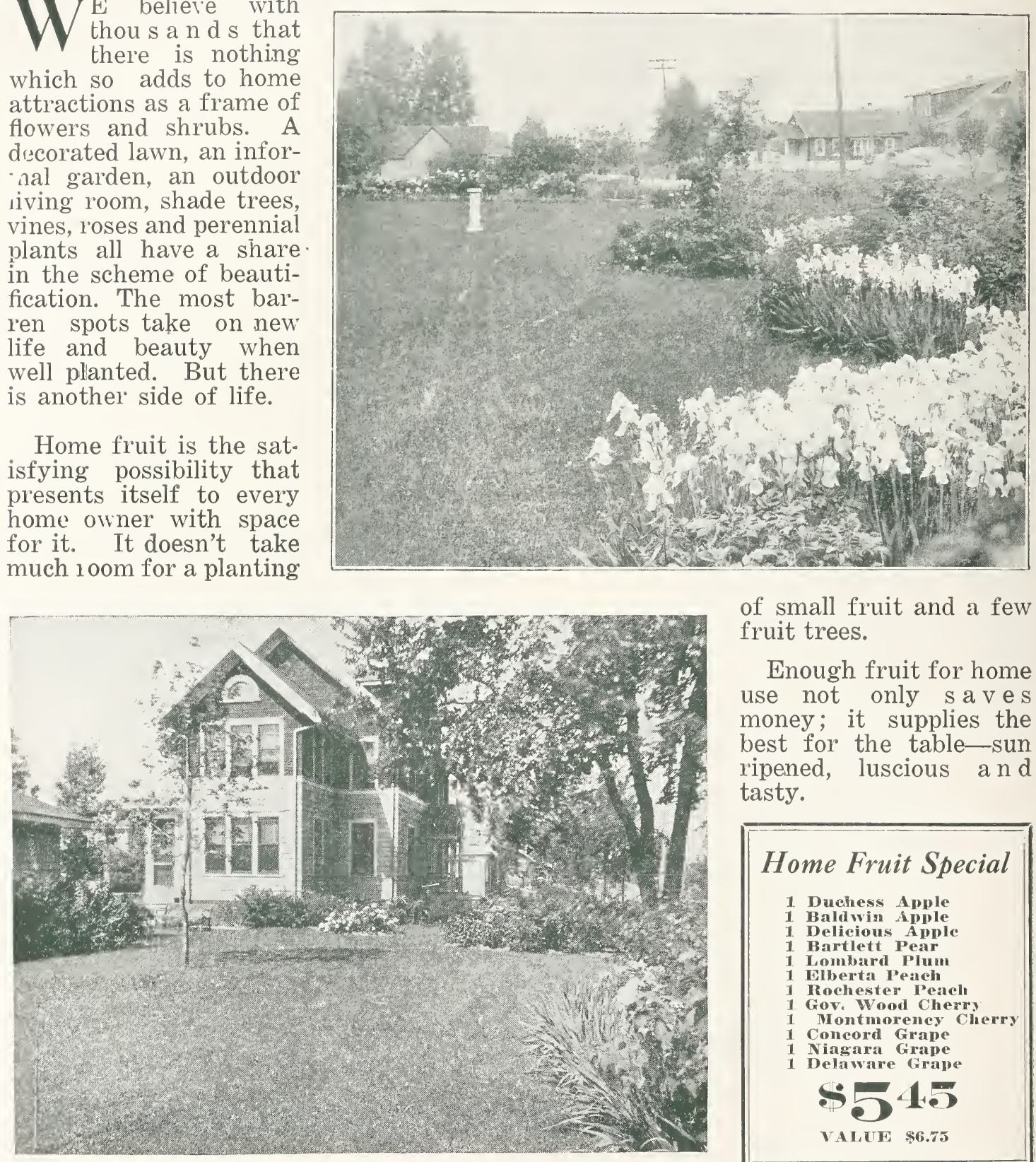

of small fruit and a few fruit trees.

Enough fruit for home use not only saves money; it supplies the best for the table-sun ripened, luscious and tasty.

\section{Home Fruit Special \\ 1 Duahess Apple \\ 1. Baldwin Apple \\ 1. Delicious Apple \\ 1. Bartlett Pear \\ 1 Lombard Plum \\ 1 Elberta Peach \\ I Rochester Peach \\ 1 Gov. Wood Cherry \\ I Montmorency Cherry \\ 1 Concord Grape \\ 1 Niagara Grape \\ 1 Delaware Grape \\ $\prod_{0}$ He \\ VALUE $\$ 6.75$}

\section{INDEX}

\begin{tabular}{|c|c|c|}
\hline Summer & Page & Fruit Special \\
\hline Apples, Fall ... & $\ldots, 4$ & Gooseberries \\
\hline pples, Winter & & Grasses, Ornamental \\
\hline pples, Crab. & & Grapes, Red ........ \\
\hline ricots $\cdots$ & & Grapes, White \\
\hline $\begin{array}{l}\text { Asparagus } \\
\text { Blackberries }\end{array}$ & & $\begin{array}{l}\text { Grapes, Black } \ldots . . \\
\text { Hardy Plants } \ldots . .\end{array}$ \\
\hline herries, Sweet & & Hedges \\
\hline herries, Sour & & Inside \\
\hline urrants, Red & & Mulberries \\
\hline Deciduous Trees & & Ornamental Dept. \\
\hline Dewberries & $\ldots$ & Peaches \\
\hline vergreens ..... & $\ldots$ & Plums, E \\
\hline
\end{tabular}

Plums, Japanese

Pears, Winter

Pears, Summer

Pears, Autumn ...... 7-8

Plants, Perennial .29-3

Peonies Inside Bk. Cov

Location Inside Bk. Cov.

Quinces

Rhubarb

Raspberries, Purple

Raspberries, Black ..12

Raspberries, Red .12-13 age

Tespor 12 Roses, Perpetual …25 Roses, Hybrid Tea ..26 Roses, Polyantha ....27 Roses, Climbing .....2 Strawberries .....13-14 Strawberries, EverbearTerms Inside Bk. Cover Trees, Deciduous .16-18 Trees, Weeping …18 


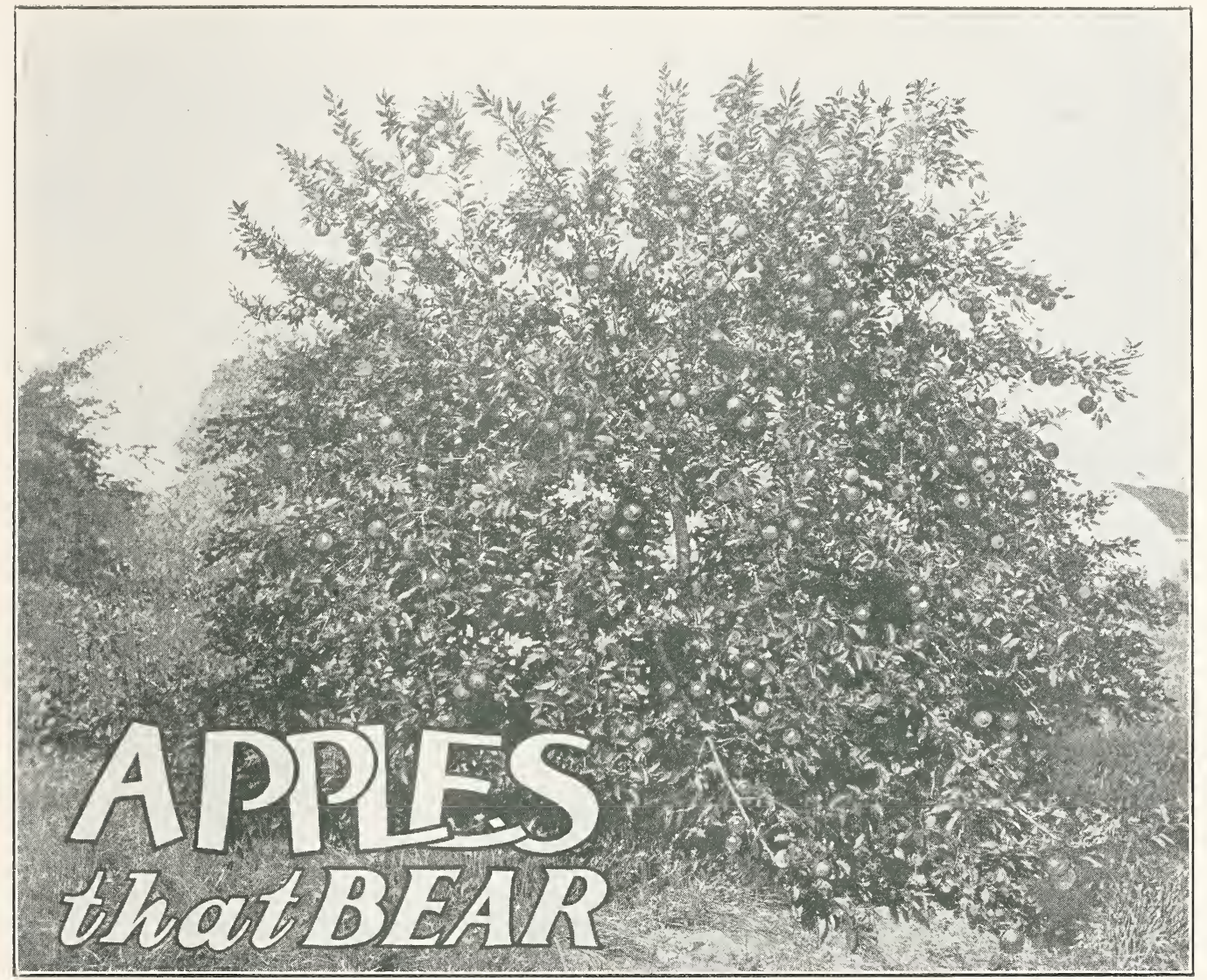

The above tree is a 9-year-old Delicious on our Nursery. In 1927 it bore 7 bushels of apples. In 1928 it had $51 / 2$ bushels, but they were better quality than the year before. Last fall it had a good crop altho the fruit was not accurately measured.

\section{Apple Trees}

GOOD apple orchard is a wonderful source of income for any farmer. Per acre of ground it will undoubtedly produce more profit than any other crop you - can raise. The market demand for good apples is constantly increasing and at
very profitable prices. An orchard planted now will be a winner in ten years and will pay its way long before that if given proper care.

A good orchard is like insurance to many a farmer who has spent his best years in hard work. The orchard produces good crops with a minimum of work and the use of the land for the few years it took to grow it will never be missed.

When planting an orchard it should be borne in mind that the planter is making a long time investment that will pay several hundred percent dividends in years to come.

\section{SUMMER VARIETIES}

B carefully choosing varieties with your mar. ket in mind, large quantities of early apples are easily disposed of along with other fruit and vegetables in July and August.

EARLY HAIREST. Fruit is medium size to large: the skin tender, very smooth, clear pale waxen yellow. Sub-acid. July.

GOLIDEN SWEET. Rather large. Pale yellow. One of the best sweet apples. August.

RED ASTKACHAN. * Deep crimson sometimes striped with yellowish green; medium to large in size, tender, tart. For nearby markets one of the most profitable apples. Last of July to
the middle of August. SWEET BoUGH. Large yellow, sugar sweet.
Hardy.
YELLOW TRANSPARENT, * One of the best known summer apples. Often bears the second year after planting. Pale yellow, pleasantly acid, tender and good.

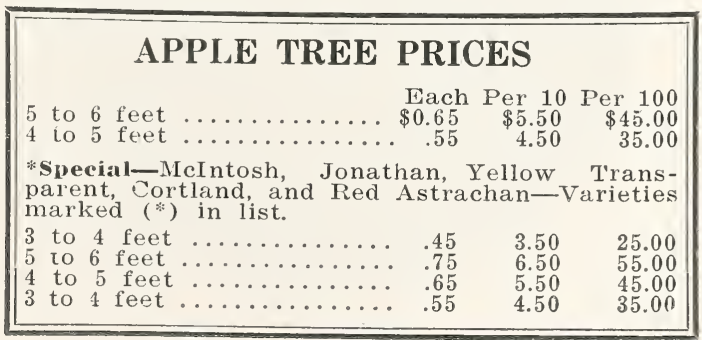




\section{FALL VARIETIES}

CHENA YGO STRAWBERIRY. Large be a u i i u 1 fruit yellowish-white striped with red, excellent quality, carly and regular bearer. September to Novembel.

FALL PIPPIN. Large beautiful yellow, rich and tender. September to December.

GRAVENSTEIN. Greenish yellow striped with red. Highly flavored. Valuable for market and cooking. September to November.

MAIDEN BLUSH. Creamy yellow flushed with red. September and October.

MINSON SWEET. Pale yellow, often somewhat blushed. October and November.

OLDENBIRG. (Duchess of Oldenburg.) Yellow striped and mottled with red. Thrifty and does well in nearly all sections, comes into bearing. the third year after planting. The trees are naturally dwarf growers and make fine fillers. Late August and September.

RAMBO. A fine well known red variety. Late fall.

\section{WINTER VARIETIES}

BALIWIN. One of the best known market varieties of the northern states. In the territory north of Columbus, Ohio, through Pennsylvania, New York, Michigan, Northern Indiana, and the New England states. it is the leading market variety. It is olle of the most reliable of the old sorts. Large, deep red, crisp, juicy flesh, good flavor.

BANANA. $\Lambda$ very early and annual bearer. Beautiful golden yellow. One of tlie most successful of the winter varieties, and should be included in every collection. Flesh sweet, tender and juicy.

DELICIOUS. Large, oblong, brilliant dark red, with fine-grained, juicy crisp and melting flesh. Hardy, and an early and productive bearer. One of the best new varieties, which has been successfully grown in most every section of the country.

FALI.AWATEIR. Large, with smooth skin of a yellowish green, with a dull red cheek. Flesh white, crisp and juicy. Tree a fast grower and productive. Sometimes known as the Tulpehocken.

FAMEUSE. (Snow.) Medium size, deep crimson, snowy white, tender, melting flesh of fine flavor.

GOLIEN RUSSF'T. Fruit medium, golden russet, with bronze cheek. Tree hardy and a reliable cropper. December to April.

GRIMES. Good size, yellow, slightly russeted, juicy, rich, good keeper retaining its crispness and flavor. One of the best winter apples.

HUHBARDSTON. Large, handsome, yellow, overlaid with red; tender flesh, delicious flavor. Hardy and productive.

JONATHAN. * Medium size, pale yellow heavily overlaid with red; flesh whitish, tender, crisp, juicy, slightly sub-acid. A fine keeper.

KING. Tery large, red, fair quality, very productive, flesh is slightly coarse but tender and vinous.

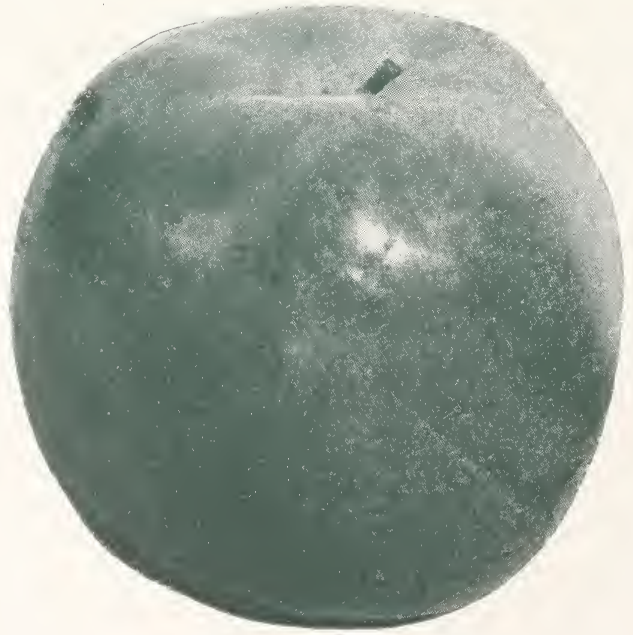

Jonathan

\section{COURTLAND*}

A NEW variety developed from the McIntosh and superior to it. The fruit is as large or larger than the McIntosh, round or slightly conical in shape. Courtland apples are a bright luscious red that appeals so strongly to people. The flesh is white, firm, fine grained, crisp and tender. They are very juicy with a delightful sub-acid flavor. The trees bear quickly - the third and fourth year after plantinga money crop the sixth year. The apples hang on the tree unusually well, has a long picking season-easy to handle and pack. Do not bruise easily and reach the consumer in perfect condition.

MeINTOSH. Goed size, yellow washed and deeply blushed with bright red; flesh white tender crisp, iuicy, slightly sub-acid becoming mild and nearly sweet when ripe.

MELBA. McIntosh type. Red striped apple which resembles McIntosh in aroma flesh and flavor but not in color, shape and general appearance.

NORTHERN SPY. One of the oldest and best known varieties. Large, pale yellow ground nearly covered with bright red; effect bright red or striped red, flesh yellowish, tender, crisp. juicy and sub-acid. Tree hardy and strong growing.

NOR'HWWE'TERN. Medium to large; clear pale yellowish or greenish yellow; flesh yellowish, mild sub-acid, juicy. A good hardy variety.

PUMPIsIN sWEE'T. Fruit large to very large narbled with light and dark green; streaked marbled. With light and dark green; streaked
with whitish scarf-skin. Tree strong grower and long lived. October to January.

ROME BEAU'Y. Has been the best monev maker of any apple through southern ohio, Pennsylvania, New York and West Virginia. Medium to large size; golden yellow ground, mottled and large size; golden yellow ground, mottled ind
overlaid with red. Flesh nearly white, firm, crisp, juicy, mild, sub-acid.

IR. I. GIREENING. Large, greenish yellow, fine quality, the best for culinary purposes, The tree bears regularly and profusely.

STARK. Large, greenish yellow, striped witl red. Flesh is yellow, moderately juicy, mild, sub-acid. Vigorous.

STAYMAN. Of high quality, annual and prolific bearer, medium to large size, red and yellow ground. One of the finest apples for fancy trade when properly grown.

SUTTON. A desirable market variety. Medium to large, bright red nearly overspreading the yellow ground; flesh crisp, tender, mild sub-acid

TOLMAN. Medium size; pale yellow s 1 ig h t ly tinged with red, firm, rich and sweet; excellen for baking.

TWENTY-OUNCE. Very large and handsome, washed, mottled and splashed with bright red flesh coarse, juicy and sub-acid.

WAGENER. One of the best apples for this northern section. Medium to large, sinooth. glossy, pinkish-red striped with bright carmine on a pale yellow ground; crisp, tender, juicy, sub-acid; very good.

WEAL'TH: Large, yellow, blushed and striped with red: effect very bright red. Flesh, crisp, tender, very juicy and very good. Early, regular and ibundant bearer.

YORK IMPEIRIA A very important conmercial variety. Does well everywhere. Medium size yellow or green blushed with light red or pinkish yellow or green blushed with light red
red. Flesh firm, crisp, mild sub-acid.

The Mann orcherd owned by the Grand River Orchard Co. south of Unionville was planted in 1915 ard has had a crop on it every year since it was four years old. They harvested about 30,000 bushels in 1929 when others had limited crops, and the income from the orchard that year was a recordbreaker. 


\section{CRAB APPLES}

HYSIOP, Large deep red fruit, that hangs thickly in clusters.

TRANSCENDEN'T: Large, golden yellow striped with red; excellent for culinary use; very productive.

WHITNEY. Large, smooth, glossy green,' heavily striped with carmine. Tree hardy, vigorous and heavy bearer.

\section{ABOUT APPLE TREES}

Most good farm land will grow orchards if given intelligent management. The Farnsworth Bros. of Waterville, Ohio, were ridiculed for their choice of location and the soil chosen for their orchards. Yet their success has been recognized for years as one of the most outstanding of any orchard proposition in the state of Ohio.

With good care and good soil, the following varieties will come into bearing from 3 to 5 years from planting:

Yellow Transparent, Oldenberg, Rome Beauty, Grimes, Wagener, Wealthy, McIntosh, Maiden Blush, Stayman, Gravenstein, Banana, Delicious, Gano, Northwestern, Stark, Jonathan, and York Imperial.

Early Harvest, Red Astrachan, Sweet Bough, Golden Sweet, Baldwin, Hubbardston, Northern Spy, and R. I. Greening. Of course this does not complete the entire list of varieties we offer, but it will be a guide to those wishing to plant.

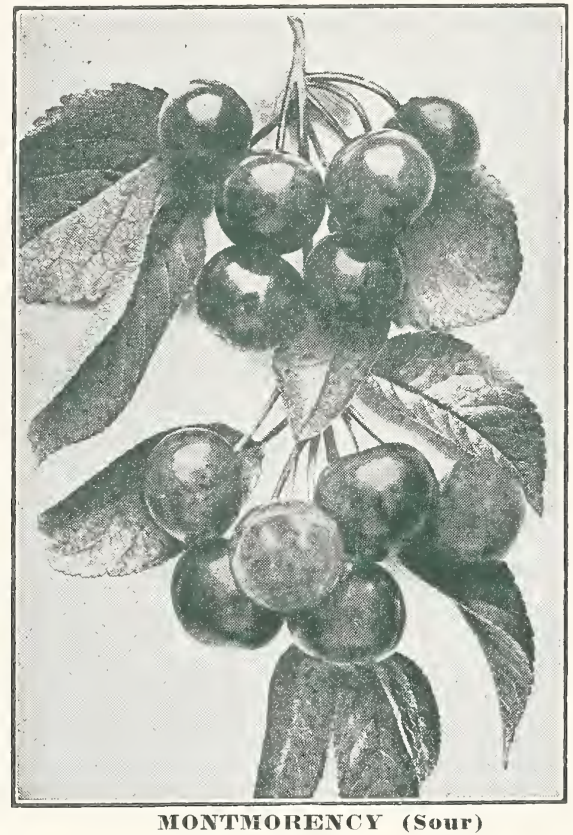

\section{Cherries}

CHERRIES need no recommendation either for home supply plantings or for commercial orchards. The demand for good cherries never lags. Cherry trees do best in a warm gravely soil, well drained. Plant sour cherries 16 to 18 feet each way and sweet cherries 20 to 25 feet each way.

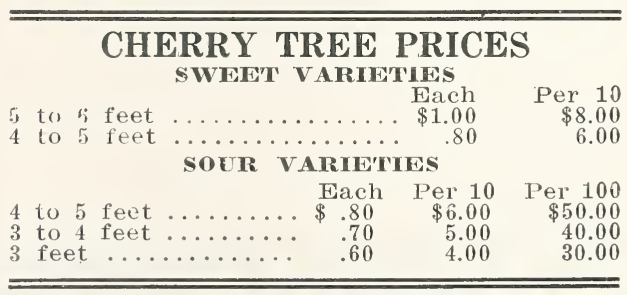

\section{SWEET VARIETIES}

BING. Very large, very dark red, almost black flesh, purplish red, firm, sweet, very good quality. Mid-season to later.

LAMBERT. Very large, dark red, changing to reddish black; flesh dark red, meaty, firm and sweet, good quality. Hardy and productive. Mid-season.

NAPOLEON. Large, bright red over yellow background; flesh whitish, with yellow tinge, tender, meaty, crisp and sweet. Mid-season.

SCHMID' Purplish black; flesh purplish red, dark colored, juicy, crisp, firm, sweet, good quality. Large Mid-season.

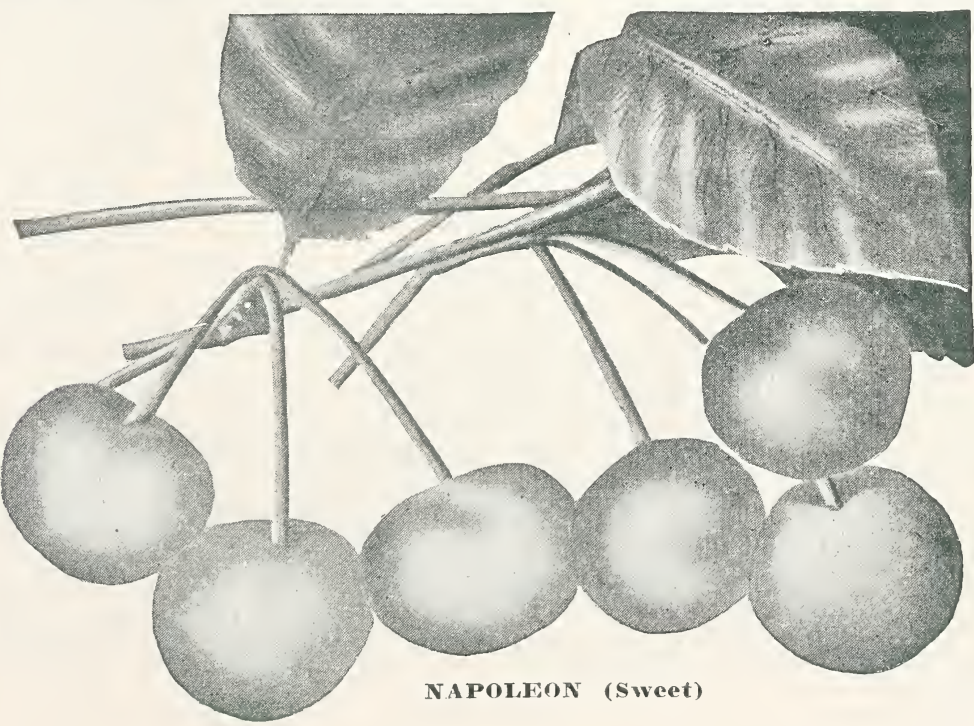

SPANISH. Bright amber yellow with red blush; flesh whitish, tender, crisp, sweet, very good. Mid-season.

TARTARIAN. Large purplish ish black; flesh mild, sweet, very good quality. Late June and early July.

WINDSOR. Fine large livercolored cherry. Flesh firm and good. One of the best sweet cherries.

GOV. WoOD. Large, round, heart-shaped, yellow, mottled with red, flesh sweet, juicy and delicious. Tree healthy, vigorous and a grealthy, vigorous

\section{SOUR VARIETIES}

DYEHOUSE. Very early medium size, bright red, juicy. with slightly tart flavor. with slightly tart for Excellent for canning. June.
FARLY RICHMOND. Very productive and old variety fruit dark red, medium size, tender and juicy. One of the most valuable of the acid cherries and is unsurpassed for cooking purposes. Tree slender grower, productive. June. 
MAY DUKE. Large, dark red, juicy, rich. Late June.

MONTMORENCY. Ripens about ten days after the Early Richmond. Large round handsome red; flesh fine flavored, sub-acid, rich. Recommended for kitchen and nearby market. Tree a good grower, hardy, productive. Late June.

ENG. MoreLLo. Large dark red, tender and juicy; acid, rich. A late sort.

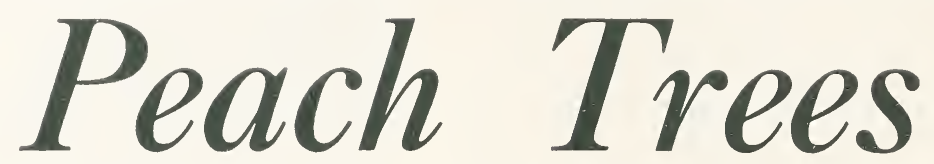

DEACH TREES grown in northern Ohio are considered by Peach orchardists as the very best. The soil and climate conditions are ideal for the growing of the trees. We grow hundreds of thousands of them every year, and many of the best orchards in the largest fruit growing districts of the northern states are from our trees. Peach trees are one of our specialties.

Peach trees need warm, well drained soil,, and should be planted 16 to 18 feet apart, and thoroughly cultivated.

Fruit is borne on the wood grown the previous season, hence it is necessary to prune the trees yearly, removing dead branches and letting in light and air. Keep the trees in good shape and you will have splendid returns.

BANNER, Large deep yellow with crimson cheek: flesh yellow and of fine quality, rich and firm. Good shipper and keeper. Tree hardy, vigorous and very productive. Last of September and first of October.

BEER SMOCI. Large, yellow, fesh red at stone, good quality and very productive. The best late market variety. Last of September and first part of October

BELLE OF GEORGLA. Very large; skin is white with red cheek; flesh white, firm, good flavor. August.

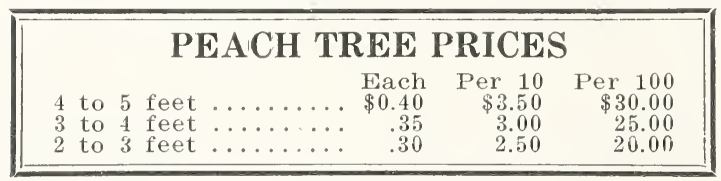

CARMEN. Large, pale yellow with deep blush. Flesh tender, white, juicy, fine flavor. Hardy First of August.

CHAIR's. Very large, deep yellow, with red cheek. Flesh firm, yellow, rich, good quality. Ripens five days earlier than the Smock.

CHAMPION. Very large, white with red cheek; flesh sweet, rich and juicy. One of the very best early peaches. August.

CRAWFORI'S RATLY Very large yellow peach; good quality and very productive. Late August.

CRAWFORD'S LA'TE. Similar to Crawford's Early but a month later in ripening. Late September.

\begin{tabular}{|l}
\hline ELBERTA \\
The leading market var- \\
iety. Fruit large, hand- \\
some, bright yellow ov- \\
erspread with crimson; \\
flesh yellow, firm, juicy, \\
good quality. Late Au- \\
gust and early Septem- \\
ber.
\end{tabular}

FIRLY ELBCRTA. Ripens about a week earlier than the Elberta; otherwise the same, or a trifle better quality.

ENGLE, A Mammoth. fine late market sort. Resemble the Crawford's. Late but is mole productive. Sept.

FITZGERALD. Large, bright yellow suffused with red; flesh yellow, best quality. Very hardy, heavy cropper. Late August.

GREENSBORO. The largest and the most beautifully colored of the early varities. Flesh white, juicy and good. July.

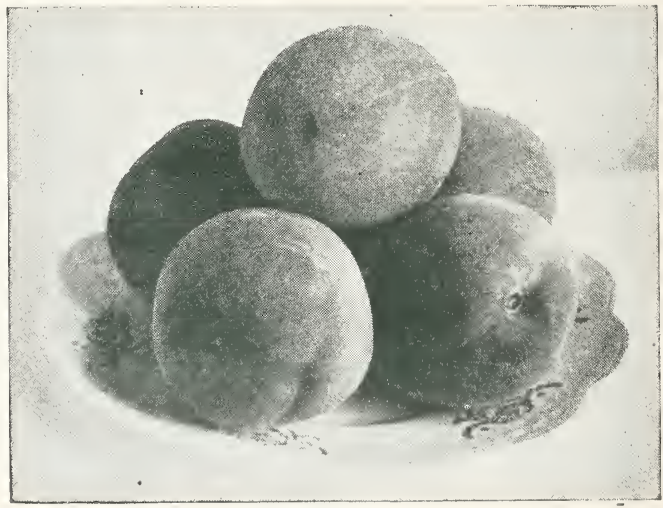

ELBEIR'TA

HALE. A large deep golden yellow peach, overlaid with bright carmine. Smooth, flesh firm fine grained and a perfect free stone. Last of August.

HEA'II CLING. Large creamy white with faint blush, fine quality and a good keeper. Valuable for preserving and canning. October.

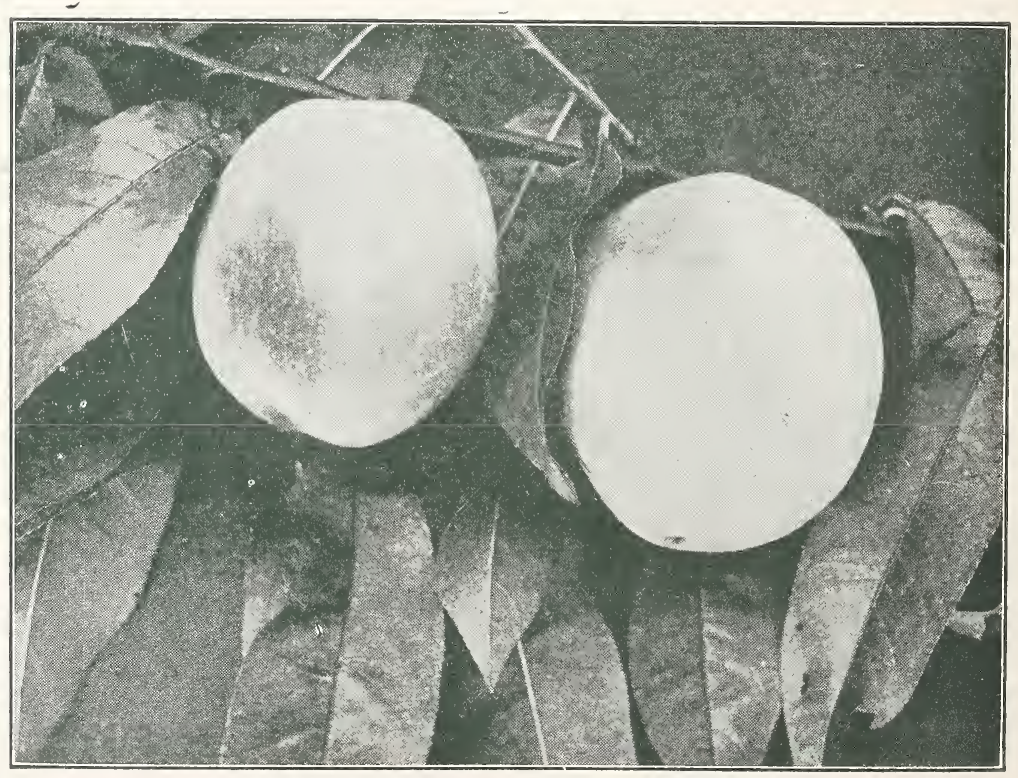

LEMON FREF 
For PHACH PRICES See Page Six
IiALAMingon cheek, fine flavor and small y it. Tree strong. hardy and regular bearer. September.

LFMON FREE. Very large lemon-shaped, pale vellow, excellent quality, very productive. One of the most valuable sorts. Very good for canning. Late September.

NIAGARA. A very large yellow peach of good quality and productiveness. Ripens just after the Elberta.

PROLIFIC. Large, yellow peach of good quality Hardy and productive. September.

\section{ROCHESTER}

Early mid-season. Color lemon-yellow changing to orange-yellow, blushed with deep, dark red. Skin thick and tough. Flesh deep, dark red. Skin thick and tough. Flesh juicy and tender. Sweet, highly flavored. juicy and tender.
Very fine quality.

\section{Quince Bushes}

The quince is always in demand, although its commercial value has changed but little for many years. Quinces are largely used in cooking, canning and preserving, as they have a delicious flavor. It is a reliable cropper and requires but little care. Yet the increased size of the fruit and the quality repay well for all the extra work given them. The trees thrive in almost any soil, but prefer a heavy moist, clay loam.

\section{QUINCE PRICES}

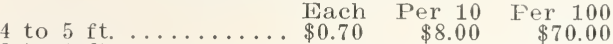

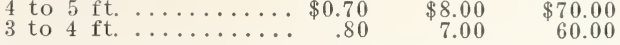
ORANGE. Large, round, bright golden yellow and very productive. The best market quince. October.

CHAMPION. Large, oblong, bright yellow, russet around the stem. 'Tree early and annual' bearer. Later than the Orange.

\section{Pear Trees}

T HE melting, juicy texture, the delicious flavor and delicate aroma of the Pear have made it popular. Our range of varieties is so wide that they may be had in good eating condition from August until early spring.

Pears, like plums, do best on a loam or clay soil, and should be planted from 15 to 20 feet apart. They begin to bear from 3 to 5 years after planting. For permanent orchards the standard trees are the best, but for small lots and home gardens the dwarf trees are much used. The dwarf trees the dwarf trees are much used. The dwarf trees are those grown or propagated on quince roots, ties are very good grown in this manner.

Pears begin bearing in a few years after pianting; seldom miss bearing at least a partial crop. for which there is always a ready sale, besides, they are one of the most healthful of our fruits.

\section{SUMIMER VARIETIES}

HAR'TLE'T'. Large, coloring when fully ripe to waxy yellow with a red blish, juicy, melting, highly flavored. Bears early and abundantly. The leading market variety. Good either as a dwarf or standard. August and September.

CLAPP'S FAVORI'TE. Large yellow flushed with red next to the sun; juicy and delightful. Earlier than the Bartlett. Tree vigorous, hardy and productive. August.

MARY. One of the best early pears. Red cheeks. Best quality.

TYSON. Medium size; yellow with russet shadings; melting, sweet and rich. August.

WILDER. Medium size; pale yellow with shadings of russet-1ed; melting and delightful, abundant bearer. Early August.

\section{AUTUMN VARIETIES}

BUERRE D'ANJOU. A large greenish pear shaded with russet-crimson; highly flavored and very productive. One of the best fall pears. October. and November.
SALWAY. Large, yellow with crimson cheek, one of the best late peaches. October.

SALHER'TA. A new variety. About a week later than the Elberta. Very hardy and productive.

STEARNS. Similar to the Elberta but of better quality, and hardier. A comparatively new variety, but is proving to be one of the best. Septem-

ELLOW S'. JOHN. Large, yellow with red cheek; fine flavor, very productive. Early August.

\section{WILMA} Elberta, not quite so elongated; better color and ripens about ten days later.

\section{Apricot Trees}

A most delicious fruit of the plum species. Is of a distinct flavor and one of our best and profitable market fruits. The tree bears young and most profusely. Ripening as it does cherries and peaches, the apricot is most welcome fruit. In very sunny localities it is apt to bloom too early in the spring and be caught by the frost. The tree is slender in form, has beautiful dark-green foliage, pretty pink blossoms, and gives very satisfactory results as an ornamental tree in any garden or house lot. To avoid being caught by late spring frosts, spread long strawy manure about one foot thick around the tree in winter.

\section{APRICOT PRICES}

$$
\begin{aligned}
& 4 \text { to } 5 \mathrm{ft} \text {. } \\
& \begin{array}{rr}
\text { Each } & \text { Per } 10 \\
\$ 0.90 & \$ 7.00
\end{array} \\
& \begin{array}{r}
\$ .00 \\
\hline
\end{array}
\end{aligned}
$$

MOORPARK. Large, orange with red cheek. August.

RoYAL. Large, yellow with red cheek. Late July.
Splendid new variety. Fruit as large as

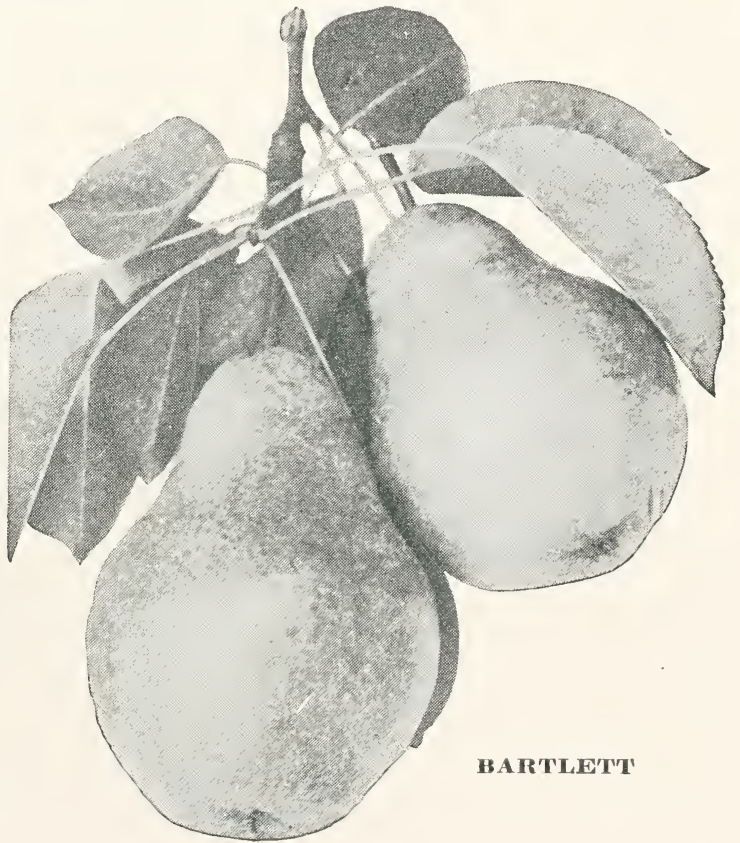




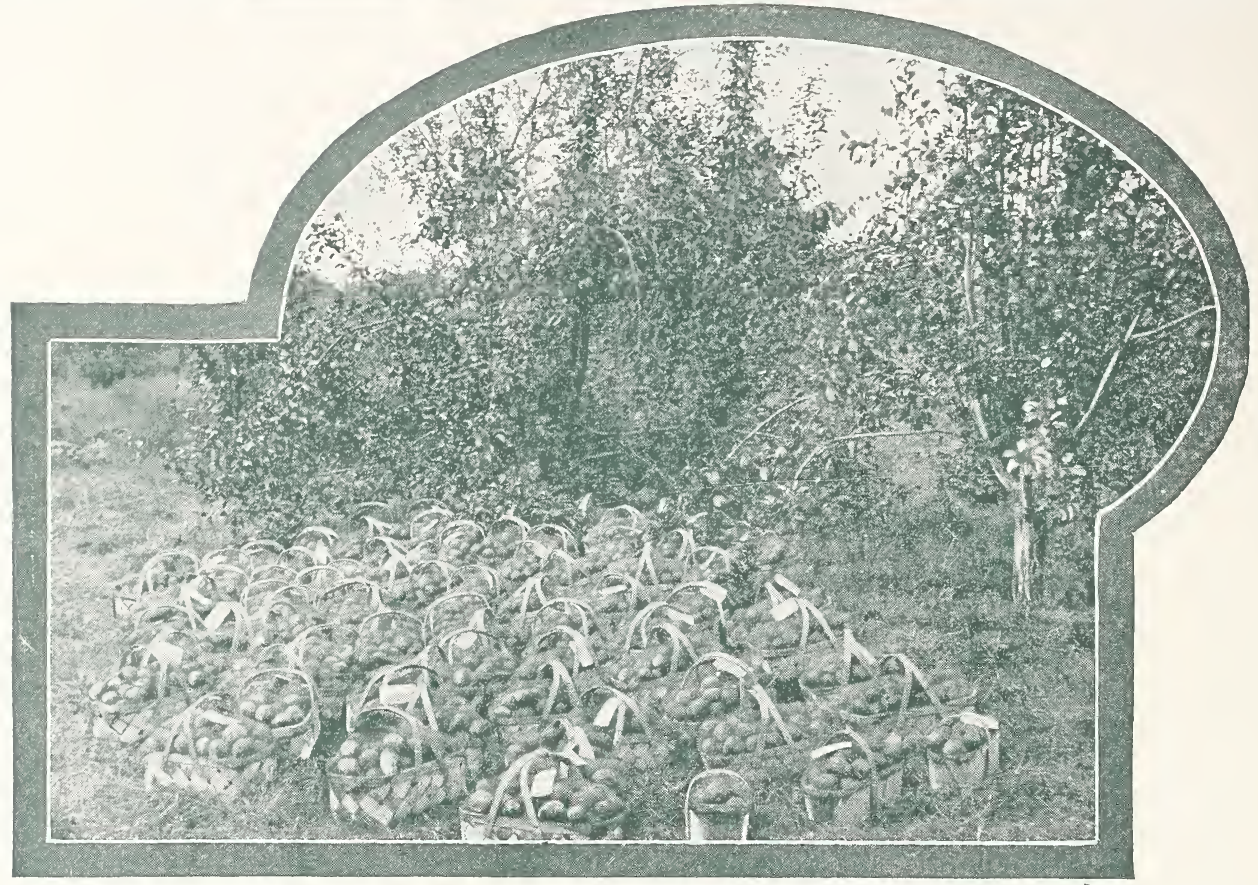

AUTUMN VARIETIES-Continued.

DUCHESS "ANGOULAME. Very large, greenish yellow spotted with russet; flesh white, juicy and rich. We recommended it as one of the best for market and home use. Especially good as a dwarf. October and November.

FLEMISH BEAUTY. Large, handsome luscious flavor. Tree vigorous and hardy, bears early and abundantiy. September and October.

\section{PEAR TREE PRICES}

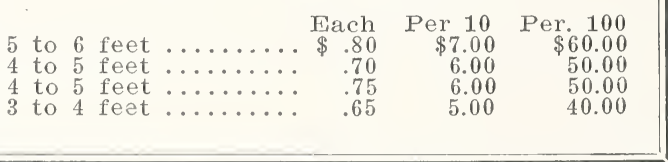

\section{Plum Trees}

W ITH only reasonably good care and culture, plum trees can be kept in healthy condition, and will produce fine crops of fruits. The market for plums is never overstocked, and they always bring good profitable returns. Plums do best on loam or clay soil, and should be planted from 15 to 20 feet apart. They will begin to bear from 3 to 5 years after planting.

\section{EUROPEAN VARIETIES}

ArCHIUKE. Reddish-purple changing to a dark blue; flesh golden yellow, juicy; good flavor Early October.

BRAISHAW. Very large, purplish-red changing to dark redrish purple; flesh dull yellow, juicy, sweet and good. Middle of August.

GERMAN I'RUIic. Large, long-oval, purplish black; flesh yellowish green, sweetish, mild and pleasant flavor. September.

\section{PLUM TREE PRICES}

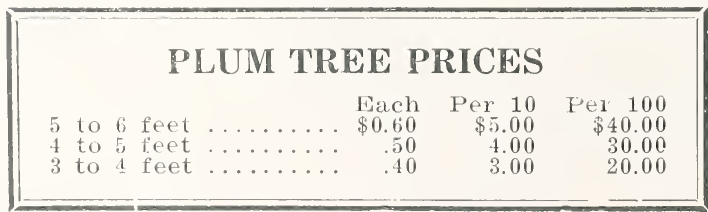

HOWELL. Fine size, bright color, excellent qualty; tree vigorous and bears early. September and October.

ISEIFFER. Large, fine appearance, good shippe

SECIFL. Beautiful and delicious; one of the richest and highest flavored pears known. Small. September and October.

SHELDor. A large, round russet and red pear of fine quality, excellent flavor, sweet and rich. October. good in quality, but larger in size and a bette

\section{WINTER VARIETIES}

AWRENCE. Medium to large size; golden yellow with melting aromatic flesh. The best winter wree hardy and productive. November and pecember. and keeper; trees bear early and abundantly.

GRAND DUKE. A valuable late plum, reddisl purple or purplish black; flesh is golden yellow, juicy, nrm, sweet, mild, and good. Late Sept.

GUII. Dark purplish black; flesh golden yellow, firm and sweet. Vigorous, hardy and productive. Early September.

\section{ITALIAN PRUNE (Fellenburg)}

One of the leading plums of western New York. Sometimes linown as York State Prune Is purplish black, flesh golden yellow, very good quality. Productive. Late August.

MONARCH. Jarge, dark purplish red; flesh yellow, juicy and tender. October. 


\section{LOMBARD}

Medium to large, purplish red; flesh yellowish, juicy, firm and sweet. Vigorous and productive. Late August.

REINE CLAUDE. (Bavay's Green Gage.) Large roundish oval, green, marked with red in sun; flesh yellow, juicy, excellent flavor Late September.

SHIPPER'S PRIDE. Large, purplish black; flesh greenish yellow, firm and sweet. A good keeper and shipper. September.

SHROPSHIRE DAMSON. The largest of the Damsons. Purplish black, flesh golden yellow. Very productive. October.

YFLLOW EGG. Large, golden yellow; juicy milc and good. Late August.

\section{JAPANESE VARIETIES}

ABUNDANCE. Medium size, amber with markings of red; juicy and stveet. Productive. August.

BURBANK. Large, deep cherry red; sweet and firm. Tree vigorous and productive. August.

RED JUNE. Large, deep red, slightly sub-acid. Early August.

WrCKsoN. Largest of the Japan Plums. A bright cherry red; flesh thick, sweet and tender. September.

\section{Grape Vines}

THERE should be Grape Vines in every home garden. For commercial purposes grapes are a very profitable venture. With but little care they will bear fruit, but good culture, pruning and spraying are well repaid by the best quality of fruit.

One of the most satisfactory crops that can be grown, because it can be depended upon practically every year.

Grape vines will grow almost everywhere, but to produce the finest specimens they should be carefully cultivated and pruned. carefully cultivated and pruned. A south or southwestern exposure
will give best results. The soil should be dry, if not, should be artificially drained before planting.

A top dressing of well-1otted manure should be applied every year, alternated every few years with a dressing of slaked lime.

Grapes can be easily trained over fences, buildings, arbors, pergolas, etc., and in this way al' ornamental as well as useful. The enemies of the grape vine and fruit are few and can be easily liept ill check.

\section{WHITE VARIETIES}

DIAMOND. A very desirable variety. Earlier than Niagara. Green with a tinge of yellow.

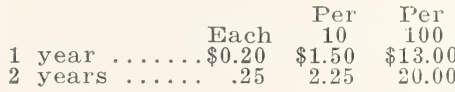

POCKLINGTON. Clusters and berries large, fairly hardy, productive; yellowish green with a tinge of amber. A little later than the Concord.

$\begin{array}{rcc}\text { Each } & \text { Per } & \text { Per } \\ 10 & 100\end{array}$

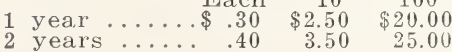

NIAGARA. The best of the white grapes. Clusters large and handsome. Light green chang. ing to pale yellowish green: ing to pale yellowish green; with the Concord.

1 year Each Per Per $\begin{array}{rrrr}1 & \text { year } \ldots \ldots \ldots \$ 0.25 & \$ 1.50 & \$ 10.00 \\ \text { years } \ldots \ldots & .25 & 2.00 & 15.00\end{array}$

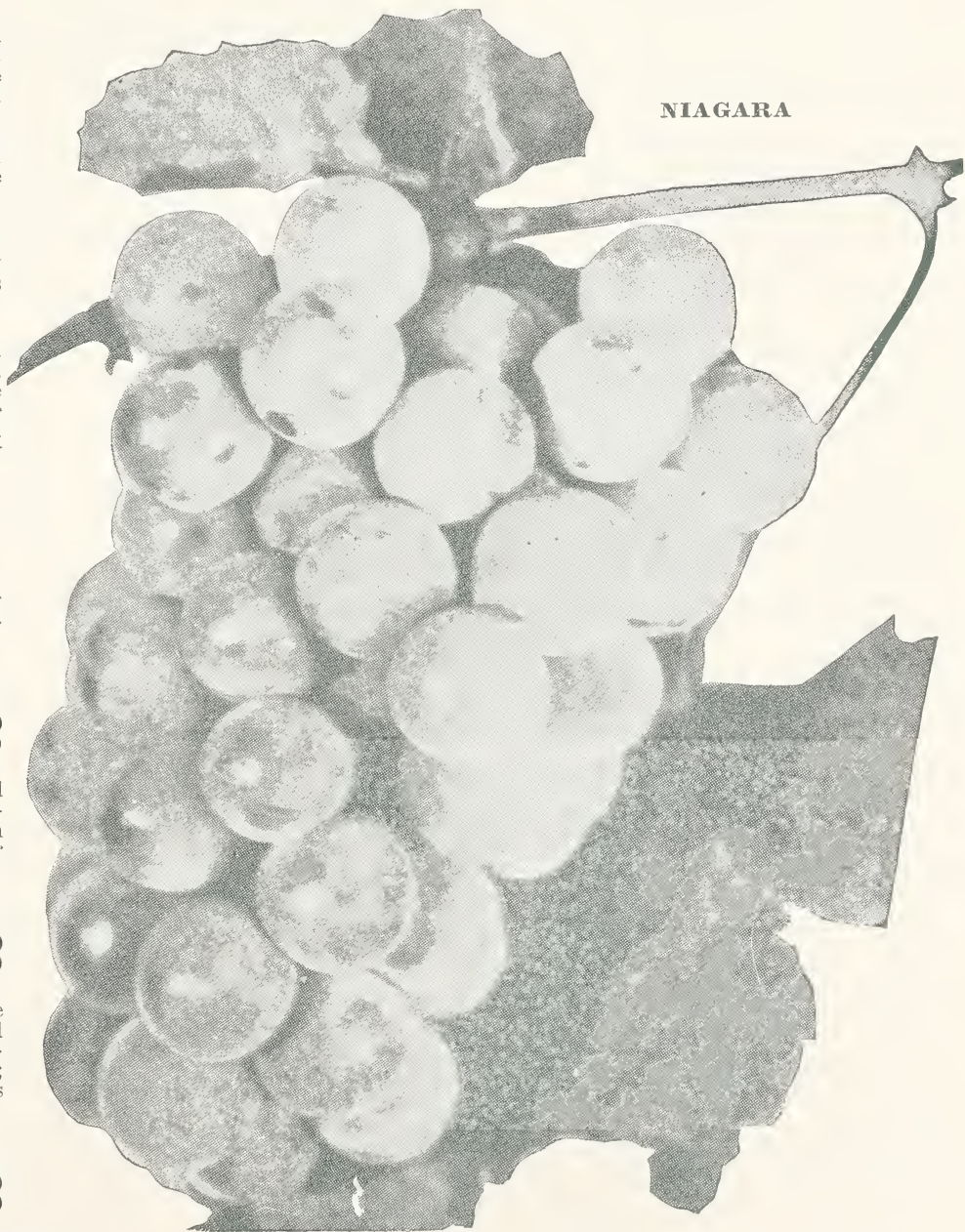

\section{BLACK VARIETIES}

CAMPBELL'S EARLY. One of the newest varieties Large, handsome, productive, dark purplish black, rather dull. One of the best early sorts.
$\frac{1}{2}$ year $\ldots \ldots \ldots . \$ \$ 0.22$
Per 10 Per 100

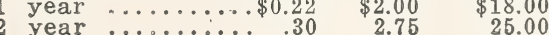

CONCORD. The leading variety for the market Large, handsome, clusters of big berries of good quality. One of the best known.

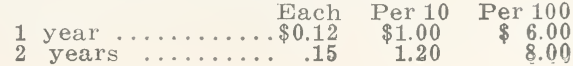


IVES. Very hardy and productive. Very desirable for grape juice or wine. Jet black with blue bloom.

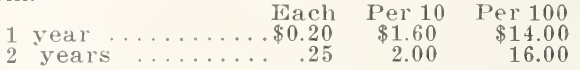

UOORE'S EARLY. Clusters of medium size; berries large, round, dark purplish black. One of the best early grapes.

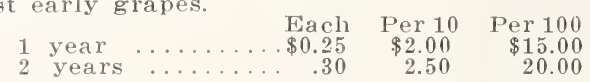

WORDEN. Seedling of the Concord, but larger in bunch and berry and of superior flavor, about tcn days earlier. Dark purplish black to black.

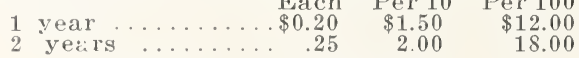

\section{RED VARIETIES}

IfAWA. A little later than the Concord. A good keeper. Dark purplish red.

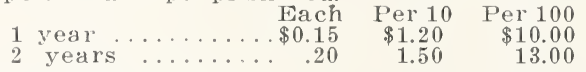

HHIGH'TON. Bunches large, well formed; flavor and duality good; ripening with the Delaware. Light and dark red.

$$
\begin{array}{rrrrr}
1 & \text { year } \ldots \ldots \ldots \ldots \ldots & \text { Each } & \text { Per } 10 & \text { Per } 100 \\
2 \text { years } \ldots \ldots .25 & \$ 2.00 & \$ 18.00 \\
& \ldots \ldots & .30 & 2.75 & 25.00
\end{array}
$$

CACO. A new variety. It is a cross between the Catawba and Concord. Fruit very large, rich wine red over amber. Exceptionally rich sugary flavor.

$$
1 \text { year }
$$

$$
\begin{array}{lr}
\text { Each } & \text { Per } 10 \\
\$ 0.70 & \$ 6.00
\end{array}
$$

CATAWBA. One of the standard table wine grapes; good sized berries and good clusters. Late. Re uuires long season. A good keeper. Dull red.

$$
\begin{aligned}
& 1 \text { year .......\$\$0.16 Per } 10 \text { Per } 100
\end{aligned}
$$

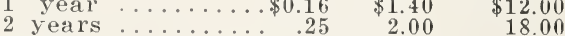

DELAWARE. A choice native grape; bunches and berries are small but compact; of the best qual. ity; light red. Very hardy.

$$
\begin{aligned}
& 1 \text { year. Each Per } 10 \text { Per } 100 \\
& 2 \text { years } \ldots \ldots \ldots \ldots .25 \quad \$ 2.00 \quad \$ 18.00
\end{aligned}
$$

SALEM. A little earlier than the Concord; it keeps and ships well; large fruit, round, very dark red with blue bloom. Very good.

$$
\begin{aligned}
& 1 \text { Each Per } 10 \text { Per } 100 \\
& 2 \text { years } \ldots \ldots \ldots \$ 0.20 \quad \$ 1.50 \quad \$ 12.00
\end{aligned}
$$

WYOMING. A week or ten days earlier than the Concord. Dark, dull red with lilac bloom.

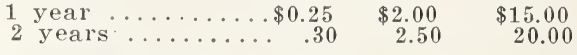

\section{NUT TREES}

$\mathrm{O}$ $\mathrm{N}$ the market, nuts are always in demand and command good prices. There is hardly another branch of tree cultivation from which there is assured such substantial profits. Not only are you each year reaping a large harvest of nuts' but at the same time the trees themselves are growing into many dollars in the form of lumber.

MERICAN SWEE' CHES'TNU'. The native American Sweet Chestnut. It is useful both for ornamental purposes and for timber. The nuts are sweet and very desirable to grow for commercial purroses. No farm should be without its chestint girove.

$$
\begin{array}{rrrrrr}
6 & \text { Each } & \text { Per } 10 & \text { Per } 100 \\
5 & \text { to } 6 \text { feet } \ldots \ldots & \$ 1.20 & \$ 10.00 & \$ 90.00 \\
& & &
\end{array}
$$

MERUIMAN CHES'INU'T. This is a cross between the Paragon Chestnut and the American Sweet. It is perfectly hardy and vigorous and enor- mously productive. Nuts of immense size, measure three inches in circumference and sonietimes more. It was originated within a mile of our nulsery, and we think it is one of the most desirable trees for planting that was ever introduced.

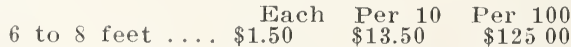

ENGLISH WALNU'S. Although not always hardy in our northern climate, they are desirable trees to grow.

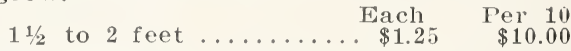

IB IACR WALNU'. The large oily nuts are borne in heavy crops. The tree grows quite fast and it. dark rich wood is exceedingly valuable.

$$
2 \text { to } 3 \text { feet .......... } \$ 0.85 \quad \text { Per } 10
$$

BU'T'IER U'T'. Native tree, producing a large nut Has a sweet, oily, nutritious kernel.
3 to 4 feet
Each
Per 10
$\$ 0.75$

\section{Gooseberries}

Gooseberries should be planted in good, rich soil and well manured once a year. Pick regularly, thoroughly cutting out all deadwood and surplus branches. Plant in rows 4 feet to 6 feet apart in rows. It is well to mulch heavily in the fall. Plants are hardy, rugged and easily grown.

CHAC'IAUQUA. Large white gooseberries of excellent quality. Very fine. Vigorous upright bushes, hardy and productive.

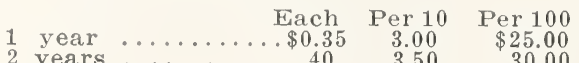

DOWNING. A large, handsome, light green berry of: excellent quality. Very vigorous and productive. Very profitable commercial variety.

$$
\begin{array}{lllrr}
1 & \text { year } \ldots \ldots \ldots \ldots \ldots & \text { Each } & \text { Per } 10 & \text { Per } 100 \\
2 & \text { years } \ldots \ldots .30 & \$ 2.50 & \$ 20.00 \\
2 . \ldots . & .35 & 3.00 & 25.00
\end{array}
$$

HOUGHTON. Fruit medium size, pale red, good.

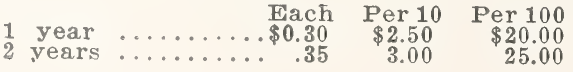

JOSSFLYN. Large, hardy, bright red.

Each Per 10 Per 100

1 year $\quad \begin{array}{lll}\text { Each } & \text { Per } 10 & \text { Per } 100 \\ \$ 0.40 & \$ 3.50 & \$ 30.00\end{array}$

\section{Mulberries}

The Mulberries are both fruit and ornamental trees. While few people care for them alone they add a wonderful flavor when cooked with other fruit. As their fruit ripens over a long period they are doubly valuable.

RUSSIAN. Very hardy. Much used for wind break. Fruit of very little value.

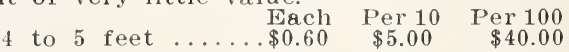

DOWNING. Is very prolific. Fruit large, black, subacid.

$$
\begin{array}{r}
5 \text { to } 6 \text { feet } \ldots \ldots \ldots \\
4 \text { to } 5 \text { feet } \ldots \ldots \\
1.00
\end{array}
$$

NEW AMERICAN. Vigorous. Very prolific. Fruit very large, black, sweet, rich and delicious, ripening from June to September.

$$
\begin{array}{rrr}
5 \text { to } 6 \text { feet } \ldots \ldots \ldots & 1.00 \\
4 \text { to } 5 \text { feet } \ldots \ldots \ldots & .90
\end{array}
$$




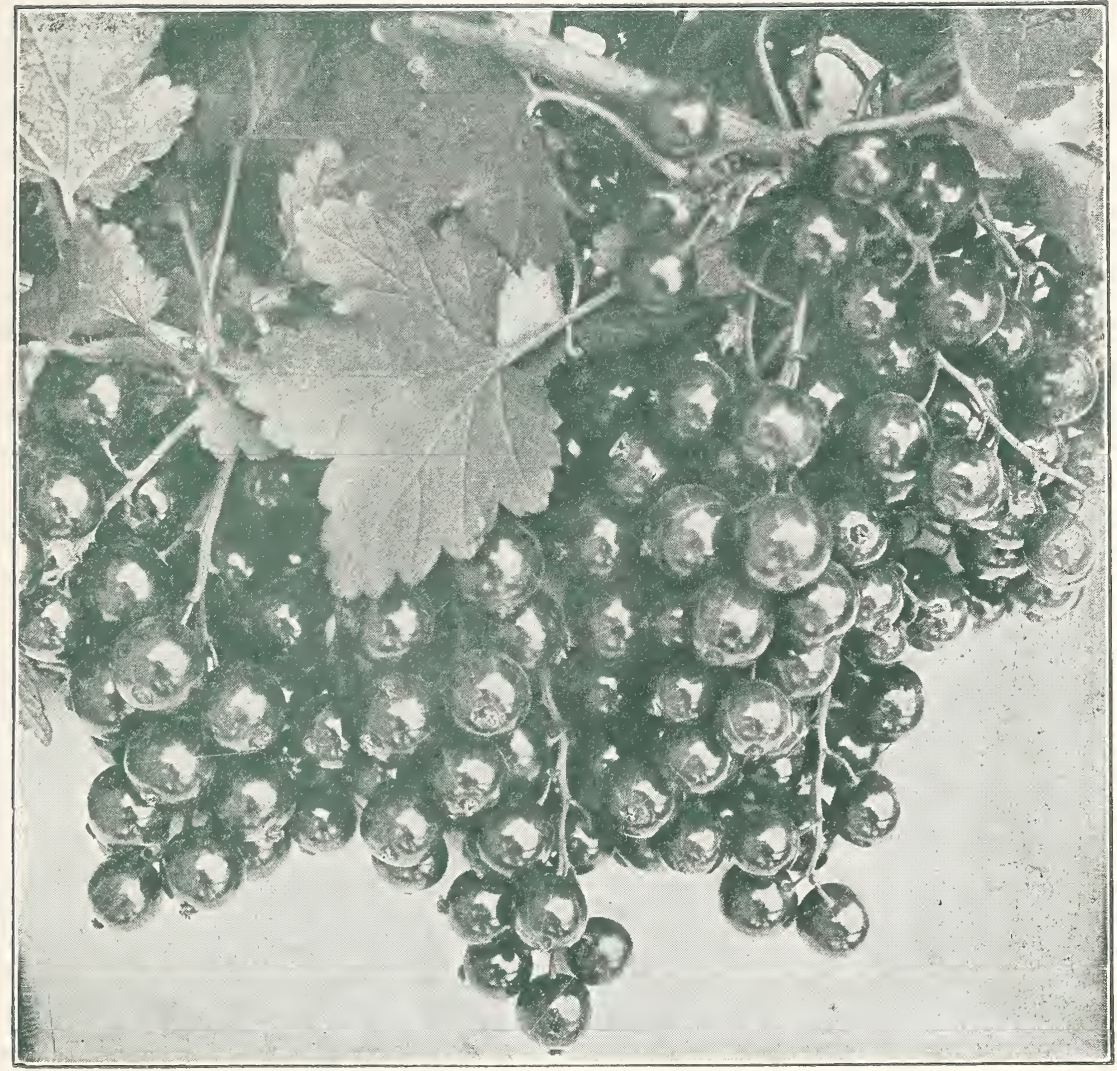

\section{Currants}

$\mathrm{T}$

HE currant is one of the most reliable of small fruits. They mature just before raspberries and can be used either raw or cooked. Being hardy, they do not winter kill, are easy of cultivation and require little care. They can be grown in any good garden soil, about four feet apart. The market is never over supplied. Prune out dead wood, and mulch heavily. If currant worms appear, dust with hellebore.

\section{RED VARIETIES}

FAY'S IROLIFIC. Extra large, long stems and kerries. Tery productive.

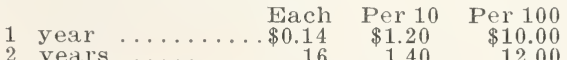

PERFEC'ION. Beautiful bright red, larger than the Fay's. Very productive.

$$
\begin{aligned}
& 1 \text { year Each Per } 10 \text { Per } 100
\end{aligned}
$$

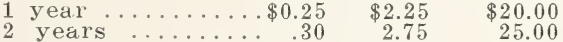

LONHON MARKE'T. Hardy, good color and size. Heavy cropper.

$$
\begin{array}{lllr}
\text { year } \ldots \ldots \ldots \ldots .15 & \text { Pach } 10 & \text { Per } 100 \\
\$ 0.15 & \$ 1.20 & \$ 10.00
\end{array}
$$

WILDER. The very best, bunch and berry very large, enormously productive, a strong grower. Will hang on the bushes in good condition for some time after ripening.

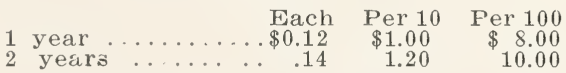

\section{WHITE VARIETIES}

WHITE: GRAPE CURRAN'TS. Large, handsome clusters of yellowish white berries. Best quality.

$$
\begin{aligned}
& \text { Each Per } 10 \text { Per } 100 \\
& 1 \text { year .........\$0.16 \$1.40 \$12.00 }
\end{aligned}
$$

\section{Blackberries}

Blackberries are one of the most profitable of our small fruit cropis, and should be grown on every farm and fruit plantation.

The blackberry thrives well in almost any soil, but to reach perfection, demands a strong loam. tending towards clay, rather than sand. In many paits of the country winter protection is a necessity and often ados greatly to the yield where not considered really essential. The pruning of the blackberry is not a difficult task, yet success depends upon the proper method. The old canes should be removed early; it is preferable in the summer after they have borne their crop of fruit. Cultivation should be frequent ${ }^{-}$but shallow, as deep cultivation disturbs the roots and induces them to sucker. Pinch back the canes when three or four feet high. It is not best to allow more than three canes to a hill. Blackberries should be planted about four feet apart in rows seven feet apart.

BLOWER. Originated in the fruit belt of western New York and has been thoroughly tested for several years. It has proven to be perfectly several years. It has proven to be perfectly finest quality, large size jet black, and a good shipper. 
Blackberry Prices $\begin{array}{ccr}\text { Each } & \text { Per } 10 & \text { Per } 100 \\ \$ 0.75 & \$ 6.00 & \$ 50.00\end{array}$

EARLY HARVEST. One of the first to ripen, very productive, but sometimes winter kills in the north.

ILDORAD0. The vines are very hardy and vigorous, and enorinously productive. The berries are very sweet.

\section{RASPBERRIES}

$\mathrm{R}$ ASPBERRIES will do well in any soil not too wet. Keep cultivated and free from weeds; old canes should be cut as soon as done bearing, to give vigor to the new wood. Plant three feet apart in rows six feet apart.

\section{PURPLE VARIETIES}

COLUMBIAN. Very large, purplish red good flavor, enormously productive, strong grower.

\section{BLACK VARIETIES}

CUMBERLAND. The best of all the blick caps. Fruit very large, of the best quality, firm and handsome, canes healthy, hardy and vigorous.

FARMER. (Plum Farmer.) Large, black, said to be its large as the Cumberland and as productive, and about the same season.

KANSAS. Early Variety. We consider it the most dependable variety known. Berries jet black and of the best quality; calles vigorous, free from disease and hardy.

\section{RED VARIETIES}

MUNGER. Larger, hardier, and more productive and of better quality red than the Gregg. About a week later than that variety. Was first grown in western Ohio from a seed of the Shaffer.

CUTHBER'. The leading market variety. The berries are of large size and bright red in color. very productive ous and healthy.

KING. Earlier than the Cuthbert. Large, bright red; very productive

ST'. REGIS. Continuous-to-fall bearing red raspberry. The fruit ripens with the earliest and continues until October. Bright crimson, large size.

JUNE. Tested with seventy other varieties at the New York Experimental Station, this unusual new berry was the only one to bear rruit in June, and in this manner its name was gained. Besides its early bearing, there are other remarkable advantag.es. It is quite mornless! Berrieses. It is quite than Cuthert, larger than cuthbert, and are borne in great profusion over a long period.

HARBERT. Hardy, bright red, fine

\section{YELLOW VARIETIES}

GOLDEN QUEEN. Berries large, a beautiful pale amber yellow. Canes hardy of the strongest growth and productive.
MERSEREAU. A strong grower and is claimed to be the hardiest blackberry, standing uninjured 20 degrees below zero. Very productive, of good size, berlies of excellent quality. Ripens late.

SNYDEIR. Medium size. Hardy, early.

TAYLOR. Berries of fine flavor and large. Canes vigcrous, of ironclad hardiness, very prolific. Ripens late.

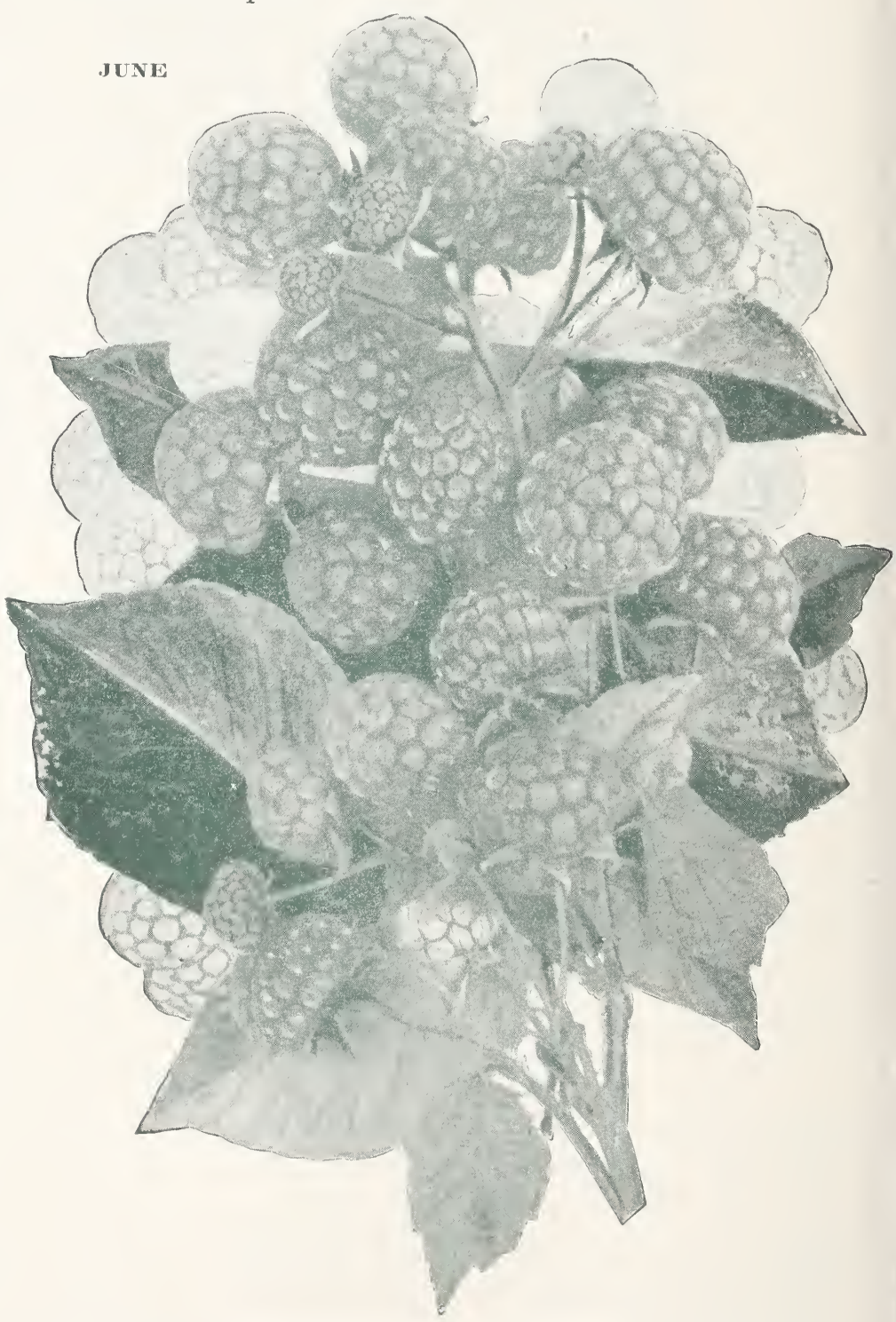

\section{RASPBERRY PRICES}

PURPLE VARIE'TIES

$60 \mathrm{c}$ per $10 ; \$ 4.00$ per 100 BLACK VARIE'TIES

$50 \mathrm{c}$ per $10 ; \$ 3.50$ per $100 ; \$ 30.00$ per 1000 RED VARIETIES

Cutbloert, King and $\mathbf{S t}$, Regis

$50 \mathrm{c}$ per $10 ; \$ 3.50$ per $100 ; \$ 30.00$ per 1000
June and Herbert

80 c per $10 ; \$ 6.00$ per $100 ; \$ 50.00$ per 1000 YILLOW VARIETIES $80 \mathrm{c}$ per $10 ; \$ 6.00$ per 100 LA'THAM

$\$ 1.00$ per $^{*} 10 ; \$ 7.50$ per $100 ; \$ 50.00$ per 1000 


\section{LATHAM RASPBERRIES}

This is a camparatively new variety but is considered one of the very best Red Raspberries grown. Ripens with Cuthbert and is enormously productive. Berries much la'rger than any other Red Raspberry, many of them one inch in diameter. Berries dark red and of fine quality, $\$ 1.00$ per $10 ; \$ 1.75$ per 100 ; $\$ 50.00$ per 1000 .

\section{Rhubarb}

Ranks among the very best of the early products of the garden. After the long, dreary winter months jt furnishes the first material for fine pies and delicious table sauce. To produce tender and quick growth, the ground must be kept very rich.

LINNA HUS. Leaf-stalks, large, tender, juicy; quite early.

QTEEN. The extra-large, tender stalks are a decided pink color, and splendid for canning.

$\$ 1.50$ per $10 ; \$ 8.00$ per 100.

\section{Strawberries}

UR Strawberry plants are taken from beds set especially to produce plants. Each variety is kept by itself. Our soil is especially adapted to growing strong and healthy plants, and we have been very successful in that line.

Strawberries will succeed in any soil that is adapted to ordinary farm or garden crops. Soil should be thoroughly prepared to a good depth, well drained and fertilized. For field culture, set in rows 3 or 3 1-2 feet apart, 15 to 18 inches in the rows; for garden, 15 inches apart each way, leaving a pathway every third row.

The varieties marked (Per) are perfect flowering or staminate; and those marked (Imp) are imperfect or pistillate.

AROMA. (Per) Plant shows no weakness of any kind. Fruit very large, roundish, conical, rarely misshapen, glossy red, of excellent quality and produces in abundance. Standard variety.

BEL'T. (Per) Very large conical, bright red, good flavor; the plant is strong, healthy and productive. One of the best berries. Season medium to late.
DUNLAP. (Senator Dunlap) (Per) The great home and market berry of the present day. Large deep red. very firm and of excellent quality. Very early and bears nearly a month.

\section{STRAWBERRY PLANT PRICES}

$\$ 1.00$ per $100 ; \$ 8.00$ per 1000 .

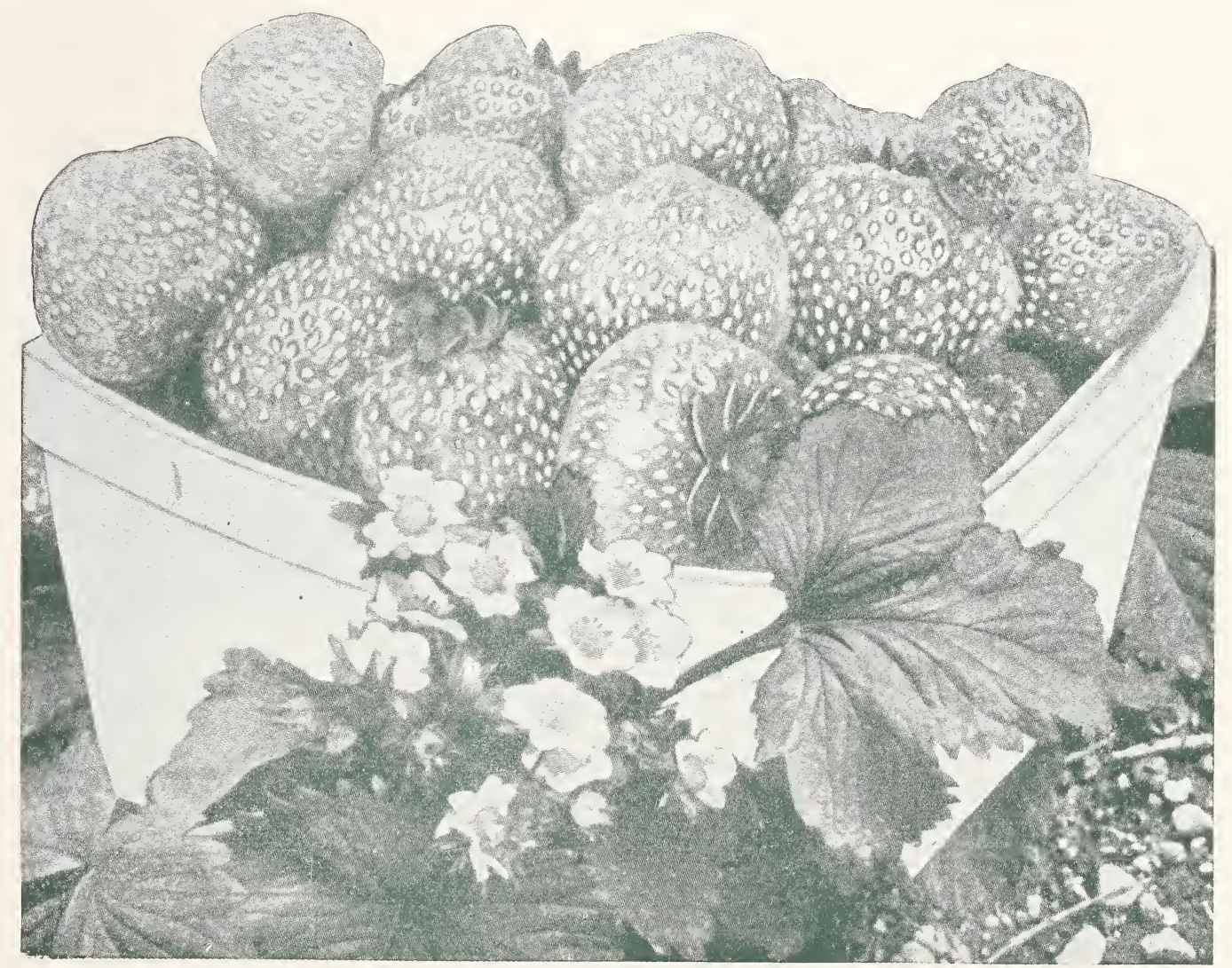


GLEN MARY. (Per) Fruit large, sweet rich, good color. Plants vigorous and productive. Is firm and a good shipper.

GIBSON. Ierries large fine flavor, a deep $r e d$

JESSIE. (Per) Very large, handsome dark red. On some dark red. On some tive.

PREMIER (Per) The finest early berry; large size, fine appearánce.

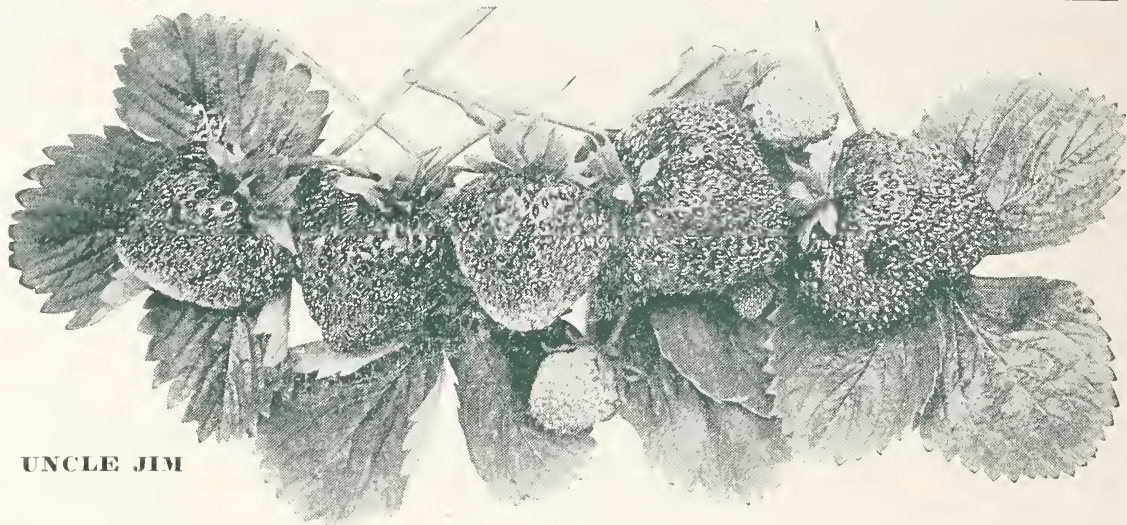

PARsons. (Fer) Very large, bright red, firm, a good shipper. A fine large plant and very productive. A very profitable berry. Midseason.

SAMPLI. (Imp) The leading market variety of today. Large size, good color, heavy cropper.

UNCIE JIM. (Per) One of the newest varieties: very large; beautiful color; excellent quality. A very large; beautiful
very valuable berry.

\section{EVERBEARING VARIETIES}

Everbearing varieties are receiving a great deal of attention and berries being picked all through the fore part of October. The Everbearing berries should be transplanted each year in order to insure their fruiting, but the extra time and attention is well repaid by the luscious results.

Everbearing Strawberries have proved one of the greatest horticultural finds of the century. 500 plants will not only supply the home with delicious strawberries from early spring until freezing weather in the fall, but give a surplus for canning or market. After the second spring

crop it has been found more profitable to plow the bed up and set a new one.

SUPERR. Very large, dark red and glossy, fine quality. It begins to bear in June with immense crops and continues until late in the fall. It is one of the heaviest bearers of berries in June as well as a remarkable fall bearer. Will produc a fair crop of fruit first summei.

PROGRLASIVE. (Per) One of the finest berries of the market today. Everbearing; fine color; shapely; delicious. Will bear fruit until late October. A very desirable variety for the home garden from the fact that it bears great quantities of fruit.

\section{EVERBEARING VARIETIES}

$\$ 1.50$ per $100 ; \$ 10.00$ per 1000

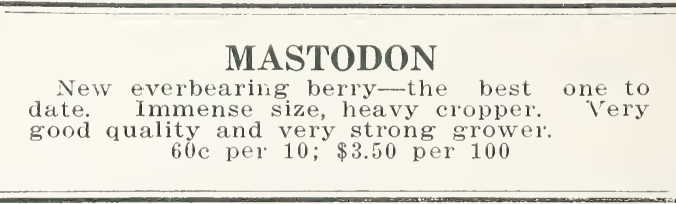

\section{Dewberries}

The Dewberry is a trailing or vine form of the blackberry. May be trained to run over stone piles over rough embankments or rocky hillsides, and sometimes produce a very large crop of fruit annually over land where no other crop could be grown. The fruit is very large and always at a premium with the commission men or the open market. Should be protected in winter with a coarse litter.

LUCIRE'IA DWWBERRY. One of the low growing trailing blackberries; large berries and ripens early. 30 cts. per $10 ; \$ 2.50$ per 100 .

\section{Asparagus}

Every home with a garden, in the country or city, should have a good sized bed of asparagus. Nothing is easier to plant or care for, and its being among the first fruits of the garden makes it a universal favorite. In a commercial way the supply is always inadequate and the price high. Flant in rows, setting the roots 18 inches apart. Spread in rows, setting the roots 18 inches apart. Spread low the surface of the ground, top-dressing annually with well rotted manure.

ASPARAGLS. Columbian, Conover and Palmetio.

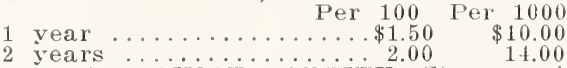

COLCMHAN MAMiorii wirie. Strong, vigor-

ous; large white shoots.

conover's colossiu. Large, tender, deep green shoots.

PALME'Tro. A very early variety, very large and regular in size. A new rust-resistant Asparazus. A new rust-resistant Asparasus.
As a standard variety for the production of fancy asparagus for the home or market, it stands ahead of all others in size, vigor, tenderness, and quality.

$$
\begin{aligned}
& \begin{array}{ll}
1 & \text { year } \\
2 & \text { years }
\end{array} \\
& \text { Per } 100 \text { Per } 1000 \\
& 15.00
\end{aligned}
$$

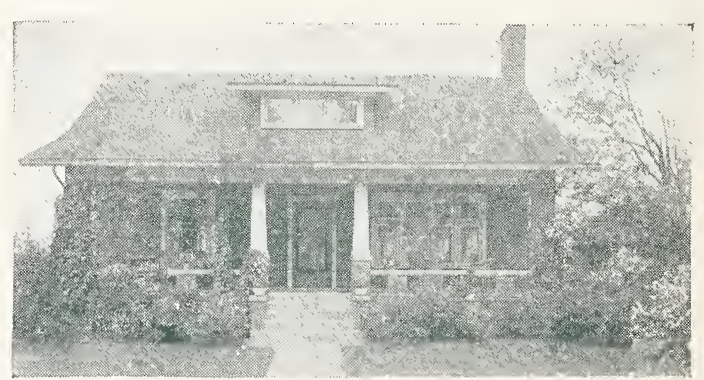

\section{Attractive Landscape Effects}

THE beautiful effects of shrubs and trees about your home are not hard to get when almost every home magazine you pick up offers suggestions.

We will send free, the little booklet, "How to Plant Your Home Grounds," by E. T. Wilson upon request. Send for it today. 

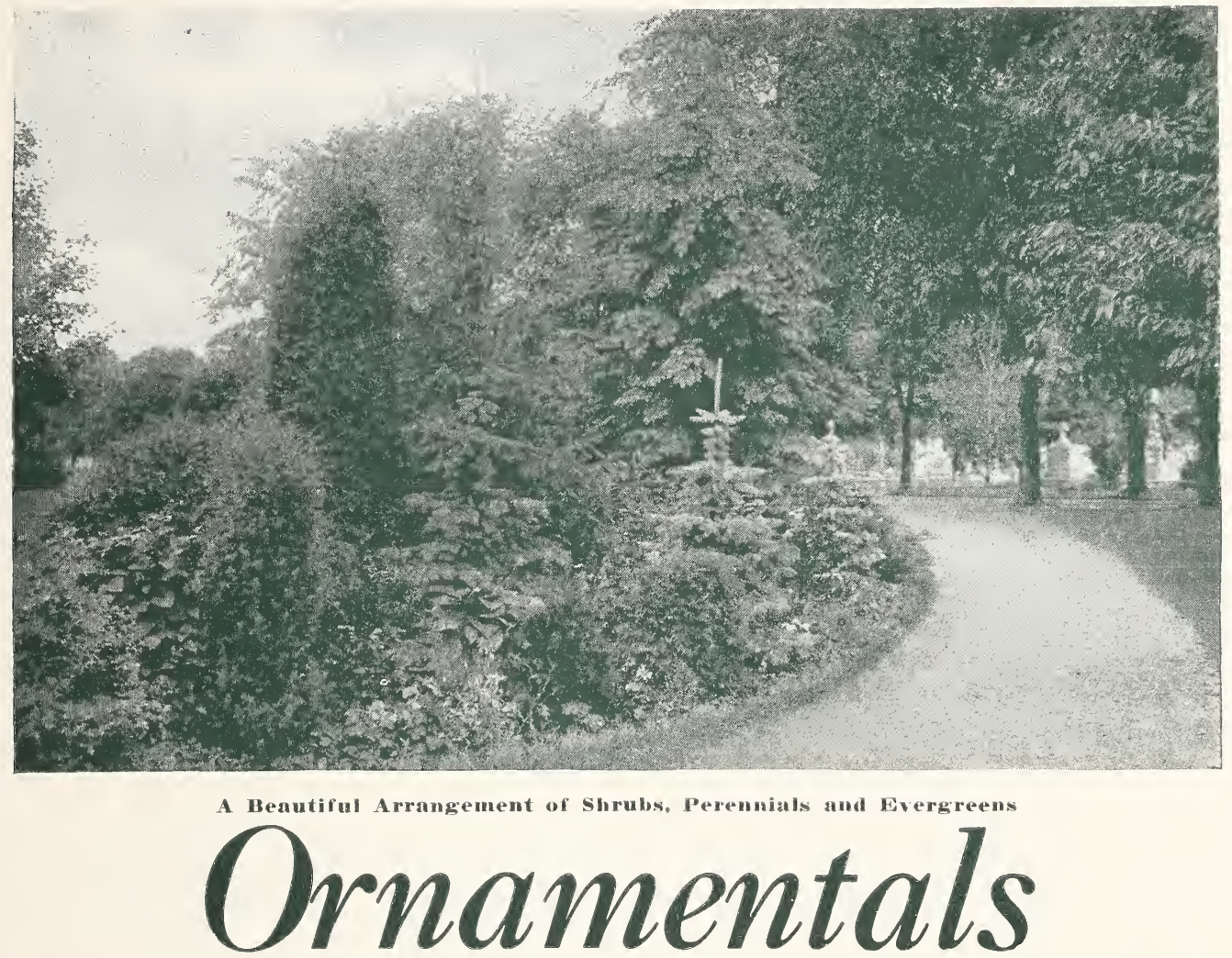

M

OST people, whether in the country or in the city, do not need any arguments to convince them that home plantings will improve the looks of their place and add to their home comforts. The only reason that we can see why they have not taken advantage of these things is the belief that it takes too much money, too much skill and care to plan the grounds and plant them in proper order. This is an entirely wrong idea; the expense is comparatively slight, $t h$ e labor of planting amounts to very little, and almost every home owner can make a reasonably good selection of trees and shrubs that ought to be around his place. Only on the very large places would the services of a landscape architect be needed.

Of course one ought to know something about the habits of trees and shrubs used, and select those that are adapted to the location, soil and to the climate; otherwise the results would not be altogether satisfactory. The foundation work can be screened with low-growing shrubs like the Barberry, Anthony Waterer Spirea, or with lowgrowing evergreens; at the curves in the drives and walks, clumps of evergreens, groups of flowering shrubs, or peonies may be used to advantage.

About the lawn, maples, evergreens and shrubs can be used to good effect and a Privet or Barberry hedge is far superior to the most elaborate fence.

The worst "barn of a place" can be changed into an attractive and desirable residence so far as outside surroundings can make it so, and the merely expensive home can be changed to a really beautiful place. Each tree and shrub has a definite use and nine times out of ten the average home owner will select and place these trees and home come appearance that he has so ardently longed for.

Through the whole list of handsome and quickgrowing trees and shrubs we have desirable specigrowing trees and shrubs we have grown on good mens to offer. They have been grown on good soil under the best conditions, and by men who
understand growing deciduous and evergreen trees.

\section{PLANTING HINTS}

In preparing the ground for the trees dig at least two feet deep and three feet wide Thoroughly mix the soil you take out, and then you can put about a foot of it back.

Start the trees 10 inches deeper than you want them to set. Sprinkle fine dirt in among the roots, and as you continue to do this, jolt the tree up and down so as to settle the dirt in anlong the fine roots. As the hole fills up keep packing the dirt. Use a heavy maul and come down on the dirt with all your weight. You cannot get it too tight about the loots. The top inch or two of dirt, however, should be loose to conserve moisture. Trees finally should set just about two inches deeper than they did in the nursery.

After planting you may water the trees liberally. We strongly recommend that you mulch immediately underneath newly planted trees. Hay, cut straw, and strawy-manure are good material to use for this. A layer six illches thick is not too deep. Such a mulch will keep the ground damp all the time and will prevent nearly all evaporation. Unless you use this mulch it will be necessary to hoe around the mulch it will be necessary th the after-treatment is determined easily. 


\section{Deciduous Trees}

THERE are several good reasons for planting of the summer sun; they provide: a cool spot where the children can play; they make the place more pleasing and they greatly increase the value of the home.

To increase the beauty of your place, plant shade trees, now, this year, and in a few seasons you will begin to realize that the small cost of the trees was one of the best investments you ever made.

AILAN'IHUS GLINIDULOSA. (Tree of Heaven.) A lofty, rapid growing tree with pinnate palm-like leaves, Free

$6-8$ ft. $\$ 1.50$ each; $\$ 12.50$ per 10 . $8-10$ ft.- $\$ 1.75$ each; $\$ 15.00$ per 10.

\section{ASH}

A MERICAN WHITE. Forest tree, tallest of the species, with straight clean trunk, smooth gray
barl and glossy leaves.

$8-10$ ft. $-\$ 1.50$ each; $\$ 12.50$ per 10

10-12 ft. $\$ 1.75$ each; $\$ 15.00$ per 10 .

EUROPEAN. Somewhat smaller than the American Ash, with short thick trunk and darker foliage. Remains green in fall.

$8-10$ ft. $\$ 1.50$ each; $\$ 12.50$ per 10 .

$10-12$ ft. $\$ 1.75$ each; $\$ 15.00$ per 10.

\section{ALIMOND}

DOUBLE FLOWERED. A beautiful little tree which bears a profusion of rose colored blossoms in early spring.

3 to 4 feet- $\$ 1.50$ each; $\$ 12.50$ per 10 .

\section{BIRCH}

EUROPEAN WHITE. A vigorous tree, snow white bark, dark green foliage; very graceful and handsome. 8 to 10 feet- $\$ 2.75$ each; $\$ 25.00$ per 10.
10 to 12 feet- $\$ 3.00$ each; $\$ 27.50$ per 10.

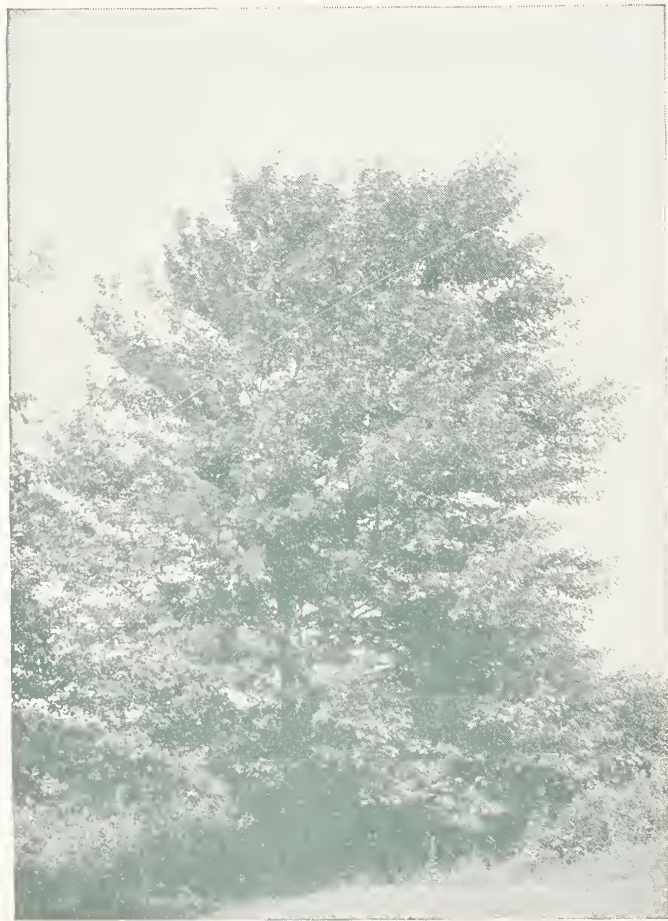

SILVER MAPLE

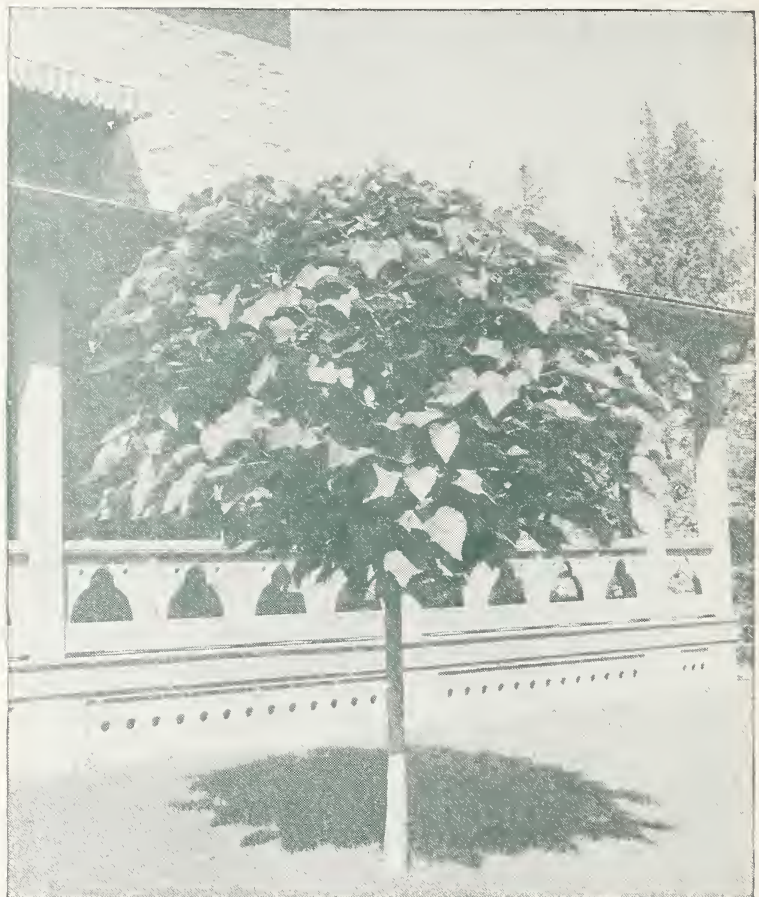

CATALPA BUNGEII

CATALPA

BUNGEII. (Umbrella Catalpa.) Grafted on a stem six to eight feet high, it makes an umbrella shaped top without pruning. Perfectly hardy; flourishes in almost all soils and climates. Leaves large, glossy heart-shaped deep green. A very large, glossy he

$$
2 \text { Year. }
$$

5 to 6 feet- $\$ 2.50$ each; $\$ 22.50$ per 10 .

6 to 8 feet- $\$ 3.00$ each; $\$ 27.50$ per 10 .

SPECIOSA. A rapid growing tree which is valuable for timber, fence posts, railroad ties, etc. Large, downy, heart-shaped leaves with racemes of Ivite flovers in June, folloved by lomg narrow beans.

8 to 10 feet- $\$ 1.25$ each; $\$ 10.00$ per 10 .

\section{CORNUS}

FLoridna. (White Flowering Dogwood.) Large white flowers in early spring, young growth bright red.

3 to 4 feet- $\$ 1.25$ each; $\$ 10.00$ per 10 .

FIORIDA IRCBRA. Handsome red flowers displayed at even an earlier age than those of the White Dogwood.

3 to 4 feet $-\$ 3.00$ each; $\$ 27.50$ per 10 .

\section{CRAB}

ATROSANGUINEA (Carmine). Makes a beautiful contrast to the other varieties by reason of its darker red flower's. The buds are deep purplish red, and the entire flower tinged purplish.

$$
\begin{aligned}
& 3-4 \text { feet } \$ 1.25 \text { each } \$ 10.00 \text { per } 10 \\
& 4-5 \text { feet } \$ 1.50 \text { each } \$ 12.50 \text { per } 10
\end{aligned}
$$

BECH'TOL' DOUBLE FLOWERING. The tree is sturdy, hardy, and free from disease, of medium size, and when in bloom present the appearance of being covered with delicate pink roses of medium size. Very fragrant.

2 to 3 feet $-\$ 1.25$ each; $\$ 10.00$ per 10

3 to 4 feet-\$\$1.50 each; $\$ 12.50$ per 10 


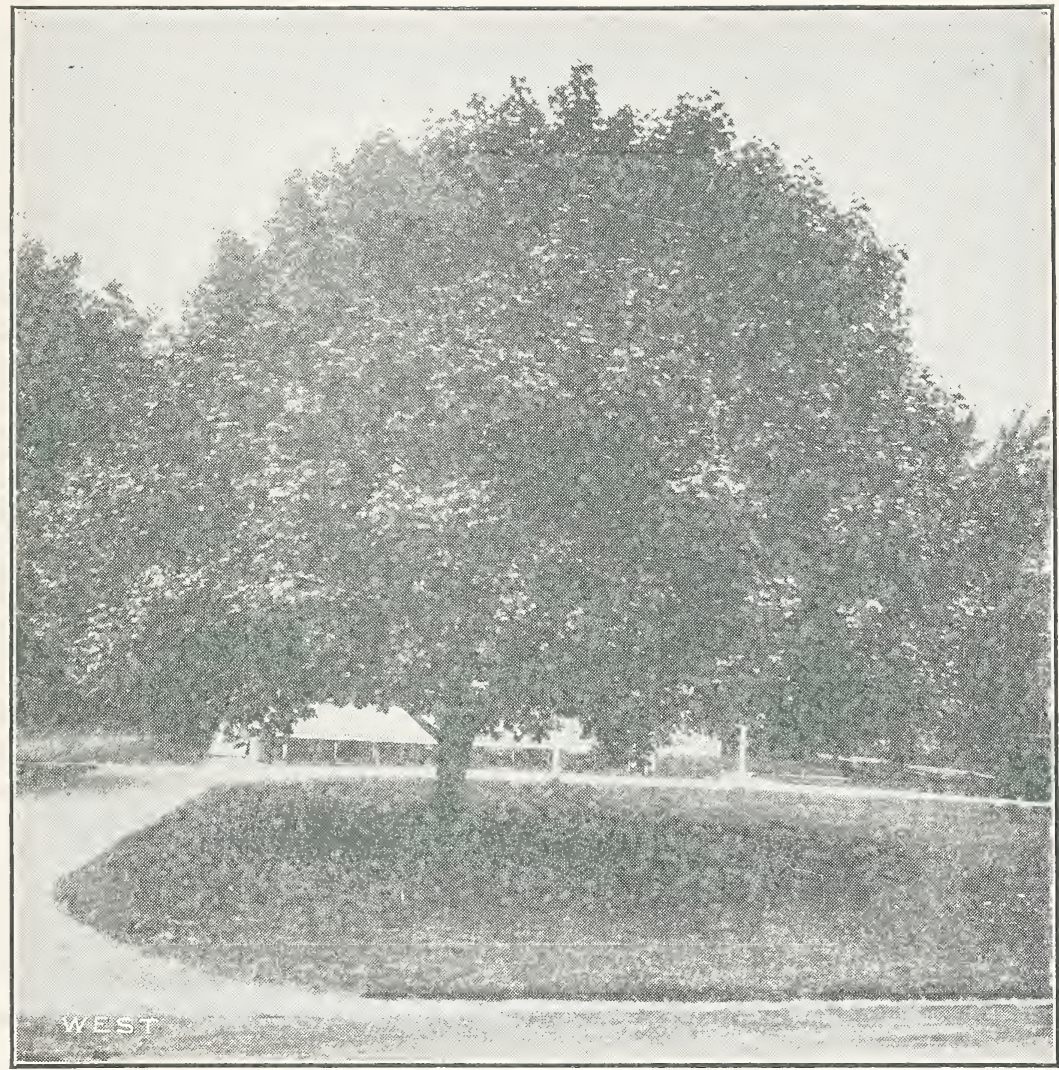

\section{CRAB Continued}

FLORIBUNDA (Japanese Flowering). A l a $\mathrm{rg}$ shrub or small tree, often thorny, witl rose-red flowers borne in great profusion' in May. 'The fruit is red and very small.
$\begin{array}{lll}3-4 & \text { feet } \$ 1.50 & \text { each } \\ 4-5 & \text { feet } \$ 1.75 \text { each }\end{array}$
$5-6$ feet $\$ 2.00$ each
$\$ 12.50$ per 10
$\$ 15.00$ per 10
$\$ 17.50$ per 10

FLORIBUNDA PURPUREA. A beautiful form of above with darker red flowers.
$3-4$ feet $\$ 1.25$ each
$\$ 10.00$ per 10
5 feet 1.50 each
$\$ 12.50$ per 10
5-6 feet $\$ 2.00$ each
$\$ 17.50$ per 10

HALLIANA I'ARKMANI. An e $\mathrm{l}$ e g a $\mathrm{n} t$ Japanese dwarf with long-stemmed, semi-double flowers of deep rose color wreathing its branches. The buds are long and handsome.

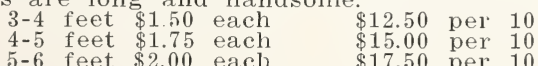

SEIBOLDI ('Toringo). A very irregular tree in habit of growth with small single white flower's. Dwarf growing variety.

3-4 feet $\$ 1.50$ each

$$
4-5 \text { feet } \$ 2.00 \text { each }
$$

SPEC'TABILIS (Chinese Flowering). A very showy variety. Double deep coral-red bloom Glows

$$
\begin{array}{ll}
3-4 \text { feet } & \$ 1.25 \text { each } \\
4-5 \text { feet } & \$ 1.75 \text { each } \\
5-6 \text { feet } & \$ 2.50 \text { each }
\end{array}
$$

\section{ELII}

AMERICAN. A magnificent, stately tree, wide sweeping top. One of the most noble and grace-
ful trees where a tall, spreading tree is desired.

8 to 10 feet- $\$ 2.00$ each; $\$ 17.50$ per 10

10 to 12 feet- $\$ 2.50$ each; $\$ 22.50$ per 10

MOLINE. A valuable new type of tree perpetuated by budding. Of compact leaves of distinct dari blue-green shade. Bark smooth and glossy.

$\begin{array}{rr}6-8 \text { feet } & \$ 2.50 \text { each } \\ 8-10 \text { feet } & \$ 3.25 \text { each } \\ 10-12 \text { feet } & \$ 4.00 \text { each }\end{array}$

\section{EUONYMUS}

EUROPAEUS (European Burning Bush). A large shrub or small tree, growing to 15 feet. In spring it is covered with a wealth of bright yellow flowers in nodding clusters, followed by brilliant rose-colored berries, which the branches till midwinter. The leaves color a beautiful crmson-scarlet in fall.

$$
\begin{aligned}
& 3-4 \text { feet } \$ 1.00 \text { each } \$ 9.00 \text { per } 10 \\
& 4-5 \text { feet } \$ 1.35 \text { each } \$ 12.50 \text { per } 10 \\
& 5-6 \text { feet } \$ 1.75 \text { each }
\end{aligned}
$$

\section{FLOWERING THORNS}

CORDA (Washington Thorn). Branches up. right, forming a round topped head, leaves heart shaped. Flower white with rose-colored antlers. \begin{tabular}{ll}
$4-5$ & feet \\
$5-6$ feet & $\$ 2.50$ each \\
\hline 3.00 each
\end{tabular}

OXYACAN'IHA (Double White Thorn). Wh it flowers appealing when the leaves are nearly full grown, followed by conspicuous scarlet fruits. The foliage is very attractive and the thorny tree of regular contour.

$$
\begin{array}{ll}
4-5 & \text { feet } \\
5-6 \text { feet } & \$ 2.60 \text { each }
\end{array}
$$

\section{HONEY LOCUST}

HONEY LOCUST. This is a large, vigorous tree with leaves and strong thorns. It makes a handsome and inpenetrable heige. 6 to 8 feet- $\$ 1.50$ each.

\section{HORSE CHESTNUT}

HORSE CHESTNUT. (White Flowering) A beautiful well known tree with dark green foliage, with an abundance of showy white flowers in the early spring.

OHIO BUCKEYE

$$
\begin{aligned}
& 6 \text { to } 8 \text { feet- } \$ 250 \text { each. } \\
& 8 \text { to } 10 \text { feet- } \$ 3.00 \text { each. }
\end{aligned}
$$

\section{LINDEN}

AMERIC AN. (Basswood.) A rapid growing tree of large size. Particularly valuable for its beautiful white wood. Large shining leaves and white flowers.

EUROPEAN. A fine pyramidal tree; leaves exceedingly broad, flowers appear in the month of June. 


\section{LIQUIDAMBER}

SWEET GOM. A stately tree with narrowly ovate head, star-shaped lustrous leaves, dark green and cork bark. Its lorm is broad and pyramidal, and adapted for streets and avenues; its leaves in the spring emit a refreshing fragrance, and assume a rich crimson-scarlet in the fall. It gets its name from its fragrant sap and leaves.

6 to 8 feet; $\$ 2.50$ each.

8 to 10 feet- $\$ 3.00$ each.

\section{MAPLE}

ISH-LEAF. (Box-Elder.) Grows rapidly to a large spreading tree. It is easily distinguished by its leaves and grienish-yellow bark.

8 to 10 feet- $\$ 1.25$ each: $\$ 10.00$ per 10

10 to 12 feet- $\$ 1.50$ each; $\$ 12.50$ per 10 .

NORWA T. A handsome tree of iarge and fairly rapid growth, forming a dense rounded head of branches, and broad, deep green leaves. The best of the maples, and very desirable for street, lawn or park planting.

10 to 12 feet- $\$ 1.25$ each; $\$ 10.00$ per 10 $1 \frac{1 / 2}{}$ to $1 \frac{3 / 4}{4}$ in $-\$ 4.50$ each; $\$ 42.50$ per 10

$13 / 4$ to 2 in. $-\$ 5.00$ each; $\$ 47.50$ per 10

SCHWEILIRI. Very attractive, the foliage is of bright red and purple in the spring, a purplish green in mid-summer and golden yellow in the autumn.

6 to 8 feet-\$375 each; $\$ 35.00$ per 10

8 to 10 feet- $\$ 4.50$ each; $\$ 42.50$ per 10 .

10 to 12 feet- $\$ 5.25$ each; $\$ 50.00$ per 10 .

SUGAR OR Roci. A native tree, valuable for its production of wood and sugar.

8 to 10 feet- $\$ 2.50$ each; $\$ 22.50$ per 10

10 to 12 feet- $\$ 3.00$ each; $\$ 27.50$ per 10 .

SILVER. Hardy, rapid-growing tree, large, valuable for producing quick shade, good for street planting, foliage bright green above with silvery white beneath.

8 to 10 feet $-\$ 1.75$ each; $\$ 15.00$ per 10 .

10 to 12 feet- $\$ 2.25$ each; $\$ 20.00$ per 10

$11 /$ to $13 / 4$ inches- $\$ 2.75$ each; $\$ 25.00$ per 10

$13 / 4$ to 2 inches $-\$ 3.50$ each; $\$ 32.50$ per 10 .

WEIR'S CU'T LEAF. One of the most remarkable and beautiful shade trees with cut foliage. Rapid grower, slender and drooping. Foliage abundant green above, silver beneath.

10 to 12 feet- $\$ 3.00$ each; $\$ 27.50$ per 10 .

\section{OAK}

PIN. Almost pyramidal, and sometimes described as half weeping when old, as the lower branches nearly touch the oround. Leaves deep green, glossy ard finely divided.

6 to 8 feet- $\$ 2.25$ each; $\$ 20.00$ per 10

8 to 10 feet- $\$ 2.50$ each; $\$ 22.50$ per 10

10 to 12 feet- $\$ 3.00$ each; $\$ 27.50$ per 10 .

RED. A large tree, 80 to 100 feet tall, unusually large in leaf and quick in growth. The young shoots and leaf-stems are red, the foliage pur. plish crimson in Autumn.

$6-8$ feet $\$ 3.50$ each

$8-10$ feet $\$ 4.00$ each

$\$ 32.50$ per 10

$\$ 35.00$ per 10

$10-12$ feet $\$ 5.00$ each

$\$ 45.00$ per 10

SCARLE'T. A grand, round-topped tree with bright green deeply cut leaves that color to a sparling red in the fall.

6 to 8 feet- $\$ 3.00$ each.

\section{ORIENTAL PLANE}

EUIROPEAN SYCAMORE. Very popular for street planting. A rapid, upright, clean grower, with beautiful dense foliage: attains a large size.

8 to 10 feet- $\$ 2.25$ each; $\$ 20.00$ per 10

10 to 12 feet- $\$ 3.00$ each; $\$ 27.50$ per 10 .

$1_{1}^{1}$ to $13 / 4$ inch- $\$ 3.75$ each: $\$ 35.00$ per 10

13 to 2 inch- $\$ 4.25$ each; $\$ 40.00$ per 10

\section{POPLAR}

HOLLEANA. Rapid growing tree, pyranidal in shape, with leaves deep glossy green above and silvery white beneath.

6 to 8 feet- $\$ 1.50$ each; $\$ 12.50$ per 10 .

8 to 10 feet- $\$ 2.00$ each: $\$ 17.50$ per 10 .

10 to 12 feet- $\$ 2.50$ each; $\$ 22.50$ per 10 .

LOMBARDY. Symmetrical, pyramid-shaped head, glossy leaves. Well known for its erect, rapid growth and commanding form. Very desirable in large grounds.

8 to 10 feet $-\$ 1.00$ each; $\$ 7.50$ per 10 .

10 to 12 feet-\$1.25 each; $\$ 10.00$ per 10

\section{PURPLE LEAF PLUM}

PRUNUS I'ISSARDI. A handsome little tree covered with small white flowers in spring, latel with pinkish purple leaves which deepen in color to the end of the season. Retaining this hue bettel than most purple-foliaged plants.

4 to 5 feet-\$1.25 each; $\$ 10.00$ per 10 .

\section{TULIP TREE}

WHI'EWOOI). One of the most beautiful of our native trees. Upiright growing with heavy foliage and bright glossy leaves. Beautiful tuliplike Howers. One of the Magnolia family. It has been one of the most valuable trees in our native forest, producing the highest quality of lumber and it is one of the most beautiful trees that can be grown.

\section{6 to 8 feet $-\$ 1.75$ each \\ Weeping Trees}

The superior grace and beauty of the weeping varieties render them especially adapted to the yard, lawn or cemetery. No collection is complete without them.

BIRCH. Cut-Leaved. One of the most popular of all weeping trees; tall, slender, yet vigorous, graceful drooping habit, silvery white bark and delicately cut foliage.

4 to 5 feet- $\$ 3.00$ each.

5 to 6 feet- $\$ 3.50$ each.

6 to 8 feet- $\$ 4.00$ each

8 to 10 feet- $\$ 4.50$ each.

CHERRY. Japan Weeping. An exquisite little tree, draped in rosy masses of bloom in early spring before its leaves appear.

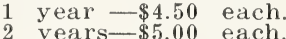

ELM. Camperdown Weeping. When well grown forms an enclosure twenty to thirty feet in diameter.

$\begin{array}{lll}1 & \text { year }-\$ 3.25 & \text { each. } \\ 2 & \text { years- } \$ 3.75 & \text { each. }\end{array}$

MULBERRY. Tea's Weeping. One of the most graceful weeping trees, forming an umbrella shaped head, with slender, willowly braluches drooping to the ground.

$$
1 \text { year- } \$ 3.25 \text { each. }
$$

WILLoW. Laurel-Leated. Vigorous, spreading upright grower, with shiny, dark gleen foliage. 8 to 10 feet- $\$ 1.25$ each: $\$ 19.00$ per 10 . 10 to 12 feet- $\$ 1.50$ each; $\$ 12.50$ per 10 . Rosmarinifolla. Medium grower with very narlow leaves, silvery underneath.

6 to 8 feet- $\$ 1.50$ each; $\$ 12.50$ per 10 .

Wisconsin Weepina. A fine drooping tree. Appropriate for planting on the banks of streams or lakes. Hard'y.

6 to 8 feet- $\$ 1.25$ each; $\$ 10.00$ per 10

8 to 10 feet- $\$ 1.50$ each; $\$ 12.50$ per 10

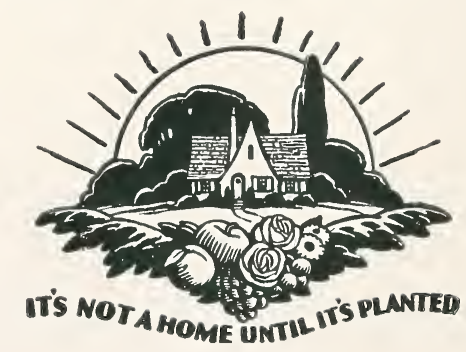




\section{Evergreens}

$\mathrm{T}$

HE stately grace of evergreen decorative plantings is indescribable. In well arranged settings they serve a year round beautification to home, lawn or estate. In foundation plantings they add beauty and distinct charm as a frame of an attractive picture. They are class itself in almost any arrangement.

During the summer season their many delightful tints of greens, blues, and yellows create wonderful effects which surpass in beauty that of other plantings. In winter there is a gradeur about an Evergreen planting that is superb. On bleak, dark days they lend their touch of color and brighten up the entire home, reflecting happiness and sunshine into one's very soul. On bright, clear, cold days they whisper of springtime and of the many surprises nature is about to unfold.

\section{ARBOR VITAE}

AMERICAN. 'The best for evergreen hedge. Grows very rapidly and can be pruned to any shape desired. Makes a dense and beautiful hedge for dividing a lawse and should not be expected to turn stock. It is also desirable for planting in clumps with other trees.

$\begin{array}{llrr} & & \text { Each } & \text { Per } 10 \\ 2 & \mathrm{ft} . & \$ 2.50 & \$ 22.50 \\ 21 / 2 & \mathrm{ft} . & 3.00 & 27.50 \\ 3 & \mathrm{ft} & 3.50 & 32.50 \\ 4 & \mathrm{ft} & 4.50 & 42.50 \\ \mathrm{~b} & \mathrm{ft} & 8.50 & 75.00\end{array}$

PYRAMIDALIS. Forms a tall slender column of dark green. Keeps a fine color all season. Hardy.

$\begin{array}{llrr} & & \text { Each } & \text { Per } 10 \\ 18 & \text { inch } & \$ 2.75 & \$ 25.00 \\ 2 & \text { feet } & 3.25 & 30.00 \\ 21 / 2 & \text { feet } & 4.00 & 37.50 \\ 3 & \text { feet } & 4.75 & 45.00 \\ 31 / 2 & \text { feet } & 5.50 & 52.50 \\ 4 & \text { feet } & 6.25 & 60.00\end{array}$

COMPAC'TA. Dwarf, rounded, dense; with leaves of light grayish green.

$$
\begin{array}{ll}
15 \text { inch } & \$ 3.00 \text { each } \\
18 \text { inch } & \$ 3.50 \text { each }
\end{array}
$$

GEO. PFABODY. Pyramidal arborritad with golden foliage, more distinct in early summer; grows twelve to fifteen $\mathrm{ft}$.

$$
12 \text { inch } \$ 2.00 \text { each }
$$

HOVEY'S GLOBOSA. Very dwarf, making a perfect globe; bright green.

$$
\begin{array}{rr}
12 \text { inch } & \$ 2.00 \text { each } \\
15 \text { inch } & 3.00 \text { each } \\
18 \text { inch } & 3.50 \text { each }
\end{array}
$$

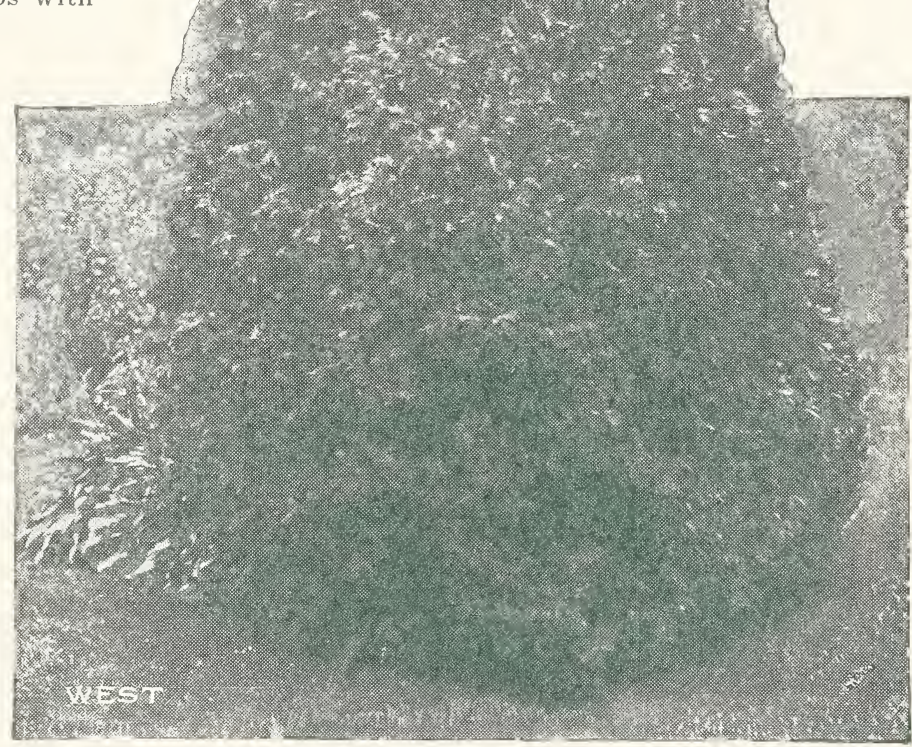

SIBERIAN. A superb hardy variety, somewhat similar to American, with heavier and fuller foliage and more compact habit; bears trimming well. This variety is extensively used for backgrounds in foundation plantings where dense bushiness is required, rather than height.

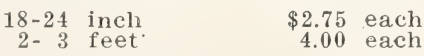

\section{JUNIPER}

IRISH. An erect, dense column of dark green found quite effective in general landscape and formal planting.

$\begin{array}{llr}2 & \text { feet } & \$ 3.00 \text { each } \\ 21 / 2 & \text { feet } & 3: 50 \text { each } \\ 3 & \text { feet } & 4.25 \text { each } \\ 4 & \text { feet } & 5.00 \text { each }\end{array}$

PFITEEIIAA. The best of all Junipers, Spleading. graceful; branches horizontal, often forming a flat, spreading cap. Blue green foliage.

$\begin{array}{llr}18 & \text { inch } & \$ 3.50 \text { each } \\ 2 & \text { feet } & 4.25 \text { each } \\ 21 / 2 & \text { feet } & 5.00 \text { each } \\ 3 & \text { feet } & 6.50 \text { each } \\ 31 / 2 & \text { feet } & 7.75 \text { each } \\ 4 & \text { feet } & 8: 50 \text { each }\end{array}$

VIRGINIANA. (Red Cedar). A well known American tree varying in habit and color, the majority being formal and bluntly conical, thicker than other upright types. The fine, dense foliage is bright blue green when fresh, maturing to deep bronze green.

$\begin{array}{rr}3-4 \text { feet } & \$ 6.00 \text { each } \\ 4-5 \text { feet } & 8.50 \text { each } \\ 5-6 \text { feet } & 13.00 \text { each }\end{array}$


JUNIPER Continued

VIRGINIANA GLAUCA (Blue Cedar). Unlike so many varieties it is not at all formal but without losing general compactness, its irregularity of spread is uniquely attractive, the broadly conical form and beautiful glaucous blue foliage nlaking it one of the choicest of all Juniper.s.

$$
\begin{array}{rrr}
3-4 & \text { feet } & \$ 8.50 \text { each } \\
4-5 & \text { feet } & 1000 \text { each } \\
5-6 & \text { feet } & 13.00 \text { each }
\end{array}
$$

SWEDISH. Of narrow, columnar form, with lighter, more bluish foliage than the Irish Juniper. Branches droop at the tips.

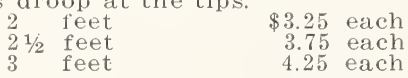

\section{PINE}

AUS'IRIAN. A remarkably robust, hardy, spreading tree of grand size, very dark and massive in effect.

$$
\begin{array}{llr}
2 & \text { feet } & \$ 3.75 \text { each } \\
21 / 2 & \text { feet } & 4.25 \text { each } \\
3 & \text { feet } & 5.00 \text { each }
\end{array}
$$

MUGHO. The only genuine dwarf pine. Leaves short stiff and formal, thickly distributed in tufts over the branches in a crowded way somewhat similar to Austrian with an equal depth and richness of color. Does not grow tail, but spreads out assuming a globular form; very dense.

$\begin{array}{rr}12-15 \text { inch } & \$ 3.00 \text { each } \\ 15-18 \text { inch } & 4.00 \text { each } \\ 18-21 \text { inch } & 5.00 \text { each }\end{array}$

SCoтCH. Dense, broadly pyramidal, luxuriant in growth, with strong elrect shoots and silvery needles.

$\begin{array}{llr}2 & \text { feet } & \$ 3.50 \text { each } \\ 21 / 2 & \text { feet } & 4.00 \text { each } \\ 3 & \text { feet } & 4.50 \text { each }\end{array}$

WHITE. Tall and stately, one of the quickest growing and longest lived. 'The needles are long and silvery blue.

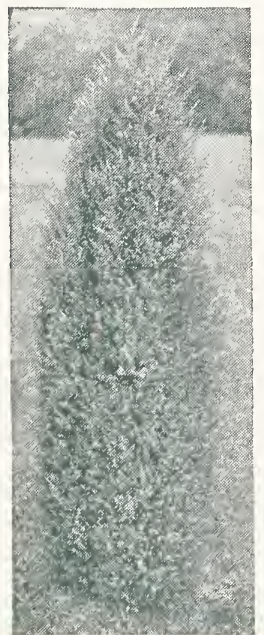

$\begin{array}{lr}5 \text { feet } & 6.50 \text { each } \\ 4 \text { feet } & 5.25 \text { each }\end{array}$

\section{RETINOSPORA}

PISIFERA. A bushỹ, rapid grower, with slende branches and light oreen leaves.

$\begin{array}{ll}18 & \text { inch } \\ 2 & \text { feet } \\ 21 / 2 & \text { feet } \\ 3 & \text { feet } \\ 31 / 2 & \text { feet } \\ 4 & \text { feet }\end{array}$

$\$ 3.50$ ea. 4.25 ea.

5.00
6.00
ea.

7.00 ea.

P I I I I IR A A UIRA. A bright golden everoreen, that holds its color: foliage light and airy. Fine for groups or specimens

$\begin{array}{llrl}18 & \text { inch } & \$ 3.50 & \text { ea. } \\ 2 & \text { feet } & 4.25 & \text { ea. } \\ 21 / 2 & \text { feet } & 5.00 & \text { ea. } \\ 3 & \text { feet } & 6.00 & \text { ea. } \\ 31 / 2 & \text { feet } & 7.00 & \text { ea. } \\ 4 & \text { feet } & 8.00 & \text { ea. }\end{array}$

\section{SPRUCE}

BLACI HILLS. The hardiest of all Spruces, symmetrical, compact and bushy in habit of growth. The foliage varies from green to bluish tint, and the trees are remarkable for their bright fresl color.

$$
\begin{array}{llr}
2 & \text { feet } & \$ 2.75 \text { each } \\
21 / 2 & \text { feet } & 3.25 \text { each } \\
3 & \text { feet } & 4.00 \text { each }
\end{array}
$$

HEMLOCK. Beautiful native evergreen. Free and drooping in growtli, but dense when pruned, forming good specimen trees, hedges or shelters. Its dark green color is retained all winter. Grows naturally to a large tree.

$$
\begin{array}{llr}
18 & \text { inch } & \$ 3.00 \text { each } \\
2 & \text { feet } & 3.50 \text { each } \\
21 / 2 & \text { feet } & 3.75 \text { each } \\
3 & \text { feet } & 4.25 \text { each } \\
31 / 2 & \text { feet } & 5.00 \\
4 & \text { feet } & 6.50 \text { each }
\end{array}
$$

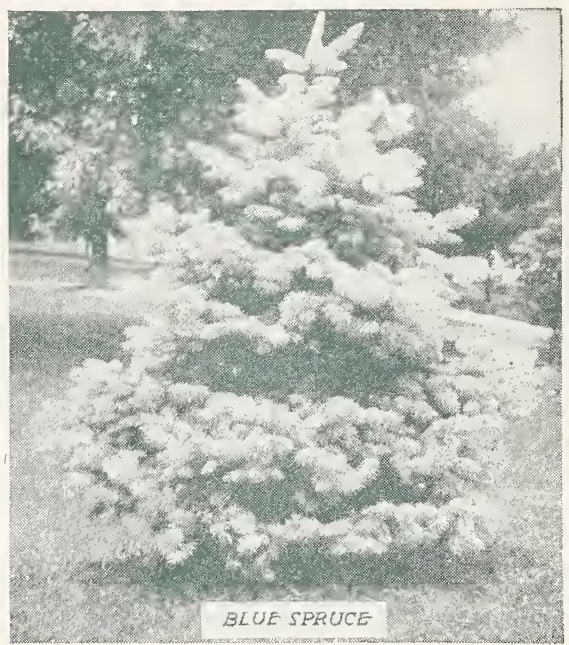

COLOBADO HLCE. A magnificent tree with foliag. of a silvery blue. Hardy and vigorous.

$$
\begin{array}{llr}
2 & \text { feet } & \$ 7.50 \text { each } \\
21 / 2 & \text { feet } & 10.00 \text { each } \\
3 & \text { feet } & 12.50 \text { each }
\end{array}
$$

COLORADO GREEN. With brilliant foliage. Hardy in any exposure and of vigorous growth.

$$
\begin{array}{llr}
2 & \text { feet } & \$ 3.75 \text { each } \\
21 / 2 & \text { feet } & 5.00 \text { each } \\
3 & \text { feet } & 6.25 \text { each }
\end{array}
$$

NORWAY. The most universally planted evergreen, for screens, hedges, windbreals and backgrounds. Perfectly hardy and easily transplanted.

$\begin{array}{llrr} & & \text { Each } & \text { Per } 10 \\ 18 & \text { inch } & \$ 2.00 & \$ 17.50 \\ 2 & \text { feet } & 2.50 & 22.50 \\ 21 / 2 & \text { feet } & 3.00 & 27.50 \\ 3 & \text { feet } & 3.75 & 35.00 \\ 4 & \text { feet } & 4.25 & 40.00 \\ 5 & \text { feet } & 6.00 & 57.50 \\ 6 & \text { feet } & 8.50 & 80.00\end{array}$

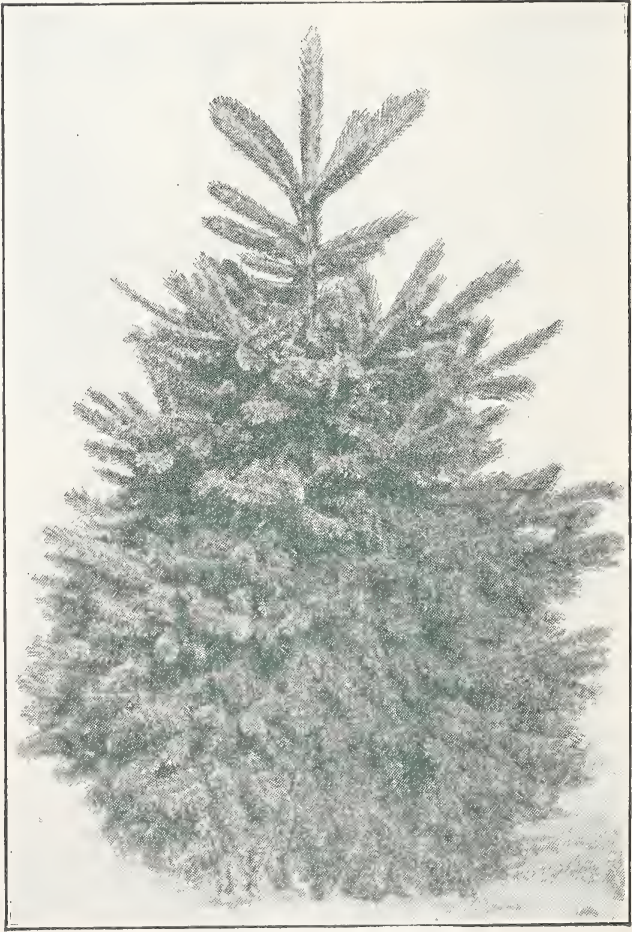

NORWAY SPRUCE 


\section{Broadleaf Evergreen Shrubs}

AZALEA. Mollis. Bushy, well branched; attractive foliage; flowers variable orange tan, yellow and red. Very hardy; good for foundation planting.
12 to 15 in
18 to 24 in.
$\$ 1.50$ each
3.00 each

LEUCO'THOE Catesbaei. (Drooping Leucothoe.) A beautiful shrub, both for blossom and foliage. The leaves, gracefully drooping branches, from which are pendant many densely packed racemes of bellshaped creamy white flowers in early May. 'The foliage is much desired for winter house decoration.

$$
\begin{gathered}
18-24 \text { inch } \\
23 \text { feet }
\end{gathered}
$$

$\$ 2.50$ each 3.00 each

\section{Hedge}

MAHONIA. Aquifolia. Beautiful evergreen shrub. Smooth, shining holly leaves; bright yeliow flower clusters in May and blue berries.

$$
\begin{array}{rrr}
15 & \text { to } 18 \text { in. } & \$ 1.00 \text { each } \\
18 \text { to } 24 \text { in. } & 1.50 \text { each }
\end{array}
$$

MAXIMLM. Foliage large and smooth. Flowers white, some being splashed with rose.

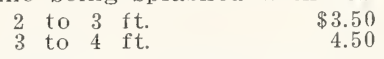

IRIODODENDRONS. Catawbiense. Attractive foliage of round shining green leaves; flowers abundant in shades of lavender and purple in early June.

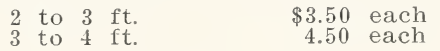

\section{Plants}

DENCES are all right to keep the cows out of the corn, but they are distinctly out of place on the home grounds. Privet or Spirea Hedge is more effective. Not only does the hedge look better than a fence but it is permanent. A hedge remains year after year, and increases in value and beauty each succeeding year. It will grow dense clear to the ground and make a tight barrier to all animals.

For quick reference we designate such plants as are used for hedging purposes. These plants have been several times transplanted and are suitable for immediate planting.

ARBOR VITAE.

(Annerican). See Evergreens.

\section{BARBERRY THUNBERGI}

Yellow flowers foliowed by scarlet berries which hang on through the winter; the green foliage changing to scarlet and gold in the fall. Makes a beautiful hedge.

$\begin{array}{rlcc}15 & \text { to } 18 \text { in. } & \text { Per } 10 & \text { Per } 100 \\ 18 \text { to } 24 \text { in. } & \$ 2.50 & \$ 20.00 \\ 2 \text { to } 3 \text { it. } & 4.50 & 30.00 \\ & & 4.50 & 40.00\end{array}$

\section{PRIVET}

A very hardy northern grown type, vigorously upright and tall growing. The leaves are dark greer but not so persistent as those of the California. Privet.

$\begin{array}{rrrr} & & \text { Per } 10 & \text { Per } 100 \\ 2 \text { to } 3 \text { feet } & \$ 2.00 & \$ 16.00 \\ 3 \text { to } 4 \text { feet } & 2.50 & 20.00\end{array}$

CALIFORNIA. 'Thick, glossy rich green leaves. Can be trimmed to any shape. Hardy.
$\div 5-18 \mathrm{in}$
i $8-24$ in
Per 10
$\$ 0.60$
.80
$\underset{\$ 5.00}{\operatorname{Per} 100}$
6.00

\section{Climbing Vines}

AMPELOPSIS VIETCHII. (Boston Ivy.) One of the finest climbers for covering walls, as it clings to smoothest surface, covering it with a niass of foliage The color is a bright green in summer, changing to bright shades of crimson and yellow in the fall. 75 cts. each; $\$ 6.00$ per 10 .

AMPELOPSIS FNGELMANII. Deeply cut leaves which turn to beautiful crimson in fall. Fine for covering trees, walls, etc. 50 cts. each; $\$ 4.00$ per 10.

ARISTOLOCHIA SIPHo. (Dutchman's Pipe.) Large leaves: brownish flower resembling a miniature pipe. $\$ 1.00$ each; $\$ 9.00$ per 10 .

CLEMATIS HENRYI. Large, creamy white flowers of fine shape. $\$ 1.00$ each; $\$ 9.00$ per 10 .

CLEMATIS JACIKMANI. Very large, velvety violet-purple flowers. Blooms continually from July until frost. $\$ 1.00$ each; $\$ 9.00$ per 10 .
IBO'TA. A fine, hardy border shrub, of spreading habit, growing 8 to 12 feet tall, with curving branches and leaves of grayish green. Its pure branches and leaves of grayish green. followed white flowels appear in June, to be followed winter.

$$
\begin{array}{ccc} 
& \text { Per } 10 & \text { Per } 100 \\
15-13 \text { in. } & \$ 2.00 & \$ 18.00 \\
18-24 \text { in. } & 2.50 & 20.00
\end{array}
$$

LODINSE. A slow growing densely compact dwalf bush, which can be used without shearing, for very low hedges and borders. It can be planied close and kept clipped down like Boxwood.

$$
\begin{array}{rlc} 
& \text { Per } 10 & \text { Per } 100 \\
9-12 \text { in. } & \$ 2.00 & \$ 16.00 \\
12-1.5 \text { in. } & 2.50 & 20.00
\end{array}
$$

VULGARIS. English.

$\begin{array}{lll} & \text { Per } 10 & \text { Per } 100 \\ 15-18 \text { in. } & \$ 2.00 & \$ 18.00 \\ 18-24 \text { in. } & 2.50 & 20.00\end{array}$

SHIREA VAN HOU'T'TE. See Shrubs.

SPRUCE. (Norway.) See Evergreens.

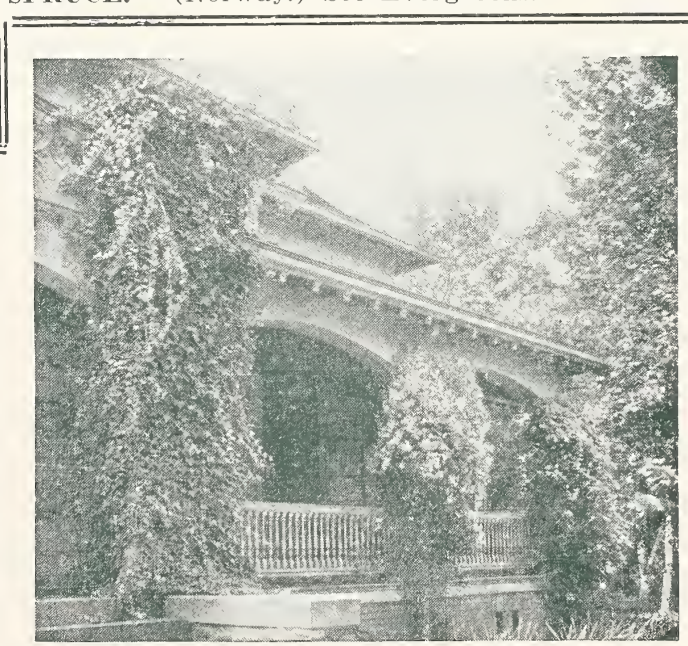

ENGLISH IVY 
CLEMATIS MADAME EDOUARD ANDRE. Very large flowers of a distinct crimson-red. $\$ 1.00$ each: $\$ 9.00$ per 10 .

CLEMATIS PANICULA'TA. A very rapid grower with nandsome, clean, glossy foliage. The flowers of medium size, fragrant, pure white produced in greal profusion in September. $40 \mathrm{cts}$. each; $\$ 3.50$ per 10 .

HONEYSUCIIE. (Hall's Japan.) Pure white changing to creamy yellow, very fragrant, in bloom the whole season. Valuable for covering banks or bare places where grass will not grow. 50 cts. each; $\$ 4.00$ per 10 .
HONEYSUCKLE. (Scarlet Trumpet.) Flowers scarlet arid trumpet shaped. $50 \mathrm{cts}$. each; $\$ 4.00$ per 10 .

CIIINESE MATRIMONY VINE. Is sometimes trained as a shrub. Purple flowers followed by showy fruit. $40 \mathrm{cts}$ each; $\$ 3.00$ per 10 .

WISTARIA MAGNIFICA. Flowers in dense drooping racemes of pale lavender. 60 cts. each; $\$ 5.00$ per 10.

WISTARIA SINESIS ALBA. Same as the above only having pure white flowers. 75 cts. each $\$ 6.50$ per 10.

\section{Deciduous}

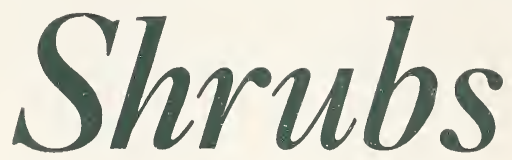

I

N CORNERS of the grounds, at curves, in the walk and driveways, and at the housc foundation are excellent places to plant shrubs. They should be in groups, unless their ultimate size will be quite large. Lilacs may be used in specimen plantings, but, low-growing shrubs, such as Barberry, the Spirea, etc., should be set in clumps. In growing it is always good policy to plant the taller growing varieties back of tho lower sorts. This gives a "step-down" effect and seems to join the house to the lawn.

IL'TIEA. (Rose of Shacon.) Blocms late in August and sepiember, with large brightly colored Howers. When planted compactly anc pruned they make a serviceable and show. hedge. Colors: Double Rose, Double Variegated Double White, Double Purple and Variegateu Leaf.

$$
\begin{array}{lll} 
& \text { Each } & \text { Per } 10 \\
2 \text { to } 3 \mathrm{ft} . & \$ 0.60 & \$ 5.00 \\
3 \text { to } & 75 & 6.50
\end{array}
$$

BUDDLEIA (Futterfly Bush) or (Summer Lilac) An altractive shrub with lilac colored flowers from early summer until frost. 3 to $4 \mathrm{ft}$ 2 to $3 \mathrm{ft}$.

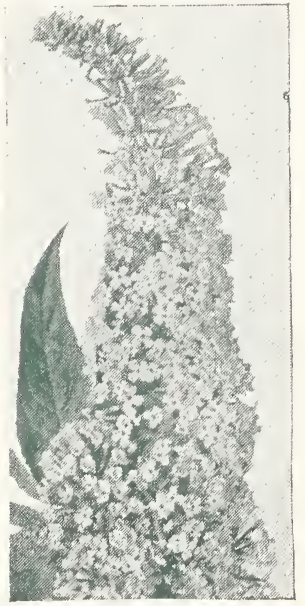

BUDDLEIA

\section{CALYCAN'THUS.}

Shrub.) Having a rare peculiar fragrance of wood and flowers. Blossoms of a chocolate red color.

$$
2 \text { to } 3 \text { ft. } .75 \quad \underset{\$ 6.50}{\text { Each } 10}
$$

CL I 'T H R.A ALNIFOLIA (Sweet Pepper Bush.) Fragrant wands of white flowers in September. 18 to 24 in. .60 Pach $\underset{\$ 5.00}{10}$ 2 to 3 ft. $\quad .70 \quad 6.00$

CORNUS. Elegantissima Variegata. Dark $\mathrm{g} r \mathrm{e}$ e $\mathrm{n}$ foliage margined with silver and red; wood a dark, purplish red.

\section{Each Per 10}

2 to 3 ft. $\quad .80 \quad \$ 7.00$

Paniculata. Medium sized bush $w$ it h finely branched stems, creamy white flowers, followed with ciusters of pearly white berries in August and September.

$$
2 \text { to } 3 \text { ft. } \quad \begin{array}{ll}
\text { Each } & \text { Per } 10 \\
\hline 0.60 & \$ 5.00
\end{array}
$$

siberica. Bright red in winter; clusters of small white flowers in early summer.

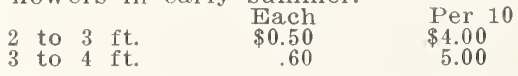

stolonifera. Large spreading shrub of rapid growtli with duli red branches in winter and round, white fruit.

$$
\begin{array}{rrrr}
3 & & \text { Each } & \text { Per } 10 \\
4 \text { to } 4 & \mathrm{ft} . & \$ 0.70 & \$ 6.00 \\
\mathrm{ft} & .80 & 7.00
\end{array}
$$

Stolonifera Lutea. A striking yellow-branched form of Stolonifera, very satisfactory for contrasting.

$$
\begin{array}{lrr} 
& \text { Each } & \text { Fer } 10 \\
2 \text { to } 3 \mathrm{ft} . & \$ 0 . .60 & \$ 5.00 \\
3 \text { to } 4 \mathrm{ft} & .75 & 6.50
\end{array}
$$

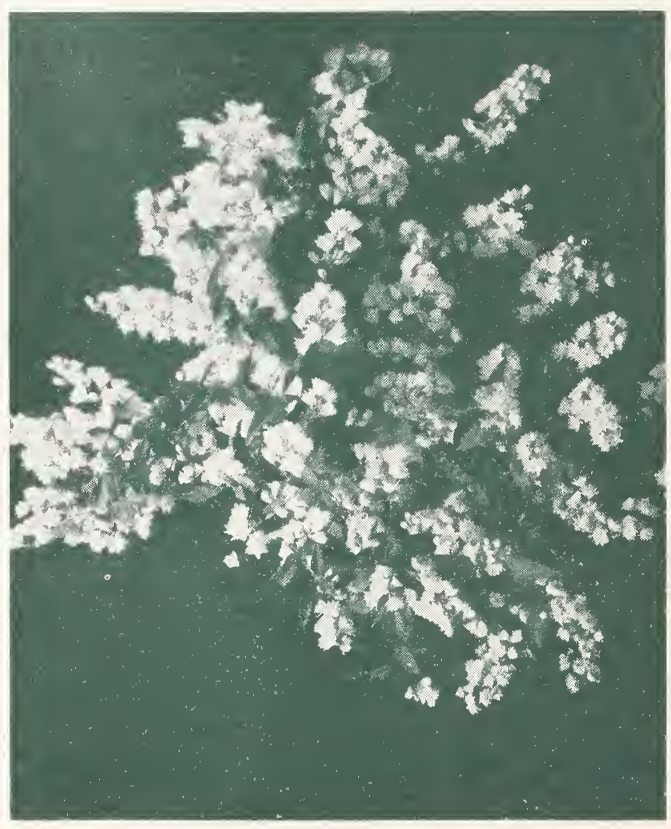

DEU'YZIA CRENATA (FI. PI.)

CYOONIA. (Japan Quince.) Hardy Shrub, double crimson flowers in early spring

$$
2 \text { to } 3 \mathrm{ft} \text {. } \$ 1.00 \text { each }
$$

DEUT'ZIA. They vary greatly in height and habit, but all have dainty bell or tassle-shaped flower borne thickly in wreaths along their branches in June.

Crenata. Beautiful white single flowered species, growing 6 to 8 feet tall.

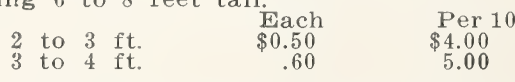

Gracilis. A dense little bush rarely over two feet high, that blooms in May. Pure white flowers.

$$
\begin{array}{llcc} 
& & \text { Each } & \text { Per } 10 \\
15 \text { to } 18 \text { in. } & .50 & \$ 4.00 \\
18 \text { to } 24 \text { in. } & .60 & 5.00
\end{array}
$$

Lemoinei. Rarely growing over three feet high with spreading branches, bright green leaves, white flowers in large clusters.

$$
2 \text { to } 3 \mathrm{ft} . \quad \begin{array}{ll}
\text { Each } & \text { Per } 10 \\
.80 & \$ 7.00
\end{array}
$$


DEUTSIA Continued

Pride of Rochester. This variety grows six to eight feet tall. The white flowers are large and double

$\begin{array}{cccc}2 & & \text { Each } & \text { ver } 10 \\ 3 \text { to } 3 \mathrm{ft} . & .50 & 1.00 \\ & & .50 & 500\end{array}$

Hosea. Rose colored flowers.

$$
\begin{array}{llcc}
2 & & \text { Each } & \text { Per } 10 \\
3 & \text { to } 3 \text { ft. } & .50 & \$ 4.00 \\
\text { to } 4 \text { ft. } & .60 & 5.00
\end{array}
$$

EIDER. Cut Leaf. Fragrant white flowers in June and July, followed by large clusters of fruit.

$\begin{array}{cccc}2 & & \text { Each } & \text { Per. } 10 \\ 3 & \text { to } 3 \mathrm{ft} . & .60 & \$ 5.00 \\ 3 & \text { to } 4 \mathrm{ft} & .70 & 6.00\end{array}$

Golden. Handsome with golden yel low leaves, valuable for enlivening shrubbery. Can be pruned into a neat, compact little bush, or grows naturally from ten to fifteen feet high.

$$
\begin{array}{cccc}
2 & & \text { Each } & \text { Per } 10 \\
3 \text { to } 3 \mathrm{ft} . & .60 & \$ 5.00 \\
\mathrm{ft} . & .70 & 6.00
\end{array}
$$

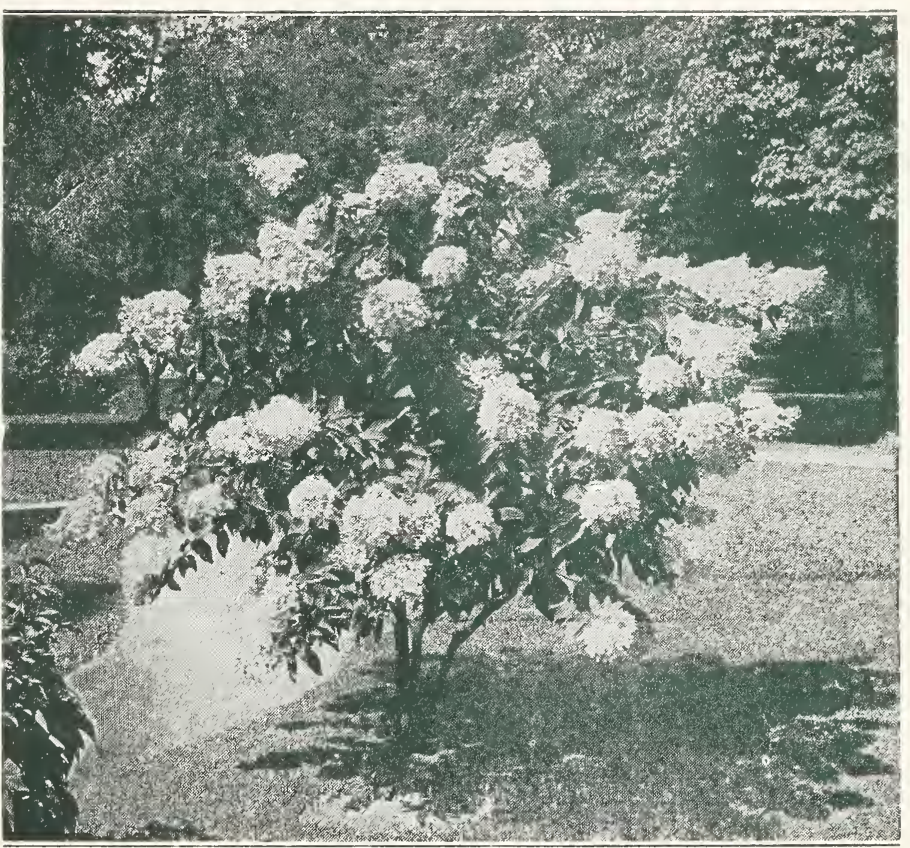

HY DRA NGEA

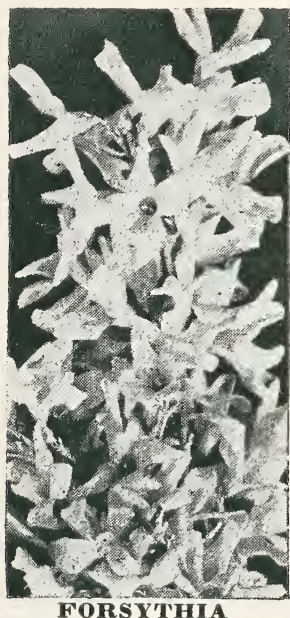

HONEYSUCKLE-
FORSY'THA (Golden Bell.) Masses of yellow bell-shaped flow ers in the early spring before the leaves appear. Per fectly hardy.

2 to $3 \mathrm{ft} . \quad .50 \quad \$ 4.00$

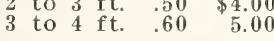

Fortunei. Strong grow ing, erect branches.

Intermedia. Blooms very early. Slender, arching branches.

Spectabilis. Of $\mathrm{I} n \mathrm{t}$ e $\mathrm{r}$ media Character, with very broad heavy flowers.

Suspensa. Long, curving branches used fol covering arches and trellisses.

$\begin{array}{ll}\text { Each } & \text { Per } 10 \\ .50 & \$ 4.00 \\ .60 & 5.00\end{array}$

Tartarian. Pink, red or white flowers, followed by red or orange berries.

Bella Albida. About six feet tall, with clusters of fragrant white flowers, followed by bright red berries, which cling all summer. Very handsome.

Bella Roser. Similar to the Albida, but with rose colored flowers.

Fragrantissima. Distinguished by its small, round leathery leaves showing the darkest shade of green, which are practically evergreen if in a sheltered position. Also its very early clusters of tiny pink and white flowers are sweetly fragrant, their scent even clinging to wood and foliage.

Morrowi. Grows only about four to five feet tall spreading. Pure white flowers in early spring. with brilliant red fruits in August, which are persistent through the fall.

Morrowi Red. Similar to the above but witlı red flowers.

Xylosteum. Yellow flowers in May followed by Red Berries which persist during most of the summer.

\section{HYDRA N GEA-}

$$
\begin{array}{ccc}
18-24 \mathrm{in} . & \text { Each } & \text { Per } 10 \\
2 \text { to } 3 \mathrm{ft} . & .60 & \$ 5.00 \\
\hline & 70 & 6.00
\end{array}
$$

Arborescens. Large white flowers in July and August, which resembles
Paniculata Grandiflora. Massive plumes of white flowers which change to pink and bronze green Perfectly hardy. One of the most effective shrubs

Paniculata Grandiflora. Tree shape.

$$
\begin{aligned}
& 3 \text { Grandifiora. Tree shape. } \\
& \text { to } 4 \text { it. }
\end{aligned}
$$

LILAC. Common Purple, Old-Fashioned s we tscented lilac of our childhood. Their fragrance should bless every home.

$$
\begin{array}{ccc} 
& \text { Each } & \text { Per } 10 \\
2 \text { to } 3 \mathrm{ft} . & .50 & \$ 4.00 \\
3 \text { to } 4 \mathrm{ft} . & .60 & 5.00
\end{array}
$$

Purple Grafted.

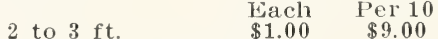

Alphouse Lavelle. Violet blue.

Ludwig Spaeth. Dark blue.

Belle de Naney. Satiny rose with white center.

La'rour d'Auvergme. Dark double red.

Mad. A. Chateney. Snow white.

Monument Carnot, Pale Lilac.

Persian. Purple and white, dwarf growing.

Pres. Grevy. Double blue.

Villosa. Dwarf, broad-leaved, It has pink flowers.

PHILADELPHUS Aurea. A medium sized shrub with golden foliage that remains bright through the season. Valuable for contrastive planting.

$$
\begin{array}{lrl} 
& \text { Each } & \text { Per } 10 \\
15 \text { to } 18 \text { 1n. } & .75 & \$ 6.75
\end{array}
$$

Coronarius. (Garfield Syringa.) Early bloomer, its oronarius. (Garfere lightfully scented.

$$
\begin{array}{cccc} 
& & \text { Each } & \text { Per } 10 \\
3 & \text { to } 3 \mathrm{ft} . & .50 & \$ 4.00 \\
3 \text { to } 4 \mathrm{ft} & .60 & 5.00
\end{array}
$$

Gordoniauus. Strong growing; large white flowers

$$
\begin{array}{rcc}
\text { late in July. } & \text { Each } & \text { Per } 10 \\
2 \text { to } 3 \mathrm{ft} . & .50 & \$ 4.00
\end{array}
$$

Grandiflorus. Vigorous; its long irregular branches are clustered with large slightly fragrant flowers in June.

$$
\begin{array}{lll}
2 & \text { Each } & \text { Per } 10 \\
3 \text { to } 3 \mathrm{ft} . & .50 & \$ 4.00 \\
3 \text { to } 4 \mathrm{ft} & .60 & 5.00
\end{array}
$$

Virginalis. A magnificent new variety. Moderately tall, with good foliage and compact habit. The flowers are the largest, handsomest, and most sweetly fragrant of any known variety, with longest blooming season.

$$
\begin{aligned}
& 18 \text { to } 24 \text { in. Each Per } 10 \\
& 18 \text { to } 24 \text { in. } \quad .50 \quad \$ 4.00
\end{aligned}
$$




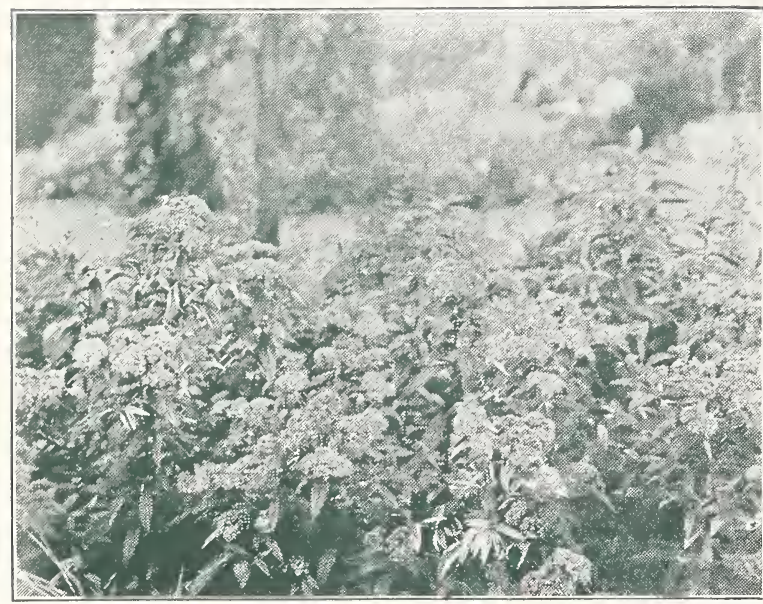

SHIREA ANTHONY WATERER

RHODOTYPPOS Kerrioides (White Kerria). An attractive rounded shrub 3-6 feet high, with beautiful yellowish green, corrugated foliage and large, single white flowers late in May, cause it will endure partial shade.

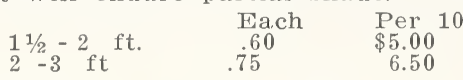

SPIREA Anthony waterer. M a k s a low compact bush, covered nearly the whole season with bunches of small deep crimson flowers.

$$
\begin{array}{rrr} 
& \text { Each } & \text { Per } 10 \\
15 \text { to } 18 \mathrm{in.} & .50 & \$ 4.00 \\
18 \text { to } 24 \mathrm{in.} & .60 & 5.00
\end{array}
$$

Arguta. A slender, upright shrub, 3 to 5 feet high, with branches a snowy mass of clear white flowers in early May.

$$
\begin{array}{rcc}
18 \text { to } 24 \mathrm{in} . & \text { Each } & \text { Per } 10 \\
2 \text { to } 3 \mathrm{ft} . & .60 & \$ 5.00 \\
& .70 & 6.00
\end{array}
$$

Aurea. Leaves bright yellow in spring, gradually changing to golden bronze in fall. Clusters of white flowers in June.

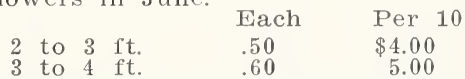

Billardi. A narrow dense shrub six feet in height, with dense panicles of rich pink flowers in July and August.

$$
\begin{array}{llll}
2 & & \text { Each } & \text { Per } 10 \\
3 & \text { to } 3 \mathrm{ft} . & .50 & \$ 4.00 \\
3 \text { to } 4 \mathrm{ft} & .60 & 5.00
\end{array}
$$

Bumalda. A spreading low bush about two feet high with dark leaves brightened by clusters of light pink flowers in May.

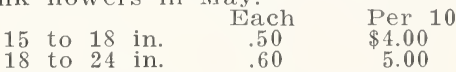

Callosa Alba. Of compact growth four feet higl with upright branches and bluish foliage, flowers nearly all sumnier.

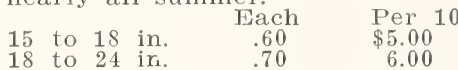

Douglasi. Upright in growth to about five feet. Bears spikes of deep rose colored flowers in July and August.

$$
\begin{array}{lll}
2 & \text { Each } & \text { Per } 10 \\
3 \text { to } 3 \text { ft. } & .50 & \$ 4.00 \\
\text { to } 4 \text { ft. } & .60 & 5.00
\end{array}
$$

Opuliflora. Very strong growth, clusters of white flowers in June.

$$
\begin{array}{lll} 
& \text { Each } & \text { Per } 10 \\
2 \text { to } 3 \mathrm{ft} . & .50 & \$ 4.00 \\
3 \text { to } 4 \mathrm{ft} & 60 & 5.00
\end{array}
$$

Prunifolia. (Bridal Wreath.) Very early bloomer. Its rraceful branches are covered nearly their whole length with smill double white flowers

$$
2 \text { to } 3 \mathrm{ft} . \quad \begin{array}{lll}
\text { Each } & \text { Per } 10 \\
\hline 6.50 & .75 & \$ 6.5
\end{array}
$$

Reevesiana. Narrow, pointed leaves, and round clusters of white flowers in June.

$$
\begin{array}{llll}
2 & \text { Ea } 3 \mathrm{ft} . & .50 & \mathrm{Per} 10 \\
3 \text { to } 4 \mathrm{ft} & 60 & \$ 4.00 \\
& & & \mathbf{5 . 0 0}
\end{array}
$$

Thumbersi. Dense feathery foliage changing to bright red and orange in fall. Flowers pure white.

$$
\begin{array}{rrrrr}
18 \text { to } 24 \text { in. } & \text { Each } & \text { Pœr } 10 \\
2 \text { to } 3 \text { ft. } & .60 & \$ 5.00 \\
& & .70 & 6.00
\end{array}
$$

\section{VAN HOLTTE}

Is covered in May with small white flower n clusters, presenting a beautiful appearance. It is very hardy and one of the finest shrubs in cultivation.

$$
\begin{aligned}
& 2 \text { to } 3 \mathrm{ft} \text { Each Per } 10 \\
& \begin{array}{llll}
\mathrm{t} n & \mathrm{ft} & .50 & \$ 4.00
\end{array}
\end{aligned}
$$

SYMPHORICARI'OS. Racemosus. (Snowberry.) Flowers are inconspicuous, rose-colored, in June and July; leaves thin, dark, green; fruits large, milk-white, clustered, persistent until late in the wirter.

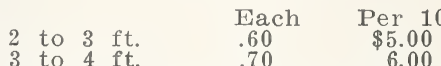

Vulgaris. (Indian Currant or Coral Berry.) Similar to the Snowberry, except that the fruit is red and clusters about the stem in thick ropes.

$$
2 \text { to } 3 \mathrm{ft} . \quad \text { Each } \quad \text { Per } 10
$$

VIBURNUM. Dentatum. Bright green, heart-shaped leaves tul'ning to purple and red. May and June flowers of creamy white.

$$
\begin{array}{rlcc}
18 & \text { to } 24 \mathrm{in.} & \text { Each } & \text { Per } 10 \\
2 & \text { to } 3 & .50 & \$ 4.00 \\
& .60 & 5.00
\end{array}
$$

Carlesii. Produces delicate, spice-scented flowers in May and June. The buds before expanding are an attractive pink developing into Bouvardiaan attractive pink, developing into Bouvardiatheir perfect f pure white. Flowers preserve their perfect form and purity of color and unusually long time. The bush is rounded, slow growing to four feet with oroadly oval leaves, on both sides, autumn painting them luxuriantly.

$$
\begin{array}{rr}
12-15 \text { in. } & \$ 2.00 \text { each } \\
15-18 \text { in. } & 2.75 \text { each }
\end{array}
$$

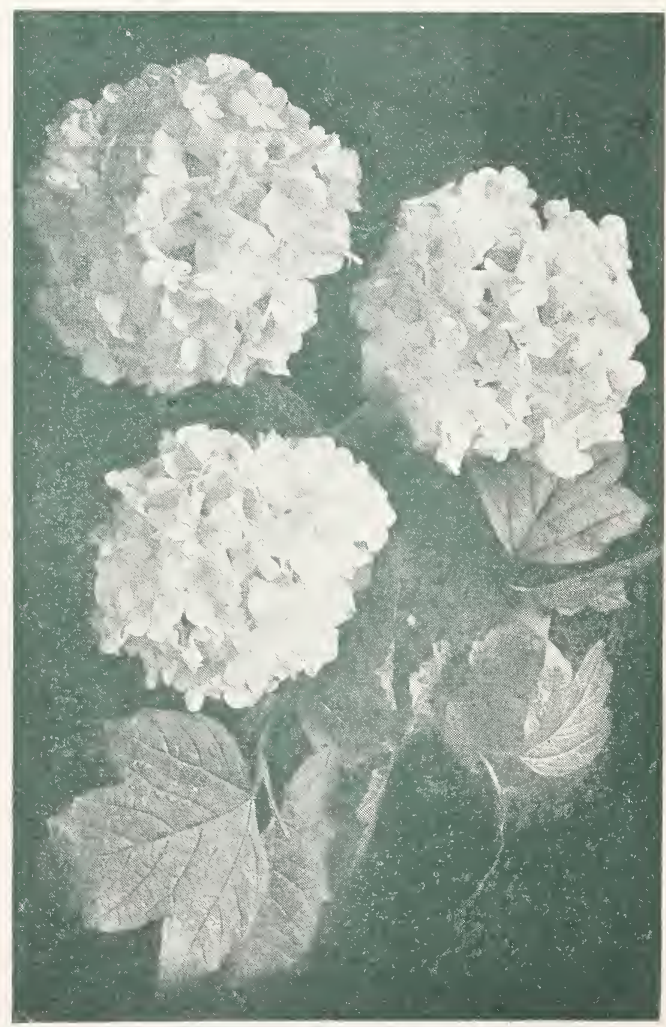

VIBUIN UM OId Fashioned snowbal 


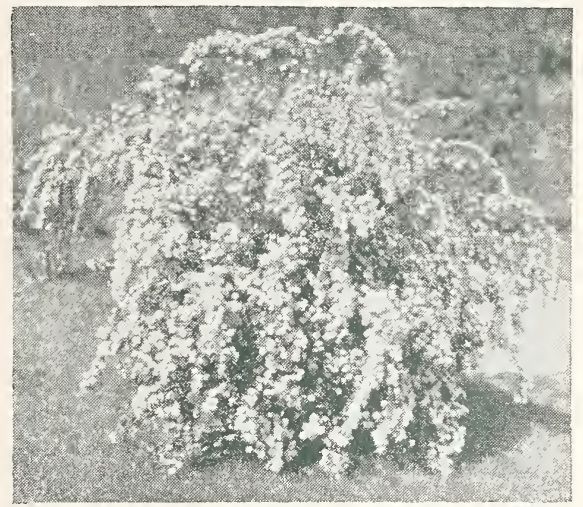

SPIREA VAN HOUTTE

IBLIENM - Continued.

Lantana. (Wayfaring Tree) 10-15 feet. Beautiful wrinkled, Lantana-like leaves; white flower's in May and June. Fruits color unequally from crimson to black, causing a most charming combination of colors, throughout the summer.

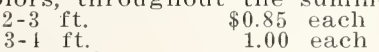

Opulus. (High Bush Cranberry.) Grows from eight to ten feet high, with white flowers in May, followed by beautiful showy clusters of scarlet lowed

$$
2 \text { to. } 3 \text { ft. } \quad \begin{aligned}
& \text { Each } \\
& \text { Per }
\end{aligned} 10
$$

Plicatum. Vigorous, upright grower, with deep green foliage and white balls of bloom in June.

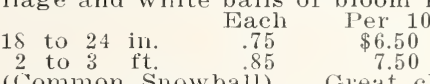

sterile. (Common Snowball). Great clusters of white flower's in May. Fach Per 10

$$
2 \text { to } 3 \mathrm{ft.} \quad \text { Each Per } 10
$$

Tomentosum. Dark, heavily veined leaves, panicles of tlat, white flowers, followed by red fruit, changing to bluish black.

$$
\begin{array}{rrrr}
18 & & \text { Each } & \text { Per } 10 \\
2 \text { to } 3 & \mathrm{in} . & .60 & \$ 5.00 \\
2 \text { t. } & .70 & 6.00
\end{array}
$$

WEIGELIA. (Abel Carrier.) Flowers are rose-carmine with ycllow spot in the throat.

$$
\begin{aligned}
& 2 \text { to } 3 \mathrm{ft} \text { Each Per } 10
\end{aligned}
$$

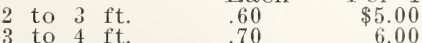

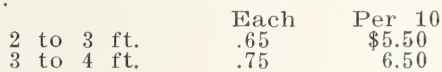

\section{ROSES}

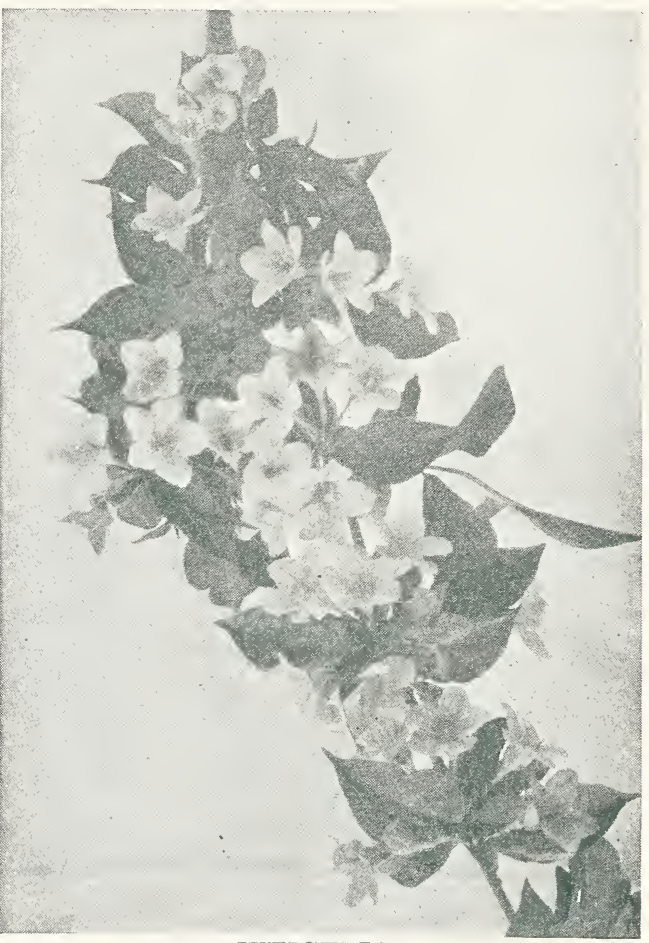

WEIGELIA

Eva Rathke. Flowers of a dark carmine red in

$$
2 \text { to } 3 \text { ft. } \quad \begin{array}{cc}
\text { Each } & \text { Per } 10 \\
\$ 1.00 & \$ 9.00
\end{array}
$$

Rosea. Rose colored blossoms in July.

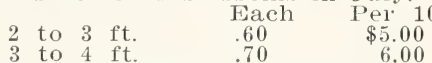

Van Houtte. Flowers flat, broad, deep rosy red

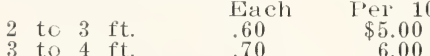

varicanta. Leaves are broadly margined with creamy white, pink flowers.

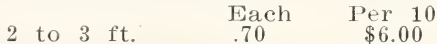




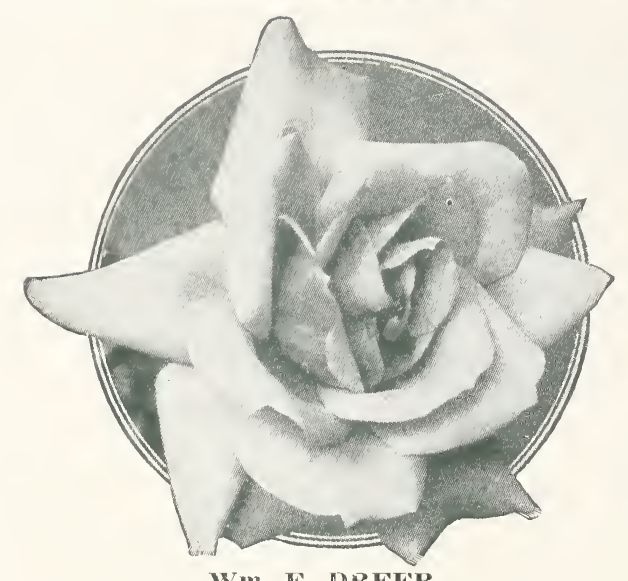

Wm. F. DREER

HYBRID PERPETUAT ROSES (Continued)

ULRICH BRUNNER. A splendid upright grower, bright healthy foliage. An abundant bloomer Bright cherry red.

\section{Hybrid Tea Roses}

These are noted for their exquisite form, delicate shadings of color, delightful perfume and perpetual blooming; buds and flowers are produced at the terminal of every shoot; so it is only necessary to keep the plant growing thriftily to get bloom; not keep the plant growing thriftily to get bloom; not well worth the extra protection and care required.

\section{All Varieties 2 Years
$\$ 1.00$ Each: $\$ 9.50$ per 10}

FTOILE DE FRANCE. Intense brilliant crimson flowers on long, strong stems, very fragrant and free blooming.

GENERAL McAIRHUR. Deep, velvety scarlet strong grower and a profuse bloomer; one of the best scarlet varieties.

GORGEOUs. Flowers large and full, exquisitely formed and borne in great profusion. Deep orang yellow, Hushed coppery yellow and heavily veined with coppery red.

F. J. GROO'TENDORST. Typical rugosa foliage, health and habit of compactly bushing moder ate growth; but revealing its baby rambler cross derivation in the form, color and season of it. bloom. Not only suitable for association with medium shrubs like other rugosas, but on account of its character, deserves more prominent exhibition, either as a single specimen or in a separate massed group. The bloom is in clusters of over-sized, fairly double red flowers resembing the Crimson Baby Rambler, which like type produces from early summer until fall. $\$ 1.25$ ea.

GRUSS WN TEPLITZ. Bright scarlet-crinson growing freely and blooming profusely. Quite hisldy.

M. V. MACHIN. Intense scarlet-crimson; blackstained and velvety; large, full and high cen tered. "This is one of the richest colored of the led everbloomers.

J. I. L. MOCI. Very large, full, and fragrant; petals silvery, rosy white inside, outside carminepink.

is. A. VICtORIA. Full double fowers; delicate creamy white; deliciously fragrant

FULABNEY Exquisite form and ragrance. Bright pink marbled in white. Buds very long.

IILLARNEY WHITE. Similar to Killarney, except color, which is a creamy, often nearly pure white.

LADY HILLINGDON. A deep apricot yellow, beautiful in bud and flower.

LAFIRANCE: Peach-blossom pink, clouded with rosy flesh. Flowers very large and highly perfumed

LoS INiELES. Brilliant flame-pink, toned with coral and shaded with gold at the base of the petals. Buds are long and pointed.

MME. ABEL CHATEIAY. Carmine-rose, shaded with salmon.

MAD. JULFS BOCCHE. A beautiful shade of white, overlaid and blended with salmon pink.

MME. CAROLINE TESTOUT. Brilliant clear pink. deepering at center, and bordered silvery rose. MME. EDOUARI HERRIOTT. Coral-red, shaded with yellow and bright rosy scarlet
MRS. AARUN WARD. Buds long and shapely, opening cup shape; color, Indian yellow shaded salmon rose.

UIRS. A. R. WADDELL. Long and pointed buds of rosy scarlet, openirg coppery salmon. A continuous bloomer

Ol'HEI.I. One of the most beautiful and populal with perfect flowers of distinct form, lavishly produced; white, tinted and shaded with salmon flesh. 10 se and yellow.

RADIANCE. Hardy, vigorous and prolific. A beautiful blending color of carmine-rose with shades of opal and copper.

rOSA RUGOSA. (F. J. Grootendorst) A typical rugosa rose. Bloom closely resembles crinison rugosa rose. Bloom closely resembles crinison sunimer until fall. $\$ 1.25$ each.

SOUV. DE CLAIDIUS PERNE'T. Most satisfactory yellow rose ever produced. A decided and comparatively unfading sun-yellow even deeper paratively unfading sun-yellow even deeper with elongated petals; the buds long and with elongated petals; the buds long and brariching, with brilliant foliage and almost thornless stems.

WI. F. DREER. Silver shell-pink petals, the base of each being rich yellow. Flowers large, double, and a profuse bloomer.

\section{Polyantha Roses}

\section{(BABY RAMBLER}

75 Cts. Fach; $\$ 7.00$ Per 10

BAIY RAMBLER. A type of rose which is very popular for beding purposes. They form shapepopular for beading purposes. They form shapehigh, producing in great profusion from early in the season until severe frost, immense trusses of small flowers. Pruning is not necessary; simply remove the past season's flower stems. brighi crimson color.

GRNA 'IESCHENDORF', Deep, unfading crimson, more dependable than the common Baby Rambler.

ROSA RUGOSA. A valuable and perfectly hardy rose much used for landscape work; lustrous dark green foliage; is impervious to the attack of insect pests. Its single, highly scented flowers are followed by large, handsome scarlet fruits, persistent into the winter.

ALBA. Pure white.

RUBRA. Rosy crimison.

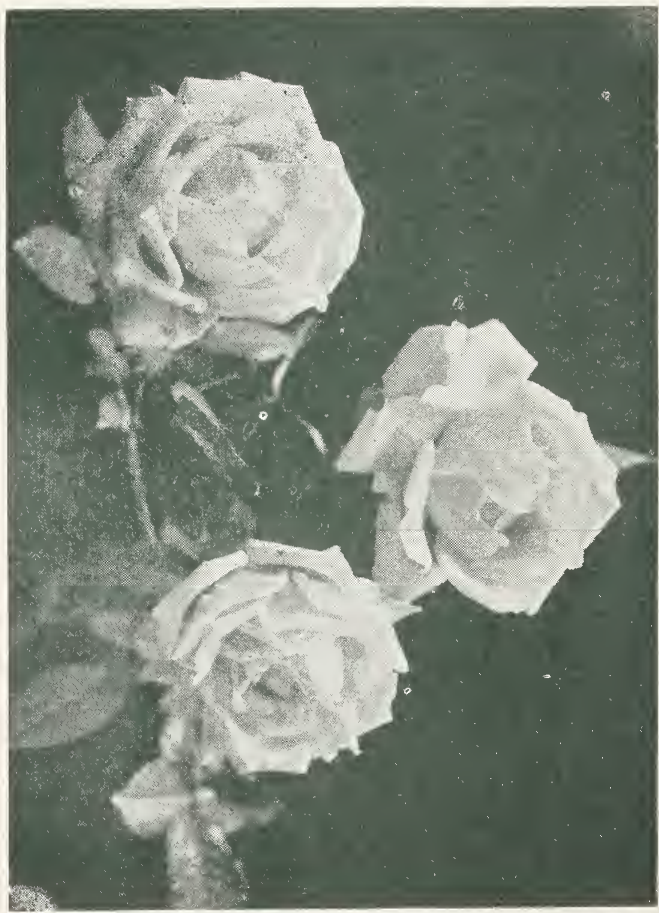

GRUSS EN TEPIITS 


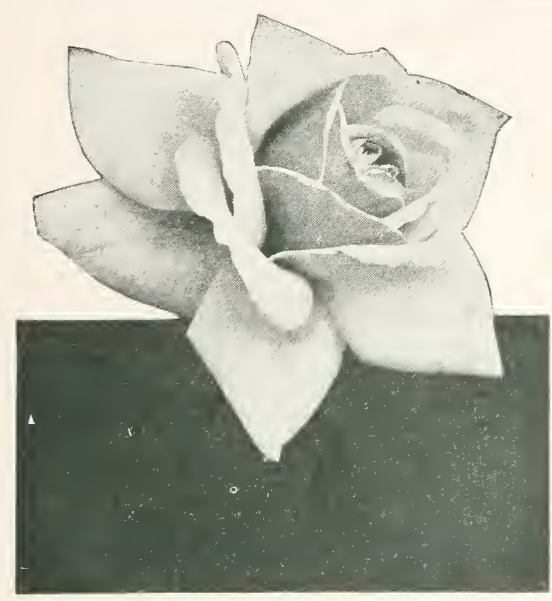

J. J. L. MOCK

\section{Tree Roses}

The Tree Roses are grafted on hardy stems 4 to 5 feet high, and thus form tree shapes. When in full bloom they are very handsome and popular for formal gardens. $\$ 2.00$ each; $\$ 17.50$ per 10.

In these we offer the following varieties:

ERNA TUSCHENDORF.

GRUSS EN TEPLITZ.

IRS.J. H. LAING.

PINIK IKILI.ARNEY.

FRAU KARL DRUSCHKI.

\section{Climbing Roses}

All Varieties 75 Cts. Each; $\$ 6.00$ Per 10 CRIMSON RAMBLER. The beautiful crimson clustered climber. Makes shoots from eight to ten feet long in a season. The best known climbing rose.

DOROTHY PERKINS. A beautiful shell-pink rose, having the same strong habit of growth as the Crimson Rambler. Very double, sweetly scented, and perfectly hardy.

DR. VAN FLEE'T. A mass of beautiful clustered buds, which open out into large shapely solitary flowers with stems 12 to 18 inches long; delicat flesh white.

EXCELSA. Tery deep pink, type of Dorothy Perkins.
FLOWER OF FAIRFIELD. One of the best of the newer varieties, flowers of a fine crimson color. The growth is vigorous, flowering freely and continuously throughout the entire season. PAUL'S SCAILE'T CLIMIBER. Vivid Scarlet. New. WHITE DORO'THY l'ERIKINS. Similar to Dolothy Perkins but white.

Roses thrive best in a medium light clay soil. Before planting prepare the soil by spading thoroughly and working over to a depth of about 18 inches, fill in well rotted stable manure while spading and work it carefully into the soil. After the plants are set, for best results cut all branches back to within 3 to 4 inches of the top of the ground The new growth coming out will make a much nicer head than if the plant were not pruned, and the bushes will bloom better.

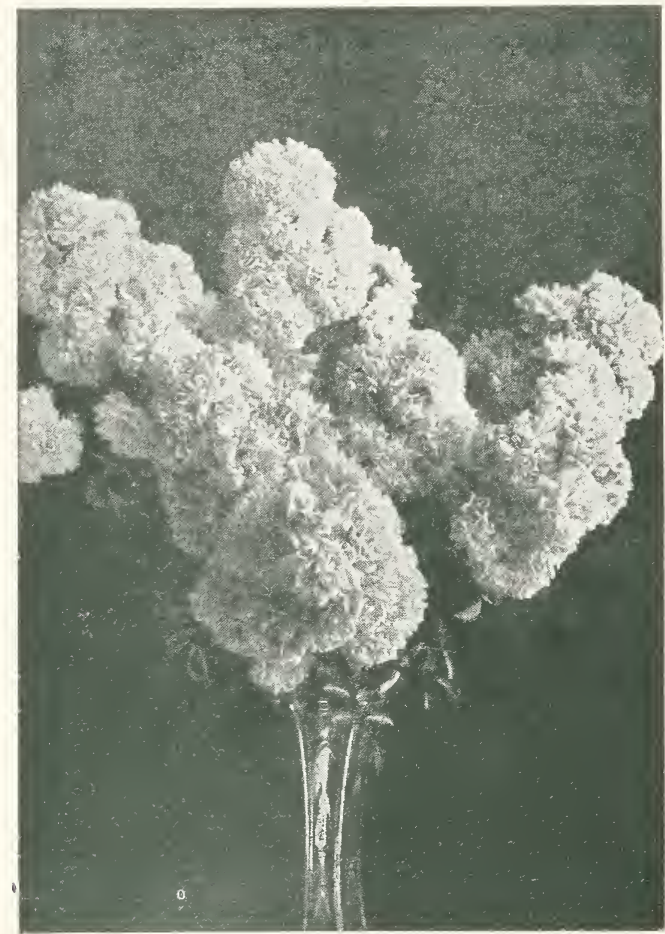

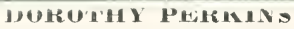

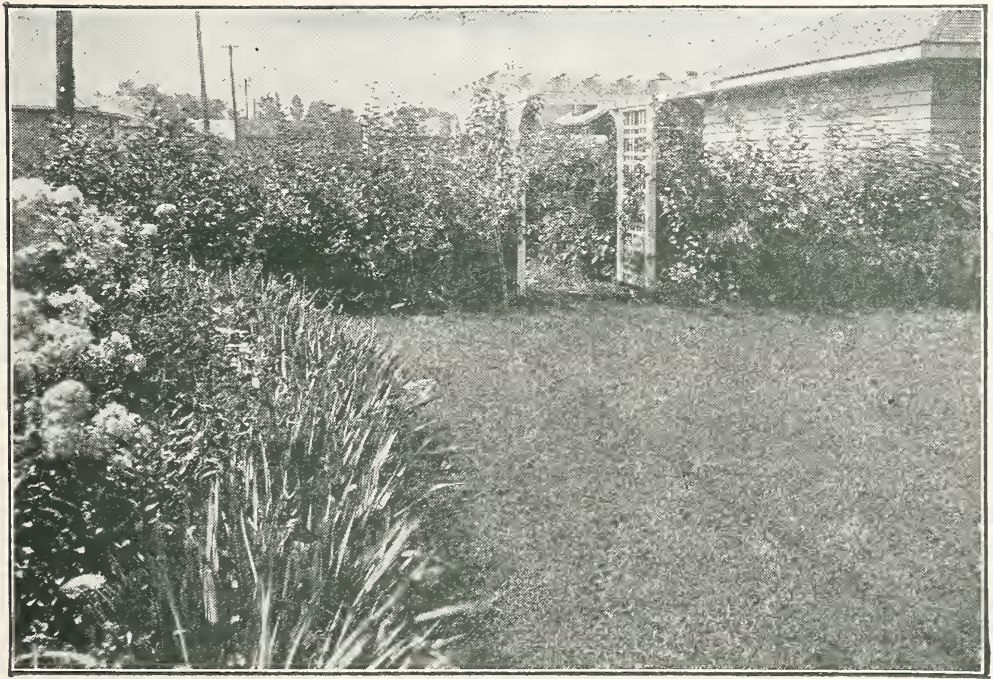

\section{Plant Hardy Flowers}

No true lover of neglect the of the Hardy Perennials.

A back yard planting is a most interesting plaything. New flowers coming into bloom continually produce a variety of color effects that is a new revelation from day to day.

You won't grow old so fast if you develop a hobby of flowers. 


\section{Peonies}

T F people only knew how simple and easy it is to grow beautiful Peonies every lawn and garden would have a collection of the various kinds and colors. Peony bloom rivals the Rose in beauty and is much larger, which makes it the flower for beautifying the home lawn, house and store decoration and annual remembrance on the graves of your dead. The greatest advantage is that the plants and bloom are free from insect pests and do not have to be persuaded to bloom. Their bright colors and pleasing fragrance captivate people of every age, condition, location and race. In size they range from four to eight inches in diameter, some small and dainty, others massive and fluffy as any chrysanthemum, and a great many with a fragrance as charming and delicate as a rose. The modern Peony is certainly a marvel.

\section{PEONY PRICAS}

40 els. each; $\$ 3.50$ per 10

AIBER'T CROUSSE. Late. Immense, perfect in shape. Delicate sea shell pink.

$\$ 1.00$ each; $\$ 9.00$ per 10

CARNATION. Red, very handsome, a free bloomer, very fragrant.

DUCHESS DE NEMOURS. Pure white, with sulphur-white collar. Fragrant. Vigorous grower and free bloomer.

FOULIS SUPERB.. Very early; in full bloom liay 30 th. Beautiful bright clear pink with silvery leflex. June rose fragrance.

$$
50 \mathrm{c} \text { each; } \$ 4.50 \text { per } 10
$$

ENER. Flesh pink, chrysanthemum center, a heavy bloomer, very pietty.

FELIX CROUSSE. Late mid-season. Rose type; solid and compactly built; a rich brilliant ruby red.

$\$ 1.00$ each; $\$ 9.00$ per 10

FES'TIVA MAXIMA. Enormous flowers, clear white with an occasional carmine red spot on the edges of center petals. Handsome.

MONS JULES ELIE. Early mid-season. Very full flowers, glossy lilac-pink, shading into deepel rose at base Fine for cut flower's. $\$ 1.00$ each; $\$ 9.00$ per 10

Po'I'ISII. Dark red, yellow stamin, very attractive.

ROSE FRAGRANS. Deep rose color, very fragrant, strong, free bloomer.

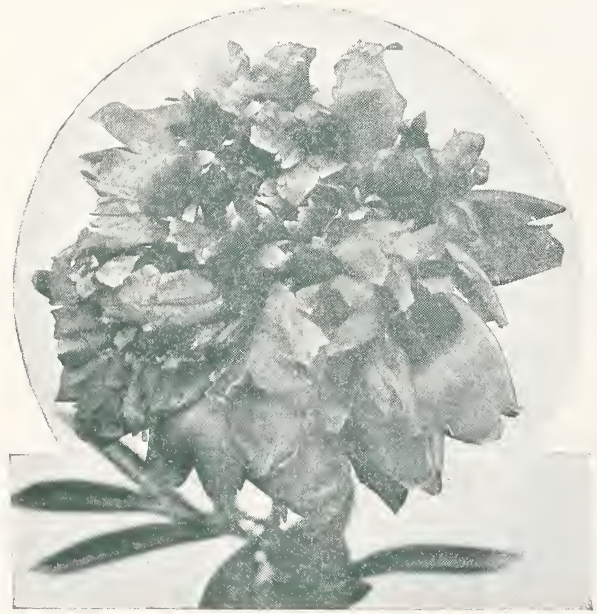

NIGRA

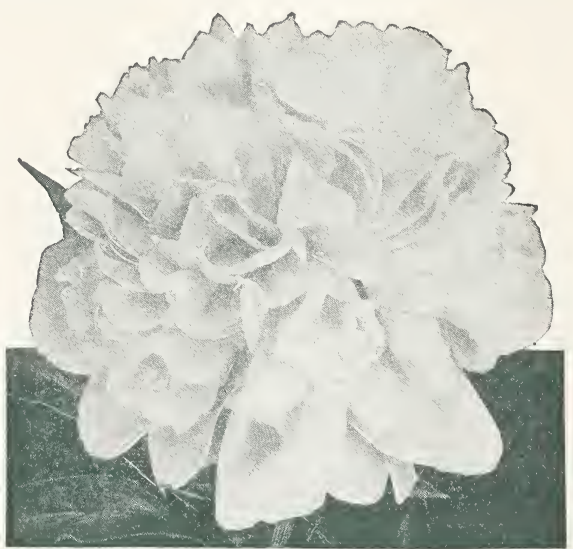

FESTIVA MAXIMA

TERRY's No. 1. Deep pink outer petals, flesh center, pretty.

GIRANDIFI,ORA. Deep rose color, almost red, very fine.

JULI'Tlik. Double pink, very handsome, strong free bloomer.

MRS. FLE'TCHER. Double pink, very pretty.

NIGRA. Dark red, very pretty.

OLIVE LOGAN. Rose pink, white center, handsome.

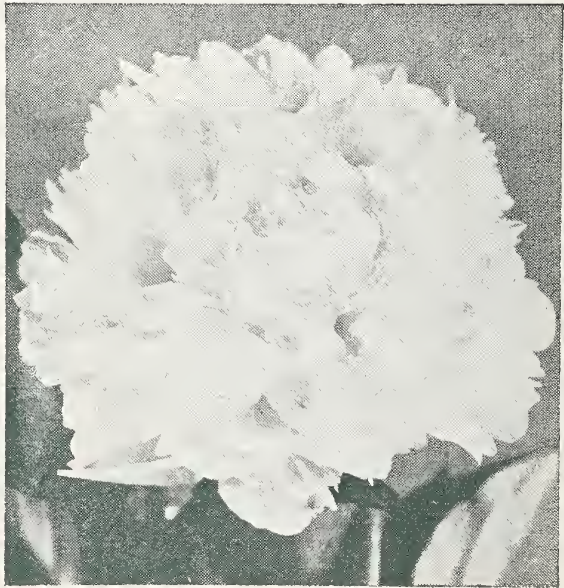

ALBERT CROUSSE 


\section{Hardy Perennial Plants}

T $\mathrm{N}$ our offering of hardy plants we have selected varieties which can be grown satis1 factorily by the amateur and which thrive in a large variety of soils. These can be used to best advantage in groups and beds on the lawn, as borders for drives, walks, or in front of shrubbery, and in the garden, and many varieties make beautiful bouquets for indoor use when cut. For your convenience we have specified the purpose for which each variety is best adapted as follows:

\section{(S) sunny or nearly sunny positions \\ (P) shady or semi-shady positions \\ (C) best for cut-filowers \\ (R) rock garden varieties}

AcHiLLEA-Boule de Neige. (C) (S) Very valuable for cutting or border, a dwarf form of 'The Pearl, with larger ball-shaped flowers. 20 cts. each; $\$ 2.00$ per 12 .

AGROS'IEMMA - Coronaria (S) (Rose Campion) Thrifty growing piants with silvery foliage, two to three feet in height, with a profusion of bricht crimson. Phlox-shaped flowers during June and July, 20 cts. each; $\$ 2.00$ per 12.

A.JUGA-Reptams ( $R$ ) ( $P$ ) An excellent plant for shady places, carpeting the ground under trees where grass will not grow. Extensively used in the rockery: Grows 3 to 4 inches high, bearing deep, purplish-blue flowers in May and June. 20 cts, each; $\$ 2.00$ per 12 .

ALYSSUM-Saxadile camapactum. ( $R$ ) (S) A dwalfgrowing plant, about 10 inches, well adapted for rockery or border in early summer. 20 cts. each; $\$ 2.00$ per 12

ANCHUSA-Italica Dropmore (S) A very strong growing perennial, producing immense, bianch ing spikes 4 to 5 feet high, covered in June witl pretty gentian-blue flowers about an incli acruss. $25 \mathrm{c}$ each; $\$ 2.50$ per 12.

IQUILEGIA-Colu bine (S) One of the nost beautiful old-fashioncd plants, blooming in May and June Theil delicately s ha ded graceful flowers make them indispensable for the hard garden. 20 cts. each; $\$ 2.00$ per 12 .

Cunadensis. Native. Red and yellow.

Chrysantha. Clear yellow

Caerulea. Rocky Mountain Columbine. Blue and white.

Skinneri. Yellow, with long red spurs.

scott Eliott. Long spurred Hybrids. A splendid mixture of the most delicate columbine color's.

ARMERIA ( $R$ ) (S) Dwarf plants forming evergreen tufts of bright green grass-like foliage,
from which numerous flowers appeal in compact from which numerous flowers appear in compact heads on stiff, wiry stems 9 to 12 inches high. Spring till Fall and are thrifty grower's in most any soil. Very useful as a border. 20 cts. cach, $\$ 2.00$ per 12 .

Laucheama. Lavendel-pink.

Fornosa. Blight rose.

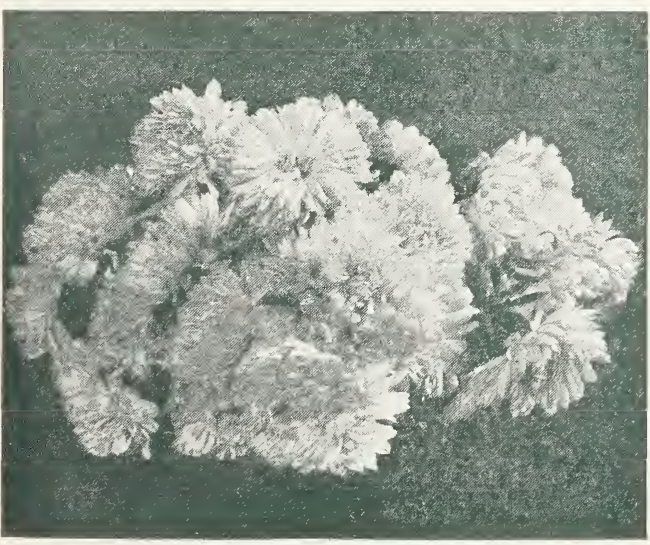

AS'IERS-IA VEN DER

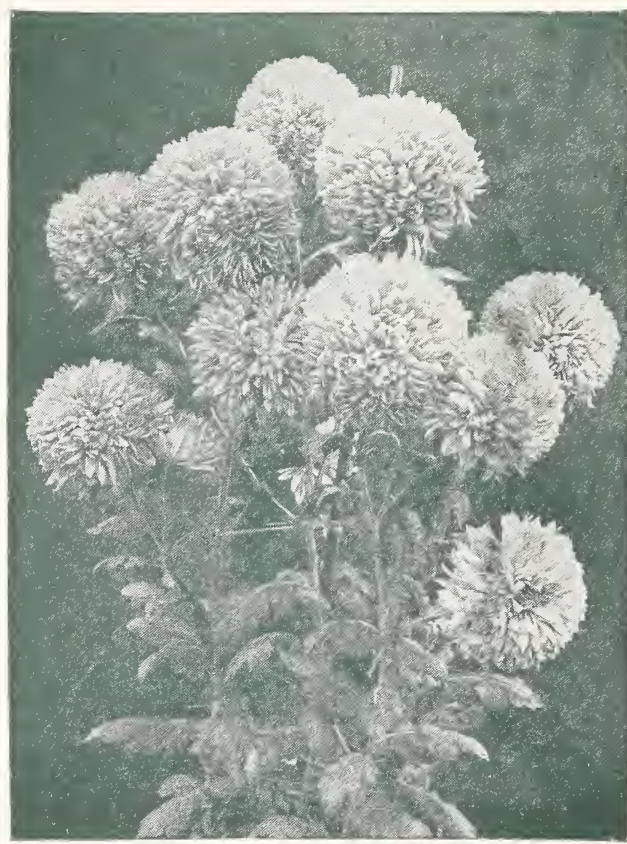

CHRYSA NTHEMUMS

AR'TEMESI A-Hactiflora (S) Deep green, finely cut foliage, with erect branching stems of fragrant cleamy white flowers in August and September. 4 to $4 \frac{1}{2}$ feet. $20 \mathrm{c}$ each; $\$ 2.00$ per 12 .

ASCLEPIAS-Tuberosa (S) A very attractive native plant, producing broad heads of bright orange height. 20 ets. each; $\$ 2.00$ per 12 .

HARDY ASTERS (S) These plants are valuable for their. wealth of bloom in early fall when the for their wealth of bloom in early fall when the each; $\$ 2.50$ per 12 .

Alondrothe, Rose. 4 feet.

Climax. Pyramidal spikes of large, light lavender blue flowers with prominent yellow center. One of the best. $5 \mathrm{ft}$

Felthan IBlue. Free flowering, sky-blue.

Mauve Cushion ( $R$ ) Dwalf growing, soft mauve, fine for late border.

Mrs. Raynor. The deepest red Aster. $3 \mathrm{ft}$

St. Egwin. Exceptionally free, pink. $2 \mathrm{ft}$.

White Climax. Pure white. $4 \mathrm{ft}$.

BAI'IISI -Australis (S) Attractive deep green foliage with spikes of deep blue flowers in June A strong grower, about $2 \mathrm{ft}$. 15 cest. each; $\$ 1.50$ per 12 .

CAMPANULA-Media Calyeanthema (S) (Cup and Saucer) Blue, rose and white. $20 \mathrm{c}$ each; $\$ 2.00$ per 12. 
CENTAUREA - Montana (S) Bears large, loosepetaled, violet-blue flowers from July to September. 2 ft. high. 15 cts each; $\$ 1.50$ per 12.

lontana Alba. White form of the above. $15 \mathrm{cts}$ each; $\$ 1.50$ per 12 .

CHIRYSANHEMUMS (C) (S) These are among the latest blooming perennials and make it possible
to keep a good assortment of colors, both for cutting and for show, right through to the end of che season. 20 cts. each; $\$ 1.75$ per 12 .

Alice Howell. Orange yellow, large.

Iutumn Glow. Rose-pink. Large.

wva. A dwarf grower, bright pink, very useful as a late border.

Fields of Snow. Pure white, tinged when old with light red. Button. Gyps Quecn. R e d d is bronze. Large.

Indian. Copper red.

Little Bob. Reddish bronze. Button.

rellow Button.

CONVALLARIA Vi a a 1 i (R) (P) (Lily of the Valley) Clumps. $35 \mathrm{c}$ each, $\$ 3.50$ per 12 .

corfors IS - Ianceoiata (C) (S) A very hardy. strong growing perennial ctbout 18 inches high, bearing a profusion of bright yellow daisy-like flowers, very usefui for cutting: By keeping old flowers cut off will bloom each; $\$ 1.50$ per 12

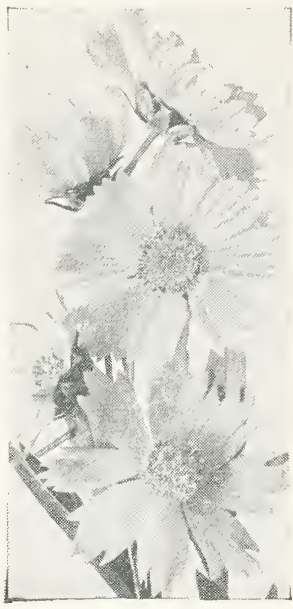

COREOPSIS
DICENTRA-Eximea ( R) (S) ( P) (Plumy Bleeding: Heart) A dwarf growing variety of Dicentra and with very attractive, finely cut foliage, bearing racemes of pretty heart-shaped pink flowers throughout the season. A desirable plant, doing well either in shade or sun. $25 \mathrm{c}$ each; $\$ 2.50$ per 12

DIGITALIS-Gloxinaeflora (C) (S) A very showy old-fashioned plant bearing immense spikes of thimble-shaped flowers during July and August. Separate colors, rose, purple, and white, 20 cts. eacin; $\$ 2.00$ per 12 .

EULALIA (S) Ornamental grasses extensively used for bedding and as specimens. Very distinctive in appearance and hold a uniform attractiveness throughout the season. $25 \mathrm{c}$ each; $\$ 2.50$ per 12 .

Gracillina Cnivitata. Long, narrow, green leaves with silver midrib. 4 to 5 feet.

Japonica Variegata. Long narrow leaves, striped green and white. 4 feet.

Zebrina. Green leaves crossed every 2 to 3 inches with broad bands of yellow. 4 to 5 feet.

EUPA'TORIUN (C) (S) Coelestinum. A dense mass of blue Ageratum-like flowers during August and September. Very useful for cutting. $2 \mathrm{ft}$. 20 cts. each; $\$ 2.00$ per 12 .

FUNIA-redia Variegata (S) A dwarf-growing plant with broad variegated green and white leaves. Unexcelled as a dwarf border plant. 20 cts. each; $\$ 2.00$ per 12

Glauca (S) A Japanese variety, with attractive bluish foliage. 40 cts. each; $\$ 4.00$ per 12 .

Lanceolata ( $P$ ) Dark, glossy green foliage. with stems of delicate lilac flowers in September. A useful shade plant. $20 \mathrm{c}$ each; $\$ 2.00$ per 12

Subcorata Grandiflora ( $P$ ) Very attractive light green foliage, bearing fragrant, white, lilyshaped flowers in August. $40 \mathrm{c}$ each: $\$ 4.00$ per i2.

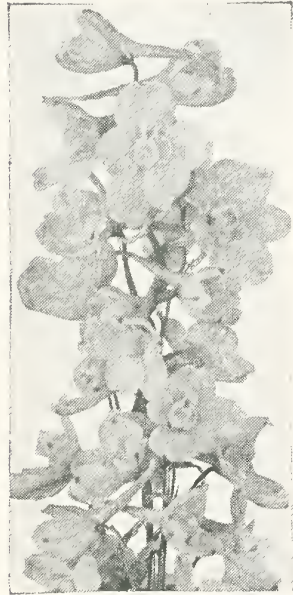

DELPHINIUM
DAISY-Shasta, A I a s $k$ a. (C) (S). L a r g e white flowers in large quantity throughout fall. Very good for cutting. $15 \mathrm{c}$ good for cutting.

JE'LPHINIUM (C) (S) A very satisfactory plant in the hardy garden, givin the hardy garden, giving shades of blue from June until frost whicl where. Also one of the most valuable and profita. ble cut-flowers. $20 \mathrm{c}$ each: $\$ 2.00$ per dozen.

Bclladonna. Tu rquo ise blue. The most continuous and profuse blooming Delphinium, bearing ing Delphinium, bearing June until frost. Twoyear-old clumps.

Bellamosm. Dark blue form of the above. Twoyear-old clumps.

English Hybrids. A marvelous assortment of all the shades of blue, flowers borne in spikes of unusual length. A very good strain with both double and single flowers. Two-year-old clumps.

DIANTHUS BARBATUS, (S) Very popular oldfashioned flowers bearing broad heads of showy per 12

\section{White Beauty.}

Johnson's Giant. The best of the Sweet Williams, buaring immense heads of flowers in a riot of color.

Latifolius Atrococeincus. (Everblooming Sweet William.) In constant bloom from early sune until frost. Flowers are brilliant crimson an double. Very showy.

Newport Pink. Deep salmon-pink.

Nigrencens. Deep velvety crimson. Dark green, thrifty foliage.
GIILARDI-Grandiftora (C) (S) This is one of the most beautiful of the perennial plants, bearing a multitude of blooms from June till frost. Petals are of orange and yellow, strikingly fringed by circles of maroon, crimson and red, witl a hard deep maroon cone for center. Will make a gorgeous display in any soil. 20 cts. each; $\$ 2.00$ per 12.

GEUM-Mrs. Bradshaw (s) Brilliant scarlet, carnation-like flowers on long slender stems from June till September. 15 inches. 20 cts, each; $\$ 2.00$ per 12 .

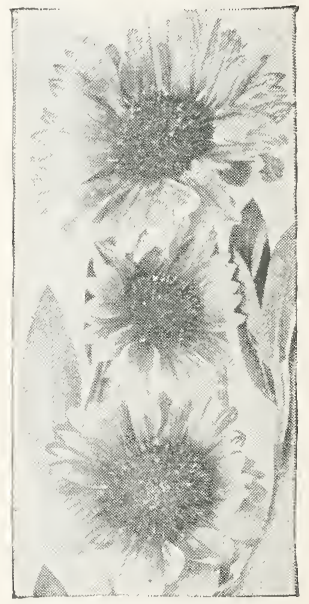

GAILLARDIA

GYPSOPHILA-Paniculata (C) (S) A dense, spreading bush, forming a mound 2 to 3 feet high, and during July and August is mass of minute white flowers, the sprays of which are very useful for cutting with other flowers. Strong 2 -year roots. 15 cts. each; $\$ 1.50$ per 12. covered with sinall old-gold bro rounded bush rich autumn shades of red and brown. A very rich autumn shades of red and brown. A very" perennial border. 20 cts. each; $\$ 2.00$ per 12.

HELIOPSIS-Pitcheriana. (C) (S) Orange-yellow, daisy-like flowers with a brown pyramidal ter. Very good for cutting. $15 \mathrm{c}$ each; $\$ 1: 15$ per 12 .

HIBISCUS-Mcehan's Marvel. (S) Red, pink and white, separate. 20 cts. each; $\$ 2.00$ per 12 .

Mixed. Each 15 cts; $\$ 1.50$ per 12
HELENIUM-Riverton Gem. (S) A very stronggrowing plant forming a large rounded busl 


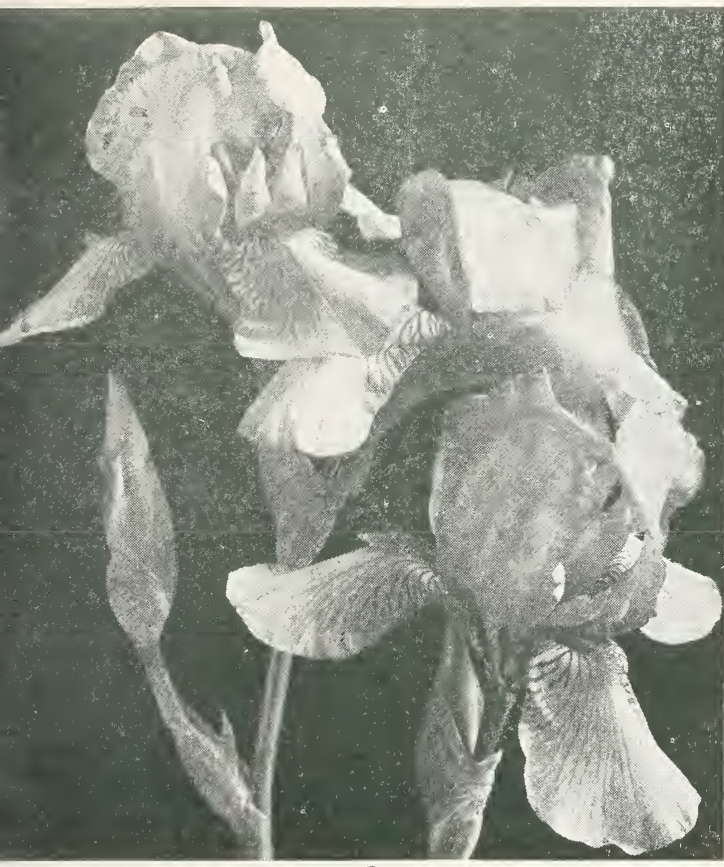

GERMAN IRIS-CELES'TE

HEMEROCALLIS-Flava. (S) (Lemon Lily.) Panicles of lemon yellow sweet-scented flowers 3 to 4 inches across. $3 \mathrm{ft}$. $20 \mathrm{cts}$, each; $\$ 2.00$ per 12 .

Dr. Regel. Deep orange-yellow flowers during May Very fragrant, and useful for cutting. $1 \frac{1}{2} \mathrm{ft} .20 \mathrm{c}$ eacli; $\$ 2.00$ per 12 .

Middendorfi. Dark green foliage, cluster's of bright yellow flowers 5 to 6 inches long. Blooms during May and June. $2 \frac{1}{2} \mathrm{ft}$. $15 \mathrm{cts}$. each; $\$ 1.50$ per 12.

'Thubergi. The latest blooming Hemerocallis, bearing funnel-shaped flowers of buttercup yellow during July. $4 \mathrm{ft} 15 \mathrm{c}$ each; $\$ 1.50$ per 12

HEPA'TICA-Triloba. (P) A native plant with low iuxuriant foliage, bearing small bright blue flowers in early spring. Very good for naturalizing or use in deep shade. $15 \mathrm{cts}$. each; $\$ 1.50$ per

HOLLYHOCK (P) Double Crimson, yellow white, maroon and pink. 20c each; $\$ 200$ per 12.

Allegheny. Mixed.

IBERIS-Sempervirens. ( $R$ ) (S) Hardy white Candytuft. Dark, shiny evergreen foliage, hidder in early spring with dense panicles of pure white flowers. A dwarf-growing plant, much used in rock gardens. 20 cts. each; $\$ 2.00$ per 12 .

IRIS GHRMANIC A (C) (S). A group of varieties valuable as cut-flower's as well as for their ornamental beauty. Our beds are fresh planted and you may be sure of getting good strong plants. 20 cts. each; $\$ 2.00$ per 12 .

Midnight. Standards and falls uniformly deepest purple.

Lohengrin. Very large flowers of one color, soft cattleya rose.

Monsignor. Standards violet. Falls crimson-purple with gleaming violet veins.

Celeste. Uniformly colored flowers of azure blue.

Her Majesty. Standards lavender-rose, falls crimson tinged with white.

Honorabilis. Standards clear yellow, falls maroon. Isoline. Standards pale lavender, falls light purple overlaid with brown. Large.

Nieblungen. Standards fawn, falls violet, very at tractive.

Pallida Mandralisca. Standards azure. Falls deep blue.

Parisiensis. A uniform deep purple, falls penciled white.

Tamerlane. Standards light blue, falls deep purple. Very luxuriant.
LAVEN1) ULA-Vera. (S) This is the true Sweet Lavender. It grows about $18 \mathrm{in}$. high and bears fragrant spikes of blue flowers during July and fragrant spikes of blue fowers during July and cts. each: $\$ 2.50$ per 12 .

IATHYRUS-Latifolius. (C) (S) Everlasting Sweet Pea,) One of the most attractive hardy climbing plants, from the standpoint of both foliage and flowers, growing 8 to $10 \mathrm{ft}$. high when trellised, flowers, growing 8 to 10 ft. high when trellised, flowers the entire season, which are excellent for cutting. Red, pink, or white. 25 cts. each; $\$ 2.50$ per 12

LINUM-Pcrennae. (Ii) (S) Light green, graceful foliage, covered with pale-blue flowers during July and August. A plant extensively used in the rockery. About 18 inches high, inclined to horizontal growth. 15 cts. each $\$ 1.50$ per 12 .

LYCHNIS-Chalcedonica. (S) Heads of brilliant scarlet bloom from late June till August. A very conspicuous plant. 20 cts. each; $\$ 2.00$ per 12 .

Viscara Splendens. ( $R$ ) Sends up spikes of bright crimson flowers about a foot high during July and August. Foliage in dense tufts, almost ever-
greer. Perhaps the brightest of the hardy perennials. 25 cts. each; $\$ 2.50$ per 12 .

MONARUA-Cambridge Scarlet. (S) Forms dense clumps, producing brilliant crimson flowers on stems 2 to 3 feet long during July and August. Foliage highly aromatic. 15 cts. each; $\$ 1.50$ per 12.

MVoso'rIS-l'alustris. ( $R$ ) (S) The true "Forgetme-not, bearing its azure-blue, yellow-centered flowers in plofusion during eally summer, and prized for its sentiment. 15 cts. each; $\$ 1.50$ per 12

PA PA V FR-Poppy. (S)

Nulicaule. (R) (Tceland Poppy.) Low tufts of light green, fern-like foliage from which spring slender leafless stems $1 \mathrm{ft}$. high, each bearing a pretty, 2 inch, saucer-shaped flower. Blooms very profusely in early summer and in a lesser degree profusely in early summer and in a lesser degree
throughout the season. Orange or white. $20 \mathrm{cts}$. each; $\$ 2.00$ per 12 .

Oriental Mixed. These are grown from the seed of the largest-flowered perennial poppies and contain a good variation of color. $25 \mathrm{cts}$. each $\$ 2.50$ per 12 .

HARDY PILOX. (S) Strong, field-grown plants

Athis. Salmon-pink. 20 cts. each; $\$ 2.00$ per 12.

8. Compte. Rich ox-blcod red. A strong luxuriant grow€r. 35 cts each; $\$ 3.50$ per 12 .

La Vague, Rosy mauve with carmine eye. 20 cts each; $\$ 2.00$ per 12 .

Miss Lingard. Pearly white with delicate lavender eye. The earliest bloomer, bearing two or three crops of flowers during the season. Free from attacks of red spider. 20 cts. each; $\$ 2.00$ per 12 .

Mrs. Jenkins. An early blooming pure white. 20 cts.. each; $\$ 2.00$ per 12 .

Mrs. Dwyer. White with large rose eye. 20 cts each, $\$ 2.00$ per 12 .

Rheinlander. Large trussed. Bright salmon-pink, large florets. 30 cts. each; $\$ 3.00$ per 12 .

Seiboldii, Light crimson. 20 cts. each; $\$ 2.00$ per 12

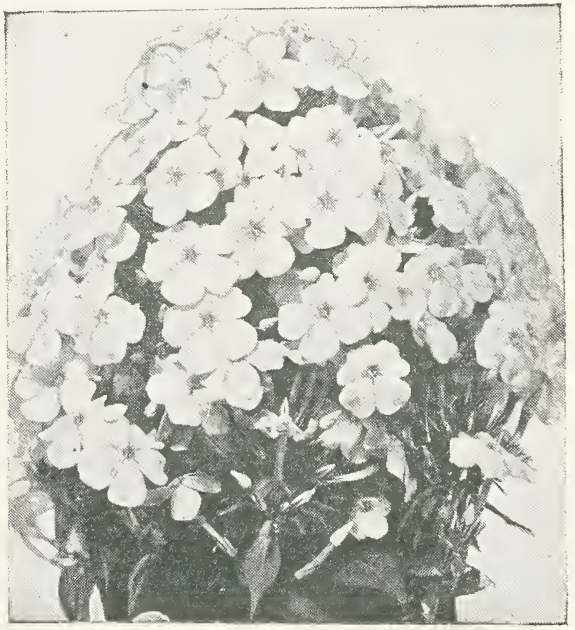

HARDY PHLOX-MISS LYVGARD 
HARDY PHLOX-Continued.

Von Lassburg: Pure white, large heads of bloom. 25 cts. each; $\$ 2.50$ per 12 .

Subulata Rosea. (R) (Moss Pink) Used extensively as a ground cover. The moss-like foliage is a as a ground cover. The moss-like foliage is a cts. each; $\$ 2.00$ per 12.

Subulata Alba. ( $R$ ) A pure white form of the above. 20 cts. each; $\$ 2.00$ per 12 .

Amoena. (R) A very useful dwarf species, excellent as a ground carpet, in the rockery, or the perennial border. It attains a height of only 3 to 4 inches, and in spring is a sheet of brishtest pink flowers. 15 cts. each; $\$ 1.50$ per 12.

PINKs. (S) These old favorites are at their best in May and June, bearing their clove-scented fowers in great profusion. They are valuable both in the hardy border and for cutting. 20 cts. each; $\$ 2.00$ per 12 .

Essex Witch. Pink, fringed flowers.

Her Majesty. Pure white.

Erfurt. Dwarf-growing, with double flowers in various showy colors.

PHISILIS-Franchetti. (C) (S) (Chinese Lanterr rlant.) This ornaniental bherry forms dense bushes about 2 . high and peal's its orange-scarlet, lantern-like fruits in decoration when dried. 20 cts. each; $\$ 2.00$ per 12 .

PIA'TYCODON-Grandiflorum. (S) Bears numerous balloon-shaped flowers constantly from July till late September. Does well in any soil. Blue or white. 15 cts. each; $\$ 1.50$ per 12 .

PRIMULA-Veris. ( R) (P) (English Cowslip.) A pleasing strain of hardy Primrose, bearing flowers in Spring in a wide range of color. It thrives best in a partially shaded, open position. in rich soil.. Equally attractive in the perennial border or rock garden. 20 cts. each; $\$ 2.00$ per 12.

PYRI'THRUM-Hybridum. (C) (S) Fine-cut, ern-like foliage, with attractive daisy-like flowers on long, graceful stems in all the shades of red and pink. Excellent for cutting. June and July. 20 cts. each; $\$ 2.00$ per 12 .

PLUMBAGO-Larpentae. (S) A highly desirable border plant. Uniform habit of growth, about 12 inches high and very compact. Bears clusters o bright cobalt biue flowers from August till frost itractively set off by the apple-green foliage. 20 ets. each: $\$ 2.00$ per 12

RUDBECINIA-Purpurea. (S) A distinctive pere n nial flowers about 4 inches across, the petals of a peculiar reddish purple, with a remarkable 1 a $r$ ge coneshaped center of brown. cts. each; $\$ 2.00$ per 12 .

Goldeu Glow. An old-fashioned favorite Thrift growing, attaining a height of from 5 to 6 ft and duces a profusion of double, colden-yellow, Cactus Dahlia-like flowers from July lia-like flowers from July to September.
$\$ 2.00$ per 12 .

SAl.IA-Azurea Graudillora. (S) A hardy species of Salvia bearing a profusion of sky-blue flowers during August and September. $A$ very graceful plant, with swaying flowers wands 3 to 4 feet high. 15 cts. each $\$ 1.50$ per 12 .

SAPONARIA-Ocymoides. ( $R$ ) (S) A very pretty dwarf creeper, covered with small bright pink flowers during Jury and August. 15 cts. each; $\$ 1.50$ per 12 .

ocymoides Alba. White form of the above. 15 cts. each: $\$ 1.50$ per 12
SEDUM (S) (Stonecrop). The dwarf varieties are excellent as rock garden plants, liking sunny positions, and the taller types make effective and unfailing color groups in the hardy bolder. These drouth-resisting plants thrive in almost any soil.

Acre. (R) (Golden Moss.) Dwarf. Much used for carpeting. Foliage green, flowers bright yellow. 20 cts. each; $\$ 2.00$ per 12 .

Glaucum. ( $R$ ) Dwarf. Bluish white foliage. Excellent for edging or rockery. 20 cts. each; $\$ 2.00$ per 12.

Stahlii. (R). Dwarf, Compact growing, with foliagc an attractive crimson in fall. 20 cts. each $\$ 2.00$ per 12 .

Spectabile. Erect. Grows 18 inches high, with broad, thick, light green leaves, and bears immense heads of attractive rose-colored flowers in August and September. 20 cts. each; $\$ 2.00$ per 12.

Spectabile Brilliant. Bright red form of the above 25 cts. each; $\$ 2.50$ per 12 .

S'IA'TCE-Latifolia. (C) (S) Grows 15 to 18 inches high with tufts of leathery leaves. Bears immense heads of very minute light blue flowers. Excellent for cutting with other flowers and if cut and dried will last for months. 25 cts. each; $\$ 2.50$ per 12 .

S'TOIESIA-Cyanea Hlue. (S) Bears freely lavender-blue fowers of centaurea shape, 4 to 5 inches across. 20 cts. each; $\$ 2.00$ per 12.

TRI'TOMA-Pfitzerii. (C) (S) An improved type of Red Hot Poker. Blooms during August and Septenber. $25 \mathrm{cts}$. each; $\$ 2.50$ per 12 .

IERONICA-Incana. (S) Silvery foliage with spikes of amethyst blue flowers about a foot high. July to August. 20 cts. each; $\$ 2.00$ per 12

Longifolia subsessilis. An attractive border plant, with rough, deep green foliage, bearing numerous spikes of pretty blue fiowers during july and August. 2 feet. 20 cts. each; $\$ 2.00$ per 12

VINCA-Minor. ( R) (P) An evergreen creeper, extensively used for ground cover in the sinade where grass will not grow. Single light blue flowers in June and July. 15 cts. each; $\$ 1.50$ per 12.

VIOLA- $(R)$ ( $P$ ) These improved forms of Viola Cornuta flowers continually from early spring till fali. While they are not as large as the Pansy their clear colors and abundant bloom are fast gaining them popularity. 15 cts. each; $\$ 1.50$ per 12

Admiration. Light blue.

Lutea splendeus. Bright yellow.

white Perfection. Clear white.

IUCCA-Filamentosa. (S) Broad, sword-like, evergreen foliage. In midsummer bears erect branching stems of pendant, creamy white bells. Equally attractive and showy as specimens or in group planting. 4 to 6 feet. Strong 2 year plants. 25 cts. each; $\$ 2.50$ per 12

Filamentosa Variegata. This plant is a variegated form of Yucca Filamentosa, and resembles it closely in form, habit and bloom, bearing its panicled, cream-colored flowers on a stiff 3 to 4 ft. stalk for the first time when the plant is 3 year old. The bayonet-like leaves are dark bronze green at center, with intermediate stripes to a broad yellow band on each edge. An outstanding plant, keeping its attractiveness the year round. Two-year plants, $\$ 1.00$ each. 


\section{To Our Friends}

CLUB ORDERS On orders of $\$ 25$ and upwards at the 100 rate regardless of quantity taken. Get your neighbors to club with you and take advantage of this offer In all cases 5 will be furnished at the 10 rate, and 50 at the 100 rate.

Terms Cash with order unless otherwise agreed order must be accompanied by one-third of the amount to guarantee acceptance.

Guarantee We guarantee all stock to be up to in good condition and well packed when it leaves our grounds. All claims for errors must be made within ten davs after receipt of goods, stating plainly cause for complaint.
Remittances Money should be sent by Post Letter, Express Money Order, or New York Draft.

Shipping We can make direct shipment on the roads, American Eork Central or Nickel Plate railParcel Post, transportation charges to be paid by customer. All heavy troes in large quantities should be sent by freight, as the charges are so much less, and our perfect packing admits of a long journey without injury to trees. Always give full and culition sponsibility ends on delive for shipping dition to the carriers. If goods suffer through delay in transit, claim should be made ‡o transportation company.

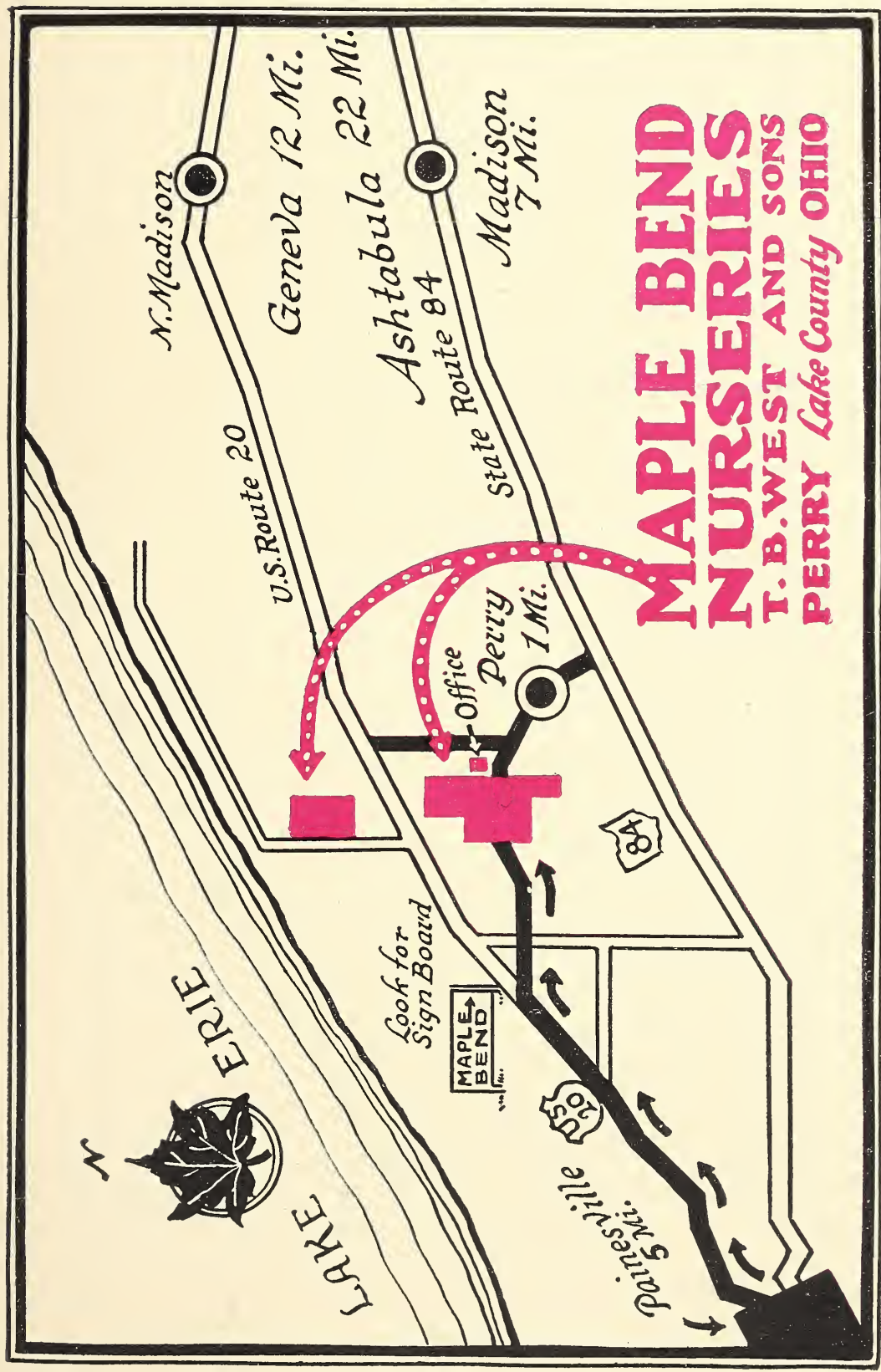

\section{Our Responsibility}

While we exercise the greatest diligence and care to have all our trees, etc., true to label, and hold ourselves in readiness on proper proof to replace all trees, etc., that may prove untrue to label free of charge or refund the amount paid, it is mutually understood and agreed to between the purchaser and ourselves, that the guarantee of genuineness shall in no case make us liable for any sum greater than that originally received for said trees, etc., that may prove untrue.

\section{Quotations}

We will be pleased to quote prices to anyone desiring different sizes of stock, or larger quantities than offered herein. In sending list state definitely the number of each variety and size wanted.

\section{Substitution}

In filling orders from this list we reserve the right, in case we are out of a variety, to substitute another of equal merit when it can be done (always labeling with the correct name), unless the party ordering says, "no substituting," in which case we will fill the order, so far as we can and return the balance.

\section{Delivery}

We will deliver by truck free of charge within 150 miles of our nursery, any order that makes a truck load.

\section{Location}

The map on this page will help you to find our nursery. We would deem it a great pleasure to show you over our nursery whenever you can pay us a visit. 


\section{It's Not a Home Until It's Planted}

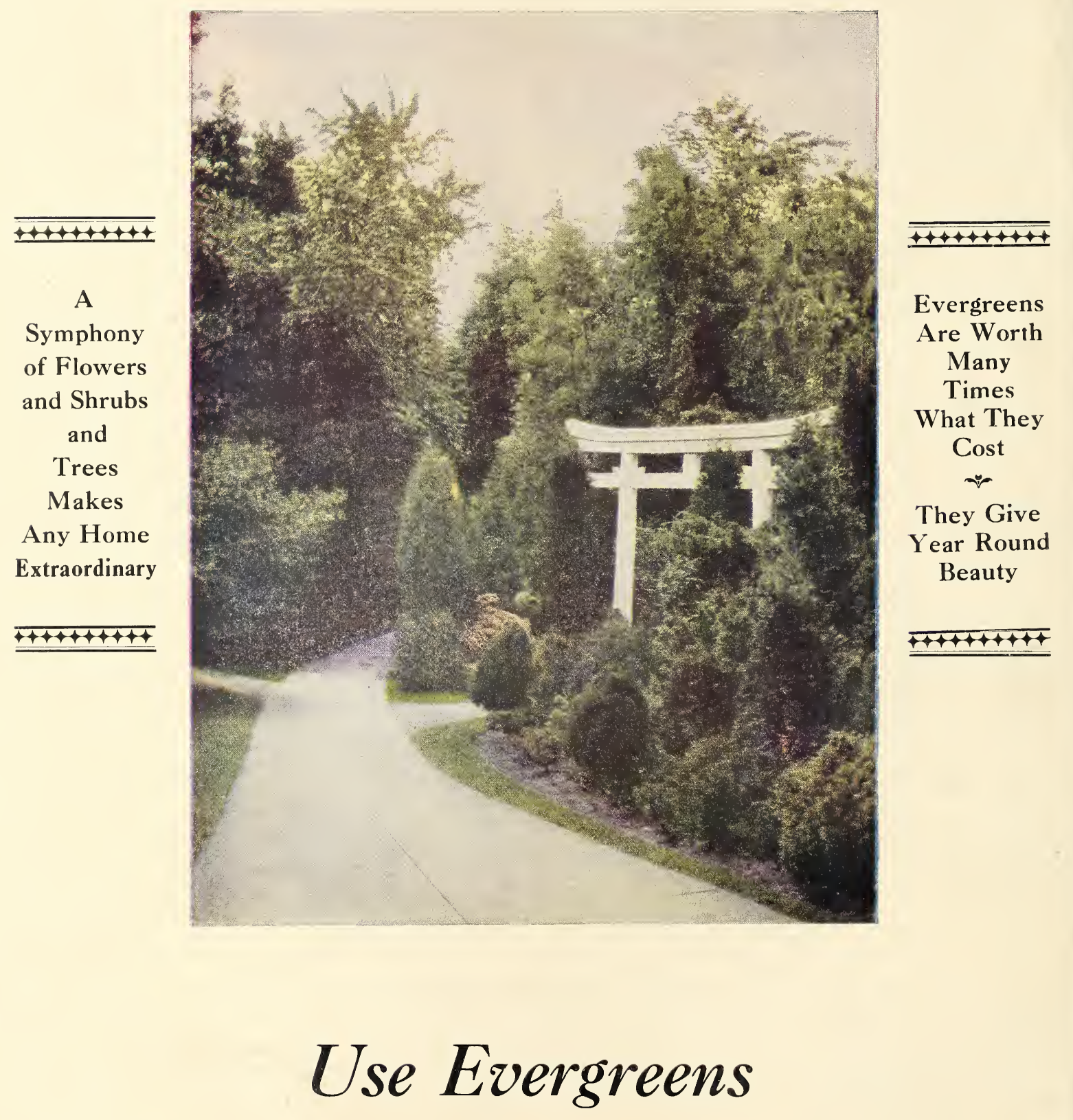

for Foundation Plantings, for Stately Individuals, for Borders and Groups, for a Japanese Garden and the Low Spreading Sorts for the Rockery 